\title{
BIRDS OF THE
}

BOSTON PUBLIC GARDEN

HORACE W. WRIGHT 


\section{Boston \\ tublic Library}

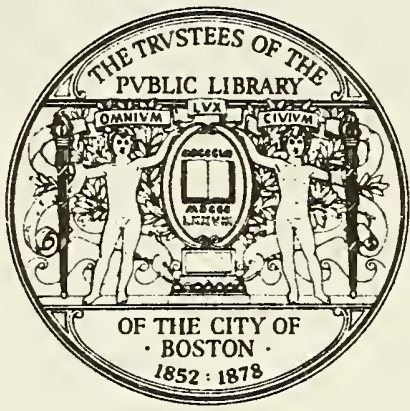

Gift of

Salem Public Library 
$\because$ W.B.CLARKE CO BOOKSELLERS \& STATIONERS

26 \& 28 TREMONT ST. \& 


Digitized by the Internet Archive in 2010 with funding from Boston Public Library 


\section{BIRDS OF THE BOSTON PUBLIC GARDEN}





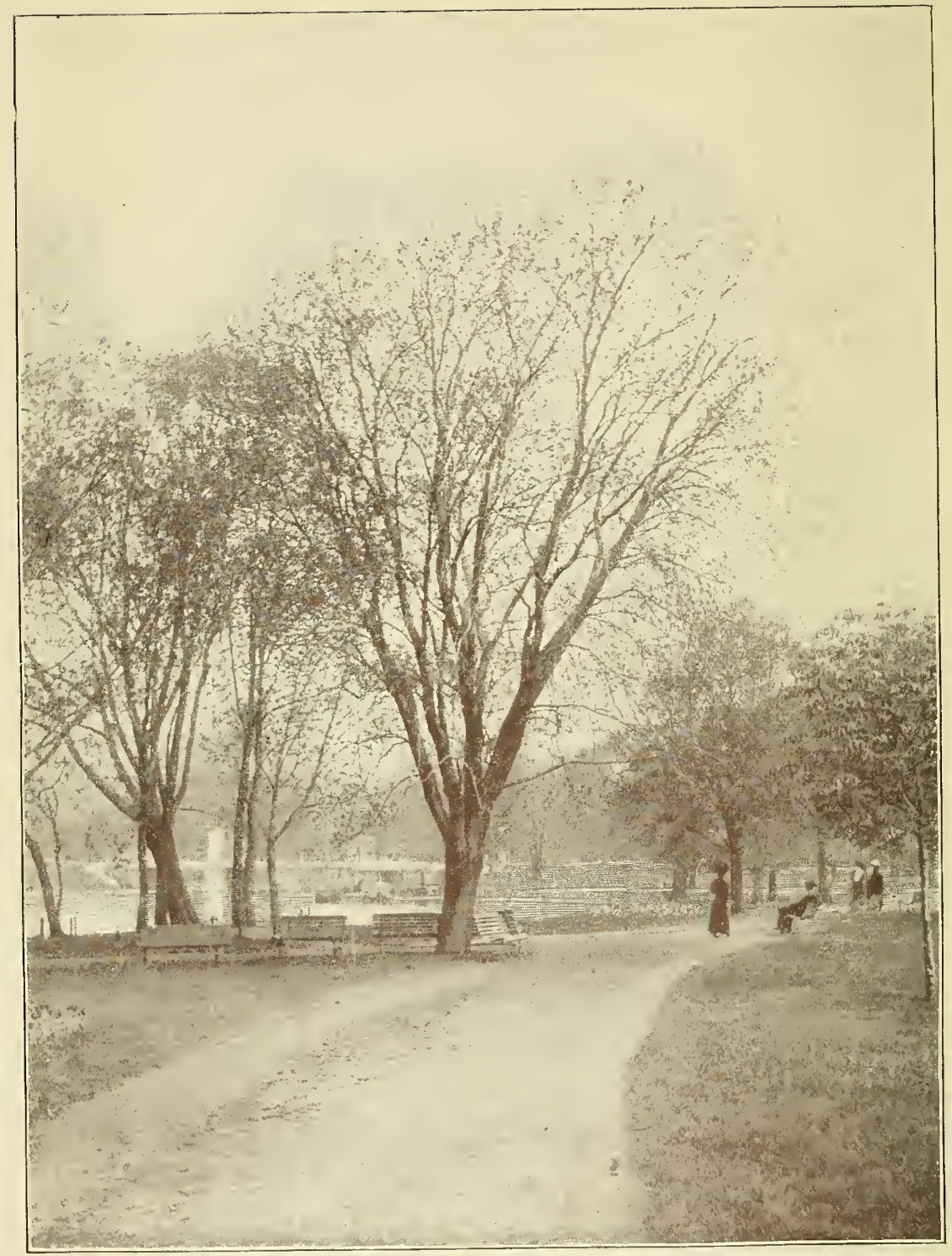

THE SILVER MAPLE 


\title{
BIRDS OF THE \\ BOSTON PUBLIC GARDEN \\ A Stuðy in sttigration
}

\author{
BY \\ HORACE WINSLOW WRIGHT \\ WITH AN INTRODUCTION BY \\ BRADFORD TORREY \\ AND \\ ILLUSTRATIONS
}

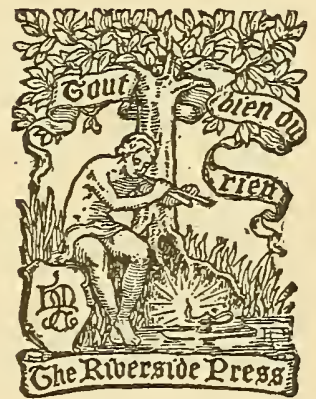

BOSTON AND NEW YORK

HOUGHTON MIFFLIN COMPANY

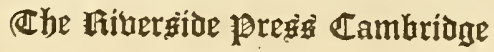

I909 
COPYRIGHT, I909, BY HORACE WINSLOW WRIGHT

ALL RIGHTS RESERVED

Published May Igog

$$
\begin{aligned}
& 4<684 \\
& \text { M4 W }
\end{aligned}
$$




\section{TO MY SISTER}

WHOSE AWAKENING TO THE INTEREST AND

PLEASURE OF BIRD OBSERVATION

WAS EARLIER THAN MY OWN

THIS LITTLE VOLUME OF RESULTS

IS AFFECTIONATELY

INSCRIBED 

"And above, in the light

Of the star-lit night,

Swift birds of passage wing their flight

Through the dewy atmosphere."

LONGFELLOW

Birds of Passage 



\section{PREFACE}

My little book, I think, will readily speak for itself, and, therefore, seems to need no prefatory word from the author. But it is pleasant to express to the reader how interesting and delightful has been the work, in the nature of pastime, done in our Public Garden during the past nine seasons, and how agreeable has been the task of arranging and analyzing the notes made there. In the work I have been encouraged and aided by many friends. Occasionally the garden-circuit has been made with eager young ornithologists who, alert and sharpeyed, have given added spirit to the morning's observation. At some other times the companionship has been with those who were earnestly bent on gathering almost their first knowledge of birds and have joined their steps with mine to see and become acquainted with a few of the more common visitants. Again, I have had the 
comradeship of friends well schooled in the field of ornithology, who have been witnesses with me of some rarer migrant warbler or sparrow. All of this companionship has been a pleasant aid and is gratefully recalled.

Those who have assisted me while I have been preparing the manuscript of this volume must have my gratitude expressed to them by name. To Messrs. Francis $\mathrm{H}$. Allen and William Brewster and Dr. Charles W. Townsend I am indebted for valuable suggestions. Mr. Glover M. Allen, secretary of the Boston Society of Natural History, has guided me through certain difficulties of nomenclature and performed for me the further service of examining the chronicled records of other observers. Mr. F. H. Allen, Mr. Eugene E. Caduc, Miss Isabel P. George, Mr. John H. Hardy, Jr., Dr. Manning K. Rand, Mr. Bradford Torrey, and Dr. C. W. Townsend have contributed names of species to the list, which otherwise it would have lacked, nine names in all. These fellow observers, and Messrs. G. M. 
Allen, Maurice C. Blake, H. A. Purdie, F. P. Spalding, and others have furnished additional information concerning certain species already listed, which is duly credited to them respectively in the notes on those species. I am also indebted to the "Ornithologist and Oölogist," to Mr. William Brewster's "Birds of the Cambridge Region," to Dr. Townsend's "Birds of Essex County," to Mr. Bradford Torrey's essay "On Boston Common," and to Mr. Justin Winsor's "Memorial History of Boston" for quotations which have been incorporated in the text.

In making my acknowledgments I cannot omit the name of one other who was much my companion in the earliest years of observation, who was also the first to suggest to me the writing of this book, and by whose loyal, inspiring friendship the flame was kept alive by which the end has been attained, Mr. Guy Emerson of Cambridge.

To my friend Mr. Bradford Torrey I am peculiarly indebted for his generous "Introductory Note" and for the pleasure of hav- 
ing his name associated with my own in this entire story of migration through the Garden and the Common, the bird-life of which he so delightfully set forth twentyfive years ago in his book of essays entitled "Birds in the Bush." I count myself happy in the association of our names as past and present students of ornithology within this public domain.

The illustrations which are presented in this volume are from photographs obtained in the month of May by my esteemed young friend Mr. Gordon Boit Wellman. The subjects were selected as illustrative of the composition of the Garden, but with more especial reference to scenes connected with the visits of some of the rarer individual birds or of collective flocks.

My obligations are also acknowledged to the Department of Public Grounds for information furnished and courtesies extended by its superintendent and his subordinates, and to members of the police force, who have often mentioned to me something of interest pertaining to the 
bird-life within the Garden and have always been civilly responsive in my communication with them.

Finally it may be said that should the records herein set forth lead others to obtain future records and continue the study of migratory life within the Garden, a fuller knowledge of its facts and a broader basis for deductions than the author's nine years' experience affords will result. The pursuit will be all pleasure and the result so much gain.

Horace W. Wright.

Boston, January 25, 1909. 



\section{INTRODUCTORY NOTE}

WHEN Mr. Wright did me the honor to propose that my name should be associated with his book, my thoughts naturally reverted to the days, now long past, when I too lived in Boston and, as the newest of beginners in bird study, - not half so fashionable an amusement then as it has since happily become,- - perambulated the Common and the Public Garden morning after morning in quest of knowledge. How pleasant those mornings were! And what wonders upon wonders I discovered! I was young then, though I had already lived nearly half the years allotted to man in that unfortunate old Hebrew verse the incessant iteration of which has made so many good people old before their time. And a happy thing it is to be young - young and ignorant. For when a man is young the world also is young; and when a man, ignorant as I was in those bright days, begins to be or- 
nithologically inclined, it is very much as if all the birds had just been created, or, at the very least, had just been let out of the ark. So I found it. Like the Lord's mercies, they were new every morning and fresh every evening. Such an additional pleasure as it was, too, to meet all those lovely strangers so near home, and in what, to my benighted apprehension, was so unpromising a place. Nobody had ever told me that a city park is one of the likeliest of all places in which to look for nocturnal birds of passage; that the nightly glare of a great city has something like the well-known fascination of a lighthouse for such travelers, especially in foggy weather. It was twenty years afterward that a friend of mine inquired of one of our most distinguished ornithologists where he should go in May to obtain sight of certain rare warblers that had hitherto eluded his ken, and was answered, much to his surprise, I think, though an undistinguished friend had already given him precisely the same advice, "Go to Central Park, New York." 
Well, the Boston Garden has no doubt grown more populous of recent years, as the city lamps have increased in number and brightness. So I shall try to believe that it may not be entirely due to Mr. Wright's superior acuteness that his Garden list is so much longer than mine ever was. I had my fun, at all events, and if he has had more, why, so much the better. That he is a sharp-eyed and competent observer, quick to see but slow to conclude, having (what is by no means the commonest thing in the world) a wholesome appreciation of the difference between guesswork and certainty, - of so much I am sure, having been more than once with him in the field. Sometimes, noting his habits of thought and speech, I have been reminded of the apostolic admonition, "Let your moderation be known unto all men " : a salutary admonition, surely, for all scientific observers, and especially for those of us who bring home no "specimens" with which to establish our testimony. I am glad that Mr. Wright's patient studies are to be published. 
They well deserve to be. And may they set many another man upon the same delightful quest that he has so profitably followed.

It was the jolliest of chronic invalids who said:-

"The world is so full of a number of things, I 'm sure we should all be as happy as kings";

which is well enough, of course, in its oldfashioned way, though I suppose it is allowable in these days to doubt whether the average king, for all the glories of his birth and state, is so very much to be envied. "Even in a palace life may be lived well." Yes, and even on a throne a man may peradventure be happy; but how much happier, did he but know it, in the saddle of a pet hobby horse, ambling at his ease, morning after morning, over the pleasant malls of a quiet city garden.

\section{BRADFORD TORREY.}

Santa Barbara, California, January 7, r909. 


\section{ILLUSTRATIONS}

The Silver Maple (Acer saccharinum), which a Blackburnian Warbler occupied during a four days' visit. . . . . . . . Frontispiece

The European White Brrch (Betula alba), and the cove of the pond round which visiting Sandpipers have walked. . . . . . . . 60

The White Willow (Salix alba), in which many Warblers congregate and sing and where the Cuckoo sat silent and inactive . . . . . 68

ThE ISLAND, which attracts the Grackles and Robins and calls to its protection many a migrant bird . . . . . . . . . . . . 94

The Basin and The Weeping Beech, where the Cape May Warbler sought and secured its bath. Under the weeping beech the Lincoln's Sparrow sometimes hides . . . . . . . . . I50

The Old Willow Group, in which many of the rarer Warblers have been seen and beneath which the Oven-bird often walks . . . . . . . I68 
The Retreat of the Yellow-Breasted Chat when shyly eluding visitors; where also late Hermit Thrushes in the autumn linger fearlessly . . I76

The European BeEch (Fagus sylvatica), in and beneath which the Thrushes seek seclusion, and through which the Blue-gray Gnatcatcher restlessly flitted . . . . . . . . . . . Ig6 


\section{BIRDS OF THE BOSTON PUBLIC GARDEN}





\section{BIRDS OF THE BOSTON PUBLIC GARDEN}

The "Memorial History of Boston," edited by Justin Winsor, contains, in the chapter entitled "The Horticulture of Boston and Vicinity," by Marshall Pinckney Wilder, the following account of the origin of the Public Garden: "The origin of this [Public Garden] may be traced to the desire of a few citizens who were interested in horticultural improvements and rural embellishments, but more especially in the establishment of a Botanic or a Public Garden, similar to those of the cities of the Old World. Among these gentlemen was Mr. Horace Gray, to whose great enterprise and indomitable perseverance we are, perhaps, more than to any other man, indebted for the original idea. . . Mr. Gray, in I839, with a few associates, obtained from the city a lease of this marginal area for a Botanic Garden, upon which a greenhouse had 
been built, while the grounds were partially laid out with a variety of ornamental trees and plants. A company was organized, of which Mr. Gray was chairman, and went zealously to work. A very large circusbuilding situated just back of the corner, west of Beacon and Charles streets, was converted into an immense conservatory for plants and birds. This had four galleries, to each of which plants were assigned according to a proper classification. It became a place of great attraction for the public until the building and the entire collection were destroyed by fire. The adjacent grounds were filled up and the garden was enlarged by the city, with the provision that it was never to be built on. In I859 these grounds became our Public Garden, and in I860 it was remodeled by laying out and planting on a definite and proper plan."

It would appear, therefore, that the inception of the Public Garden dates from I839, when a portion of its lands began to be cultivated for public use and enjoyment 
under intelligent care, and that its establishment in the entirety of its present area under the name of the Public Garden was effected in 1859 , when Hon. Frederic Walker Lincoln, Jr., was mayor of the city.

The area of the Public Garden is twentyfour acres. The area of the Common which adjoins it, separated only by a public street, is forty-eight acres. This combined domain has come to be quite within the heart of the city through its expansion westward during the last fifty years. Busy streets surround it on all sides, and substantial office buildings and stores, churches and theatres, hotels, club-houses, and residences line these streets, the State House crowning the highest point of Beacon Street. A mile eastward is the harbor-front.

For two or three miles westward the Back Bay district stretches to the town of Brookline. This region within the last half-century has been filled in, laid out in streets and avenues, and become largely built up into a new section of the city. Thus 
the Common and the Public Garden have become an isolated park-area in the midst of the city, separated from wild lands and country estates. As such it serves as an aviary for birds in their migrations.

No human power controls this aviary as a natural temporary cage to such birds as elect to occupy it for rest and desired delay in their onward flight. To such, moreover, no inducements present themselves to move out from it, for there is no inviting and suitable contiguous territory for them to move into. So, until they are inspired to proceed farther, the migrant birds which alight in this domain, a veritable oasis amid a desert of roofs, remain; with little exception remain throughout the day following the night of their flight, and to a considerable extent remain over a second day or several days, and occasionally a week or more.

While the Common must be regarded as contributing a large part, a two-thirds part indeed, to this island of rest amid human habitations and bustling activities, it has not been found that it attracts very many 
of the migrant birds to its grounds. The central portion, consisting of the Frog Pond and Monument Hill and their fringes of level land, receives most of the birds which visit the Common. But constituted, as it is, entirely of large and tall trees and lawns broken only by footpaths, being without shrubbery and low growth, it attracts few birds in respect both to number and diversity of species as compared with the Public Garden. For this reason the Garden has been the especial field of observation, while the Common has been more casually visited.

The Public Garden is surrounded by elms and maples mostly of large size, which line the streets bounding it: American elms on Beacon and Boylston streets, English elms on Arlington Street, and maples on Charles Street. These trees contribute to make the inclosure retired and seclude it from the brick and stone buildings and the streets with their busy traffic which border it. For although upon two sides trolley-cars are constantly running, and on the Boylston 
Street side is the opening of the subway with all the noise and stir accompanying the incessant entrance and exit of cars, yet these conditions prove not to be serious disadvantages in the situation.

Within its bounds the Garden contains many trees which have attained large growth, including American, English, and Dutch elms, white, weeping, and laurelleaved willows, cottonwoods, silver, sycamore, sugar, red, and Norway maples, American, European, purple-leaved, and weeping beeches, white and Lombardy poplars, lindens, horse-chestnuts, white, purpleleaved, and cut-leaved weeping birches, double-flowered hawthorns, tulip-trees, gingko trees, Kentucky coffee-trees, a red mulberry, a honey locust, a koelreuteria, a sophora, a catalpa, a European larch, and still others. Weeping elms and mountainashes, double-flowered cherries and peaches, Chinese and Parkman crabs, redbuds, magnolias in variety, spindle-trees, Siberian pea-trees, weeping sophoras, and many others too numerous to mention constitute 
the smaller tree-growth of the grounds. The trees large and small number about a thousand. Shrubs are growing in considerable variety, such as common, white, and Persian lilacs, syringas, viburnums, weigelias, forsythias, dogwoods, honeysuckles, acacias, Japanese quinces, snowberries, and rhododendrons. Several groups of dwarf evergreens are clustered at points near to the gateways; beds of hardy roses and azaleas here and there break the continuity of the lawns; and much of the iron fencing which incloses the grounds supports running vines. Beds of tulips, hyacinths, and narcissi at the opening of the spring have place in the borders of the lawns throughout. Together with this combination of tree, shrub, vine, and flowering bulb and plant in great variety, a pond covering an area of nearly four acres, located in the centre of the grounds, and a spread of green turf throughout offer an attractive restingplace to the migrant birds.

The birds which come therein are little disturbed. It may be that the presence of 
many visitors, when the early hours of the day have passed, urges them sometimes into somewhat more of retirement and requires of those that feed upon the ground more alertness and change of location; but the house sparrows seem to interfere little with the comfort of these migrant birds, although once in a while it happens that there is a severe chase of a warbler or other small bird, if it shall have offended by song or in some other way and roused the jealousy or the temper of these permanent residents.

From danger from human agencies and from their natural enemies of the wild they are free. Even cats from the surrounding dwellings come little within the inclosure and seem to offer but slight menace to the safety of the visitants. These often show very little shyness and in many instances change their location only slightly during their visit. A quiet approach and generally cautious movements on the part of the observer usually result in successful observation; and oftentimes the visitants are 
very unconcerned, even when quite close approach to them is made, and show no fear.

It was not until May of 1900 that the author of this little compendium of observation turned his steps toward the Public Garden to see what migrant bird-life there might be within. Two years previous he had taken up the pastime of becoming acquainted with the birds, and during that time he had sought the suburbs and the country by almost daily excursions from the city, and had made use of the very full advantages in summer of residence among the White Mountains of New Hampshire. It was known to him that Mr. Bradford Torrey had gathered into the initial chapter of his delightful little book entitled "Birds in the Bush," published fifteen years earlier, the results of his several years' observation on the Common and in the Garden reaching back into the seventies; but it had been assumed that such results belonged to bygone days on account of the growth of the city, and it had not been 
suggested to him as an evolving ornithologist that he might find what he was seeking, even the rarer warblers and thrushes and finches, at his very door, so to speak, or within five minutes' walk, in the centrally located Public Garden. But it happened on the ninth day of the said May that, having been driven back from a quiet town on the Sudbury River - singularly favored in the richness of its bird-life through its diversity of natural attractions - by a sudden change of weather which had replaced an early morning warmth of seventy degrees and a temperature ascending still higher in the early forenoon with a cold drizzle from the northeast, he sought in the afternoon the Public Garden for possibilities, inasmuch as the morning had indicated a full tide of migration during the previous night, and he felt disinclined to lose a day's opportunity, if haply he might find it in the Garden.

Therefore great and happy was his surprise to find that the place was well occupied with migrants and that birds were 
present which he might search for widely in the country and not find. A little brown creeper introduced him to the company of the afternoon and was the first bird of the hosts which since then have marshaled themselves before him. The rarer birds seen on this first visit were a Lincoln's sparrow and a yellow-breasted chat. There were present four or five olive-backed thrushes, a northern water-thrush, a brown thrasher, a ruby-crowned kinglet, an ovenbird, a female towhee, a catbird, more than a dozen white-throated sparrows, and nine other species of birds, making the number identified twenty species.

So fruitful in spite of the weather was this first visit that it was naturally determined to make daily visits. Thus the practice of making careful observation and taking the census of the birds present each day was begun. The observations and records have now covered nine years. Each subsequent year's observations have begun with the opening of the season in March and continued to almost or quite the end of 
May, when absence from the city for the summer has terminated the records for the season, but not until the spring migration had almost ended and there would be little more to record, yet failing to obtain the June records, such as they might be. Not half a dozen days in the eight seasons subsequent to the year of beginning have the visit and the record been omitted after the season had opened. The observations have been systematically carried on with a growing interest and a realization that the material gathered was supplying valuable data in relation to several aspects of birdmigration.

Usually two complete rounds of the Garden have been made each morning in order that the full census of the day might be obtained. The second enumeration of flocks and recording of individuals has commonly confirmed the first, or if not, such modifications in numbers have been made as the second round indicated to be a truer record. Naturally facility in accomplishing this with an approximation to accuracy was 
gradually gained. The records are, therefore, to be regarded as the result of system and thoroughness. Yet the author would not be understood as desiring the reader to think that no visitant within the Garden has escaped his notice and that he has an absolutely complete record of all of the migrant bird-life therein during the term of the nine years. In the days of May often two hours, sometimes nearly three hours, have been employed before the breakfasthour, arrival in the Garden dating from five or five-thirty o'clock. The freshness and beauty of the early morning have given added charm and zest to the pursuit definitely in mind.

Daily visits to the Garden have been resumed upon returning to the city on or before the middle of October and have been extended to the end of the season in November, with casual visits after the migration-flights had ended. No winter residents have been found in the Garden, with the single exception of the chickadee, a pair of which twice have spent the winter there. 
And visitants in the winter are very infrequent and only accidental.

The summer and earlier autumn movements of migration have not come under observation, therefore. This is a deficiency which the author sincerely regrets, but which the ordering of his year has left unsupplied.

Nearly all of the visits have been made in the early morning. Bird-observers are well aware that this is the most favorable time of day at all seasons and in all places. Especially is it of advantage to reach a central city park like the Public Garden at an early hour and make a careful round before it is much astir with human life and when the activity therein is mostly that of the birds themselves. Moreover, at such an hour the noise of the city does not much obtrude itself, and the air is comparatively quiet for the songs and the calls of the birds to be heard.

It is also true that at this time the house sparrows are less numerous and active, for they are more distributed and engaged in 
feeding and are less noisy and bent upon mischief. Later in the day, as the season advances, when throngs of people come thither to enjoy the opening blossoms, the display of flowering bulbs and the expanding leafage, it becomes less easy to move about freely, and the birds are more likely to be elusive as they shyly evade passersby.

Still, sometimes visits have been made in the forenoon and in the afternoon with good results. Especially has this been the case when the previous night has brought one of the larger migration-flights, and a second and even a third visit has been made, to obtain fuller assurance that the census of the day had been adequately taken. In some such instances a few birds have been noted in the subsequent visits which were not seen in the early morning, or may not have been present then, although it is a general truth that the birds come in the night and do not drop along through the hours of the day, and consequently that all are likely to be present in the morning 
which will be within the Garden on that day.

In evidence of night migration is the repeated fact that, when at the close of the day a survey of the grounds has revealed the bird-life which is present, the round the next morning at the opening of the day shows the presence of birds not present the evening previous, - sometimes a host, but, whether many or few, it is clear that they have come in the night and are beginning the day in this new sojourning-place. Moreover, the chips and tseets of passing small birds may be heard on quiet evenings in migration time by sensitive listeners. And keepers of lighthouses testify to the flights of birds by night, being witnesses of their striking against the lighted lanterns.

Sometimes there is a very varied and large collection of migrants in the Garden when the country is not found to be so well occupied. This suggests that the bright lights of the city attract the birds in their onward flight by night and induce many to stop, thus securing to an area like the Gar- 
den with its attractions of varied growth and water under the lights a larger share of migrants than a similar acreage in the country is wont to receive.

It has been already remarked that there is no contiguous territory for the visitants to move into. So, once in the Garden, they with few exceptions remain throughout the day, thus securing to visitors later in the day fair chances to find them and observe them. Some birds choose to stay two, three, or more days.

Some species, for instance, the bluebird, the cedar waxwing, and the sandpiper, make a hasty visit after the day is well opened, flying in for a brief call, it may be, and rising on wing and going on again. It is well known that the bluebird migrates in this way by day. The short calls which occasional sandpipers and flocks of cedar waxwings and some flocks of robins make indicate that the same is also true of these species.

The period of migration covered by the species which are in the habit of visiting 
the Garden is shown under the discussion of the species in the annotated list which follows. A long period of migration is especially characteristic of some of the species which belong to the sparrow family. No one of these nests in the Garden or on the Common, yet it will be seen that there are not a few very late arriving individuals belonging to species which appear in March and early April, indicating that some individuals of those species which early reach their nesting haunts delay their coming very much for some reason and arrive with the warblers and other later migrants in midMay.

In regard to the long-extended migration of certain species, there is reason for thinking that the earliest arriving birds, belonging to species which nest in Massachusetts as well as in northern New England and farther north, are summer resident birds, and that the later arriving visitants are birds which will proceed beyond the confines of the State to breed. Thus the very late savanna sparrows, song sparrows, swamp 
sparrows, and other sparrow visitants within the Garden, which come, as they do year by year, in the larger migratory flights with the warblers and thrushes in the middle and even later portion of May, are likely to be on their way with these more northern-nesting birds to points far beyond, while in the case of a few very early arriving birds, as hermit thrushes, for example, it is thought that they may very likely be the summer resident birds of the State. This in its entirety is Mr. William Brewster's view. This view explains, perhaps, the fact of the very long-drawn-out period of migration which the records indicate is common in the case of the above-named sparrows and occurs in the case of the hermit thrush also, but with this difference, that with the latter species the few visitants are the early birds and with the former the few visitants are the late birds.

But not only does it appear that the earlier arriving visitants in the Garden may be summer resident birds of the State and the later arriving birds be migrants on their 
way farther north; the records indicate also that in general the summer resident birds have arrived in their haunts in the suburbs and neighboring country some days earlier than any individuals of the respective species have shown themselves in the Garden. Thus, if we make use of the dates of usual arrival of species in this neighborhood, as given in Mr. Brewster's "Birds of the Cambridge Region," we find, for example, that in the case of twenty common resident species, selected for comparison, the first individuals in the series of years have arrived in the Garden from three to eight days later than in the surrounding country and that the range of first arrival of each of these species in the nine years has been from three to nineteen days later. The twenty examples will be given : kingbird arrives from four to fifteen days later; phœbe from four to twelve days later; least flycatcher from eight to fifteen days; vesper sparrow from five to eighteen days; chipping sparrow from six to seventeen days; towhee from eight to fifteen days; scarlet 
tanager from four to twelve days; red-eyed vireo from five to thirteen days; warbling vireo from four to nineteen days; black and white warbler from five to seventeen days; Nashville warbler from seven to nine days; yellow warbler from six to nine days; chestnut-sided warbler from four to nine days; black-throated green warbler from six to eighteen days; oven-bird from three to eight days; Maryland yellow-throat from four to nine days; American redstart from four to ten days; catbird from six to eight days; brown thrasher from five to ten days; bluebird from eight to fifteen days. The testimony of the Garden seems, therefore, to substantiate very strongly Mr. Brewster's belief that in general the earliest arriving birds are summer residents and that the later arriving birds are migrants bound farther north.

The summer absence of the author leaves in some measure of uncertainty the matter of what species nest in the Garden and on the Common. The regular nesting of three summer resident species has been an estab- 
lished fact year by year, evident in May, namely, the bronzed grackle, the Baltimore oriole, and the robin. It may be that the red-eyed vireo or the warbling vireo, the redstart or the least flycatcher has been sometimes represented by a pair of breeding birds. Mr. Torrey speaks of some of these species as being summer resident birds on the Common twenty-five or thirty years ago. A vireo's nest on the Common, well preserved in the late fall, three or four years ago indicated that a pair either of redeyed or warbling vireos had nested there, and the singing of a redstart on the Common during June in a recent summer, upon the testimony of a friend, points to the nesting of a pair of that species there. Information has also been received that in the summer of 1907 a pair of flickers nested on the Common and reared a brood of young, and also that two flickers were occasionally seen there throughout the summer of I908. The careful elimination of dead branches from the trees and the closing up of all holes resulting from decay, 
done in the furtherance of good growth and longevity, constitute these grounds, however, not a favorable place for nesting by our resident woodpeckers. Nests of breeding species other than the robin, the grackle, . and the oriole have rarely been seen in the Garden when the leaves fall in autumn. So the nesting of other than the three species named would seem to be incidental and very infrequent.

There are usually one or two exceptionally large flights of migrant birds, comprehensive in the number of species joined together, to the Garden each season. These are coincident with a pronounced warm wave coming in the middle of the month of May. In this part of the month, on a warm morning following a night of high temperature, a number of newly arrived birds will be noted at once upon entering the grounds. As advance is made, the promise of many migrants is found to be fulfilled, and interest in identification reaches an eager pitch. If, as sometimes happens, a sudden change of weather comes, and easterly conditions, 
with or without rain, accompanied by much lower temperatures, succeed within a few hours, the host of migrants remains with nearly unbroken ranks until the untoward conditions have passed and clear skies and a rising temperature induce a further flight northward. They are notable days when there is such a combination of conditions, for the number of migrants and the diversity of species are likely to be large, and the delay may continue for three or four days.

It has not been found that the migrant birds arrive every night, and that, therefore, the birds of yesterday are replaced with other birds of to-day, limiting as a rule the stay of the visitants to a single day. The indications all point to the opposite idea, namely, that there are occasional large migratory flights; that birds coming in these large movements remain to a considerable extent to a second day, and some of them during several days; that a species may have no representatives present after several or many individuals have come and passed; that then a new representation ar- 
rives in another general migratory flight. The arrivals of birds of any species are thus periodical rather than regular nightly during the migration-period of the species. Location and number of birds constituting the flocks present, both of which data prove in very many instances to be quite fixed factors, experience has shown, serve as bases for concluding that the rule is periodicity of arrival and not daily regularity.

It has been found, also, that in an aviary such as the Public Garden provides the birds may be discovered and identified successfully under rainy conditions, when an umbrella is required to save the observer from a drenching and keep the field-glasses clear for use. Such a day was May I9, I900. During the whole forenoon, when workmen were obliged to leave their work on account of the steady fall of rain and only those who needed to pass through the Garden moved on its paths, the hunt was successfully pursued. Thirty species of migrant birds were recorded, while the number of 
individuals was fifty-six, including thirtythree warblers of sixteen different species. The list may be of interest as furnishing precisely the names of the birds which were present and their respective numbers as recorded on this rainy day: one chimney swift, one wood pewee, one least flycatcher, two white-throated sparrows, one Lincoln's sparrow, one swamp sparrow, one male scarlet tanager, one barn swallow, one redeyed vireo, two warbling vireos, one black and white warbler, one golden-winged warbler, three northern parula warblers, two yellow warblers, one male black-throated blue warbler, one magnolia warbler, one chestnut-sided warbler, five black-poll warblers, one male Blackburnian warbler, one oven-bird, four northern water-thrushes, five Maryland yellow-throats, one yellowbreasted chat, two Wilson's warblers, two Canadian warblers, two redstarts, one catbird, two Wilson's thrushes, two graycheeked thrushes, and six olive-backed thrushes.

Four days later, in sunshine and warmth, 
on the ebb of the tide of migration for the season, twenty-two species of migrant birds were recorded and forty-nine individuals were enrolled, including thirty-two warblers of fifteen different species. Again the definite list may be of interest as showing the migrants in another wave of migration: four chimney swifts, one Lincoln's sparrow, one swamp sparrow, four male and one female scarlet tanagers, two warbling vireos, one northern parula warbler, two yellow warblers, one female black-throated blue warbler, four magnolia warblers, two chestnut-sided warblers, one male baybreasted warbler, five black-poll warblers, one male Blackburnian warbler, one prairie warbler, one northern water-thrush, six Maryland yellow-throats, one yellowbreasted chat, two Wilson's warblers, two Canadian warblers, two redstarts, one catbird, and three gray-cheeked thrushes. Some of these birds had remained from the nineteenth day, but many were new arrivals.

The seasons of I90I, I902, and I903 fur- 
nished no daily records as large as those given above, thereby indicating the year I900 to have been one of the exceptional years in respect to the number of migrant birds passing through the Garden.

Some other notable days in the last five years have furnished comprehensive lists. These follow.

On May 20, I904, the record day of the season, twenty-three species of migrant birds were present and forty-seven individuals were enrolled, including thirty-three warblers of twelve different species. The list was: one swift, one purple finch, two whitethroated sparrows, one song sparrow, one Lincoln's sparrow, two swamp sparrows, one female towhee, one female black and white warbler, one Nashville warbler, one northern parula warbler, four myrtle warblers, three magnolia warblers, two blackpoll warblers, two black-throated green warblers, two oven-birds, three northern water-thrushes, seven Maryland yellowthroats, six Wilson's warblers, one Canadian warbler, one catbird, one brown thrasher, 
two Wilson's thrushes, and one olive-backed thrush.

In 1905 the most memorable day fell on May I6, when thirty-eight species of migrant birds were recorded and ninety individuals were enrolled, including thirtyseven warblers of eighteen different species. The list was: one swift, two kingbirds, one wood pewee, one least flycatcher, two white-crowned sparrows, four whitethroated sparrows, one field sparrow, one swamp sparrow, one male rose-breasted grosbeak, two scarlet tanagers, male and female, four cliff swallows, fifteen barn swallows, one bank swallow, one red-eyed vireo, one yellow-throated vireo, one blueheaded vireo, three black and white warblers, one Nashville warbler, one Tennessee warbler, two northern parula warblers, three yellow warblers, one male blackthroated blue warbler, three myrtle warblers, two magnolia warblers, one chestnut-sided warbler, two black-poll warblers, one black-throated green warbler, three oven-birds, three northern water-thrushes, 
four Maryland yellow-throats, one yellowbreasted chat, two Wilson's warblers, three Canadian warblers, one redstart, four catbirds, three Wilson's thrushes, six olivebacked thrushes, and one female bluebird. The following day, whereas some of the other birds had passed on, the warblers remained with slight variations in numbers. Both of the days were clouded, with easterly winds and a temperature of forty-eight degrees.

In 1906 the maximum record was made on May 19, a comparatively small maximum of forty migrant birds of twenty-two species, of which twenty-nine birds were warblers of fifteen different species. The list was: one northern flicker, one swift, three female white-throated sparrows, one rose-breasted grosbeak, two male scarlet tanagers, two warbling vireos, three northern parula warblers, one yellow warbler, one male black-throated blue warbler, three myrtle warblers, three magnolia warblers, one female chestnut-sided warbler, two black-poll warblers, one male Black- 
burnian warbler, one male black-throated green warbler, three oven-birds, one northern water-thrush, one female Maryland yellow-throat, two Wilson's warblers, two Canadian warblers, four redstarts, and one olive-backed thrush.

In 1907 a large migration-flight occurred on May I4, when twenty-eight species were recorded and seventy-six individuals were enrolled, including twenty-four warblers of ten different species. The list was: one northern flicker, four chimney swifts, one least flycatcher, one blue jay, one bobolink, one red-winged blackbird, one purple finch, one savanna sparrow, thirteen whitethroated sparrows, two field sparrows, four swamp sparrows, six towhees, two black and white warblers, one Nashville warbler, two northern parula warblers, five yellow warblers, one myrtle warbler, one magnolia warbler, one chestnut-sided warbler, five oven-birds, five Maryland yellow-throats, one redstart, three catbirds, six brown thrashers, one house wren, one wood thrush, three Wilson's thrushes, and two hermit 
thrushes. The list indicates the lateness of arrival of some sparrows and the presence of a blue jay which was changing its location in the middle of May. The very unusual visitants a house wren and a bobolink had been drawn into this company, and a red-winged blackbird had joined it. Two belated hermit thrushes were moving on toward their summer homes at the same time with a wood thrush.

But on May I9 of the same year all previous records were broken in respect to the number of migrants, when one hundred and twenty-two migrant birds of thirtythree different species were recorded, and of these, seventy-four birds were warblers of sixteen different species, namely, three black and white, male and female, one Nashville, thirteen parula, male and female, two male yellow, one male black-throated blue, seven myrtle, male and female, ten magnolia, male and female, six chestnut-sided, male and female, one male black-poll, one male Blackburnian, four black-throated green, one oven-bird, three northern wa- 
ter-thrushes, six male Maryland yellowthroats, ten Wilson's, male and female, and five redstarts. The other species present were a yellow-billed cuckoo in song, four swifts, a kingbird, a wood pewee, a least flycatcher, a blue jay, two purple finches, eleven white-throated sparrows, a Lincoln's sparrow, two female towhees, a scarlet tanager in song, a red-eyed vireo, a blueheaded vireo, thirteen catbirds, five brown thrashers, a Wilson's thrush, and an olivebacked thrush. It will be seen that again a blue jay was present, while none had been noted in the four intervening days. This day was very warm, with light westerly winds, and attained a maximum temperature of $82^{\circ}$. It followed a fair and warm day of $70^{\circ}$ maximum temperature, with light southwesterly winds, conditions most favorable for a large flight of migratory birds.

The following day, the twentieth, became rainy, with somewhat lower temperature. Some of the birds of the preceding day had gone, but others had arrived. On 
the succeeding days, May 2I, 22, and 23, the records were also quite large, these being fair days, with a maximum temperature of about $60^{\circ}$ and westerly winds and a minimum temperature of about $42^{\circ}$, conditions calculated to hold the visitants back from hastening farther north. On May 2I sixty migrants were recorded, of which forty-one were warblers. On May 22 fiftyseven migrants were recorded, of which thirty-nine were warblers. On May 23 forty-three migrants were recorded, of which twenty-three were warblers. The numbers of migrants daily thereafter during the remainder of the month were comparatively small. But the year 1907 surpassed all previous years, except I905, in the number of migrant birds which passed through the Garden.

In 1908 by far the largest migratory flight came on May I2, when there were one hundred and thirty-seven migrant birds in the Garden and fifty others were recorded on the Common, surpassing the record-day of 1907 . The preceding day and 
night had been warm, with southwesterly breezes, the temperature rising to $78^{\circ}$ and falling in the night not below $66^{\circ}$. As soon as the eyes and ears were opened to the outer world, it was apparent that the migrant birds were very numerous. The chips of warblers were heard in Louisburg Square and among the trees of Mt. Vernon and Chestnut streets on the way to the Common, and there sparrows and warblers were present in unwonted numbers about Monument Hill and in the trees which cluster near the flagstaff. As is usual, in passing to the Garden, it proved that there lay the chief centre of interest by reason of the many species present. The list for the day was: one least flycatcher, one purple finch, one pine siskin, nine white-crowned sparrows, fifty white-throated sparrows (by estimate), one chipping sparrow, one Lincoln's sparrow, one swamp sparrow, five towhees, one rose-breasted grosbeak, and the following warblers: two black and white, three northern parula, two yellow, three blackthroated blue, three myrtle, three magnolia, 
one Blackburnian, eight oven-birds, five northern water-thrushes, seven Maryland yellow-throats, one yellow-breasted chat, two Wilson's, and three redstarts; nine catbirds, three brown thrashers, two Wilson's thrushes, three olive-backed thrushes, and five hermit thrushes. The collection aggregated twenty-eight species, of which thirteen species were warblers embracing forty-three individuals. It will be seen that the percentage of warblers in this flight was small in comparison with what it is in the case of flights which occur upon days later in May.

In the days succeeding the twelfth day, the numbers of migrants were small until the morning of the twenty-fourth day. Indeed, upon the two days immediately preceding the twenty-fourth day, the records show that no migrant was present in the Garden. This condition was unprecedented in this part of May. Therefore the migrants present on the twenty-fourth day were all newly arrived birds, without an exception. They were sixty-four in number and of 
twenty-nine species; forty-five of them were warblers of sixteen different species. Again the conditions of weather were favorable for a notable flight, as they had been on the occasion twelve days previous. The list for the day was: one nighthawk, one hummingbird, two wood pewees, one yellow-bellied flycatcher, two least flycatchers, one American goldfinch, two red-eyed vireos, one male scarlet tanager, one Tennessee warbler, one northern parula warbler, four yellow warblers, one male blackthroated blue warbler, one female myrtle warbler, three magnolia warblers, one male chestnut-sided warbler, four black-poll warblers, two Blackburnian warblers, male and female, one male black-throated green warbler, one oven-bird, six Maryland yellow-throats, three northern water-thrushes, four Wilson's warblers, six Canadian warblers, six redstarts, three catbirds, two Wilson's thrushes, two gray-cheeked thrushes, and one olive-backed thrush. It will be observed that no member of the sparrow family was present except a roaming gold- 
finch and that the warblers constituted over seventy-one per cent of the flock. Nearly all of these migrants departed the following night, and then the numbers of visitants present were comparatively small to the end of the month.

These nine lists have been given in the thought that they may serve for comparison in succeeding years by observers who may be making up the census of the migrant birds in these larger migratory flights which occur year by year. They will serve also to show whether in the years to come the flights are larger or smaller or average about the same in a longer series of years. It is of interest that the figures show that in the last two years the largest flights in the series of nine years have occurred.

In presenting exact daily records it must not be supposed that the compiler thinks that he has been able to record every migrant which day by day may have visited the Garden. But his enrollment has proceeded with system and been done with a view to its being thorough and as nearly 
accurate as carefulness and concentration of purpose could attain.

The years may be compared as to the number of species recorded in each spring migration. In 1900, observation not beginning until May 9, fifty species were recorded; in I90I, fifty-two species; in I902, sixty-one species; in I903, sixty-one species ; in I904, fifty-five species; in 1905, eighty species; in 1906, sixty-two species; in 1907 , seventy-four species; and in I908, eighty species.

The seasons may also be compared in respect to the number of individual birds which sought rest in the Garden. The figures for comparison are obtained from the sum of the daily censuses, and do not take into consideration the fact that many of the visitants remain to a second day and some for several days. The seasons may be regarded as averaging alike in this respect. If we take the fifteen days of May between the ninth and the twenty-third days, both inclusive, which was the entire period of observation in I900, we obtain these aggre- 
gates: in I900, 528 migrants; in I90I, I6I migrants; in I902, 347 migrants; in 1903, I76 migrants; in I904, I64 migrants; in I905, 60I migrants; in I906, 255 migrants; in 1907,668 migrants; in $1908,360 \mathrm{mi}-$ grants.

If the whole month of May be regarded, or indeed the entire spring season, the years remain relatively the same. These figures indicate a considerable difference in the seasons and show that I900, I905, and 1907 were seasons when the migrating birds were numerous in the Garden, while in the seasons of I90I, I903, and I904 the birds were few, and that the seasons of I902, I906, and I908 were intermediate between conditions of abundance and scarcity. These variations may be due to weather conditions and other natural causes, such as might be expected to have their influence in determining the exact pathway of the birds and their choice of the Garden as a resting-spot. Or the variations may be due in some degree to destruction of bird-life by storms or other hostile agencies, which have deci- 
mated their numbers during their winter sojourn in the south or on their way northward. But if such be the case, it is very reassuring to find that a year of abundance again follows a year or two of scant numbers, as the figures show, and that two of the last four years have been seasons of greatest abundance. If it be inquired whether this does not indicate that the migrating birds have been making fuller use of the Garden as a way station, it will have to be answered that the year 1900 was a year of almost as great abundance as the years 1905 and 1907 and may in reality have been fully the equal of these more recent years, since it must be borne in mind that the powers of observation of the recorder have become more keen by training, and the search made day by day has been more exhaustive than in that first year of observation. So there is some basis for an impression that the season of I900 may have equaled any subsequent season in respect to the use the migrant birds made of the Garden. How many years previous 
to the year I900 the Garden may have been an important way station can only be conjectured, as the area was filled in and laid out as a Public Garden only fifty years ago, the land being reclaimed from the flats of the Charles River, and the growth of the trees and its development into the attractive garden that it is have been slowly going forward in the intervening years.

Mr. Torrey in the seventies and eighties of the last century found many migrant birds present and recorded the names of sixtyfive North American birds which he had seen on the Common and in the Garden. Of their numbers in his years of observation he says in his essay "On Boston Common": "Now it is only a straggler or two; now a considerable flock of some one species; and now a miscellaneous collection of perhaps a dozen sorts." Again: "During every migration large numbers of warblers visit us"; and he names twelve species, adding, "No doubt the list is far from complete, as, of course, I have not used either glass or gun; and without one or the other of 
these aids the observer must be content to let many of these small, treetop haunting birds pass unidentified."

But however it may have been in the past, it is a pleasant thought to bird-lovers that now, as the most recent years indicate, the migrating birds are fully availing of the grateful advantages of the Garden for a pause in their long northward journeys, and are affording ample present opportunity to all who will to see them, to hear them sing, and in a measure to become acquainted with them, as far as this may be realized away from their actual nesting-places, where only the family life brings out all their specific characteristics and inspires whole-hearted song.

As regards the dates of the larger migration-flights in May, the records show that one occurred on the first day in 1907; on the third day in I905; on the seventh day in I9OI and I905; on the ninth day in 1900 and 1902; on the tenth day in 1907 and I908; on the twelfth day in I90I, I905, and I908; on the thirteenth day in I900, I906, 
and 1907; on the fourteenth day in 1907; on the fifteenth day in 1900 and 1905 ; on the sixteenth day in 1905 and 1906 ; on the seventeenth day in 1902, 1905, and 1908; on the eighteenth day in 1900 and 1907 ; on the nineteenth day in 1906 and 1907; on the twentieth day in 1903 and I904; on the twenty-second day in I90I, I902, and 1903 ; on the twenty-third day in 1900 ; on the twenty-fourth day in 1908, a notable flight into the Garden, following upon an entire absence of migrants the two previous days and the presence of but three migrants in the two days next preceding; on the twenty-fifth day in 1904 and 1906; on the twenty-eighth day in 1907.

On the twelfth day of May in 1908 the largest number of visitants was present in the Garden which had been noted in the series of years; one hundred and thirtyseven (twenty-eight species) were recorded. On the Common the same day fifty more were numbered. The next largest record was on May 19, 1907, when one hundred and twenty-two migrant birds (thirty-three 
species) were recorded. The third largest record was of ninety migrants (thirtyeight species) present on May 16, I905. The fourth largest record was of eightyone migrants (fifteen species, there being forty-five white-throated sparrows present) on May 3, 1905. The fifth largest record was of seventy-six migrants (twenty-eight species) on May I4, I907. The sixth largest record was of sixty-four migrants (twentynine species) on May 24, I908.

In the eight seasons, namely, I90I-I908, the first migrant or migrants have appeared respectively on the following dates: in I90I, on March 24, song sparrow and robin; in I902, on March I3, flicker, junco, song sparrow, hermit thrush, and robin; in 1903 on March 6, song sparrow, a single bird; in I904, on March 24, bronzed grackle, junco, song sparrow, and robin; in 1905 , on March I8, flicker, bronzed grackle, song sparrow, and robin; in I906, on March I I, bronzed grackle, two birds; in 1907, on March 17 , junco and song sparrow ; in 1908, on March 
I2, bronzed grackle, song sparrow, and robin. It will appear that the song sparrow was the first or among the first migrants in all of these years except r906, when, after the arrival of the grackles, daily low temperatures and snowstorms held back the opening of the season to March 28, on which day a song sparrow and a robin joined the two grackles which were already present.

Some attention has been given to the subject whether the latest migrants are usually females, the male birds having preceded them. There is no clear evidence that such is the case. Often the last individuals of a species present have been singing males. Not infrequently the last bird or birds have been females. Sometimes the latest record of the species for the season shows that both male and female birds were present and departed together. It is generally the case, however, particularly in respect to the warblers, that fullplumaged male birds precede the more dull-colored female birds in time of arrival by a day or two or more. And if a warbler 
of any species be seen on an especially early date, it is almost without exception a male bird which has pushed ahead and perhaps broken the local record.

In the annotated list which follows it will be found that occasional reference is made to the continuance of stay of individuals in the Garden. In the case of the rarer migrants this can be determined with little liability of error; as, when a Cape May warbler is present during four days, it is reasonably certain that it is one and the same bird, if the bird present each day differs in no discernible particular from the bird first seen. Usually in these cases additional credibility to the testimony is furnished by the fact that quite commonly migrants remain in the section of the grounds where they were discovered or to which they soon by choice move, or, if departing therefrom, show a strong disposition to return to it and spend much of their time within it, feeling wonted therein, much as when they have chosen a spot on their breeding-grounds for their nest and 
circulate rather closely about its immediate vicinity.

The notes given under the various species in the list which follows will show how frequently this has been true in instances of extended stay. The instances which are not specially mentioned are very numerous. A few examples may be cited here. A Blackburnian warbler almost confined himself to one silver maple during a four days' stay. A Cape May warbler was found usually in the same quarter of the Garden during a four days' stay. An oven-bird walked back and forth near a section of the Arlington Street fence during a seven days' stay. A tailless brown thrasher; which finally departed with other thrashers, had occupied the same section during a seven days' stay. A late-coming, dull-colored hermit thrush was daily seen in May within one small area during a nine days' stay. Other examples might be given of the attachment of visitants to a very limited area during even an extended stay. The law very widely applies, and general conformity to it on the 
part of visiting birds assists an observer very much in determining whether a migrant be a new arrival or a bird he has already observed and recorded, and as to the length of stay of visitants.

To such an extent is attachment to a limited area manifested, that visiting birds may be quite confidently looked for in the section where they have already been seen, with small chance of disappointment, if the bird still be present and not have taken its departure. In consequence of this attachment to a location, even in migration, an observer may state to another person who was absent at the time where he saw a certain bird of especial interest, and observer number two is quite certain to find the object of his desire where it was described to be, and this, it may be, hours afterward, or even on the next day.

With reference to the singing of the migrant birds within the Garden, it may be said that in the notes which follow upon the respective species it is recorded whether the male birds have been heard in song or 
not. But it may be stated that generally they are in song, and that a good suggestion, if not a full realization, of what the song of each species is may be obtained. To be sure, it must usually be heard under the disadvantages of noise, and the spirit of the singer may not be as intense as when he is on his nesting-ground; but knowledge and pleasure untold may be derived by availing of the opportunities afforded, and in calmness of mind becoming attuned to the happy life and the sweet expressions of it which are at hand.

One feature of the spring and summer bird-life within the Garden is the presence of a half-dozen European swans upon the pond. These have been introduced in recent years. In late autumn these swans are removed to winter quarters. Another feature which has manifested itself also quite recently is the permanent residence within the Garden of a considerable flock of pigeons, which have adopted a Kentucky coffee-tree standing by the fern-grown rockery as headquarters. These pigeons 
roost upon the branches of the tree and have become so tame that they alight upon the shoulders and arms of visitors who come to feed them and scarcely remove themselves out of the way of passers-by. On the Common a similar flock lives just within the grounds near the Park Street subway station and affords much pleasure and interest to visitors who bring them food and linger to enjoy their beauty and confiding tameness.

The annotated list which follows this introductory chapter includes the names of species which have been observed in the years I900-I908, and of six additional species seen by other observers in earlier years, namely, American golden-eye, American woodcock, barred owl, saw-whet owl, belted kingfisher, and winter wren (the last in the Granary Burying-Ground). No attempt has been made to gather older records, although many observations must have been made, perhaps casually, by persons who, always moving through out-ofdoors with their eyes and ears open to 
54 BIRDS OF THE PUBLIC GARDEN

nature, have been witnesses of interesting occurrences. The list contains the names of one hundred and sixteen North American birds, arranged in the order adopted by the American Ornithologists' Union and under the nomenclature most recently revised by its committee, and it concludes with the names of two introduced species and two species of the Eastern hemisphere represented by individual birds which had undoubtedly escaped from captivity. 


\section{ANNOTATED LIST \\ OF THE}

\section{BIRDS OF THE BOSTON PUBLIC GARDEN}

AND INCIDENTALLY OF THE COMMON

IN MIGRATION

1900-1908 



\section{Herring Gull}

Larus argentatus

Herring Gulls, not as migrants, but as winter residents, are occasionally seen passing over northwestward to the Charles River Basin and inland ponds, sometimes a single bird and sometimes a dozen or twenty birds. Very infrequently one or two have been seen in the early morning flying in the opposite direction. On April 25, I906, thirty were seen for a time to circle over the Garden. Usually the occasional passages over continue well into the month of May. This was especially the case in I905, when the last bird noted passed over northward in the morning of May 23.

In the autumn, year by year, Herring Gulls have also been seen, not daily, but occasionally, as in the spring. The earliest fall records are of one in flight on October I3, I905, and of one on October I4, I908. 


\section{American Golden-eye Clangula clangula americana}

In the "Ornithologist and Oölogist," I89I, vol. xvi, p. I74, is the following note: "David Hunt, Jr., reports that a Goldeneyed Duck was in the pond at the Public Garden, Boston, Mass., at 6 P. M. of Saturday, November 3ist [1891]. On approach he rose and flew toward the river. The identification was positive, as he approached within fifty yards."

The species is an abundant winter resident on the Charles River Basin.

\section{Canada Goose}

Branta canadensis

In the early morning of October 22, 1907, a flock of eight Canada Geese passed over the Garden at a comparatively low elevation in a southward direction, flying in the characteristic wedge-shaped form. They were not calling.

No other record of the species has been obtained. 


\section{Black-crowned Night Heron}

Nycticorax nycticorax nevius

Two Night Herons upon two occasions, May 20, 1903, and May 18, 1907, flew into the Garden and about the pond for a few minutes and were gone. The species, therefore, is only a casual visitor. The visits recorded were in the very early morning, and on one of the occasions the weather was cloudy.

\section{AMERICAN WOODCOCK \\ Philohela minor}

Mr. Bradford Torrey furnishes this graphic account of a Woodcock which he saw in some year previous to 1900 .

"I once saw a Woodcock flying down Beacon Street, just in front of the secondstory windows. It was on a Sunday morning. He was under full steam and turned into a place or street shortly before getting down to Charles Street. 'T was a queer sight. He was close to the houses, as I remember it, over the sidewalk, and, I should 
60 BIRDS OF THE PUBLIC GARDEN

think, must have felt as queer as he looked."

In his essay "On Boston Common" Mr. Torrey mentions once finding the body of a Woodcock which had evidently met its death against an electric wire.

No recent records have been obtained.

\section{Solitary SANDPIPER \\ Helodromas solitarius}

On May 3, I905, and again on May 23, I907, a Solitary Sandpiper has come into the Garden on the wing, lit upon the stone curbing of the pond, and after taking two or three successive flights over the water has departed, having made only a few minutes' stay. These very brief visits suggest that such birds may come into the Garden more often than they have been recorded and pass out unobserved after, it may be, only a moment's delay.

Dr. Charles W. Townsend furnishes me with an autumn record of a Solitary Sandpiper in the Garden, namely, on September 27 , 1905 . 


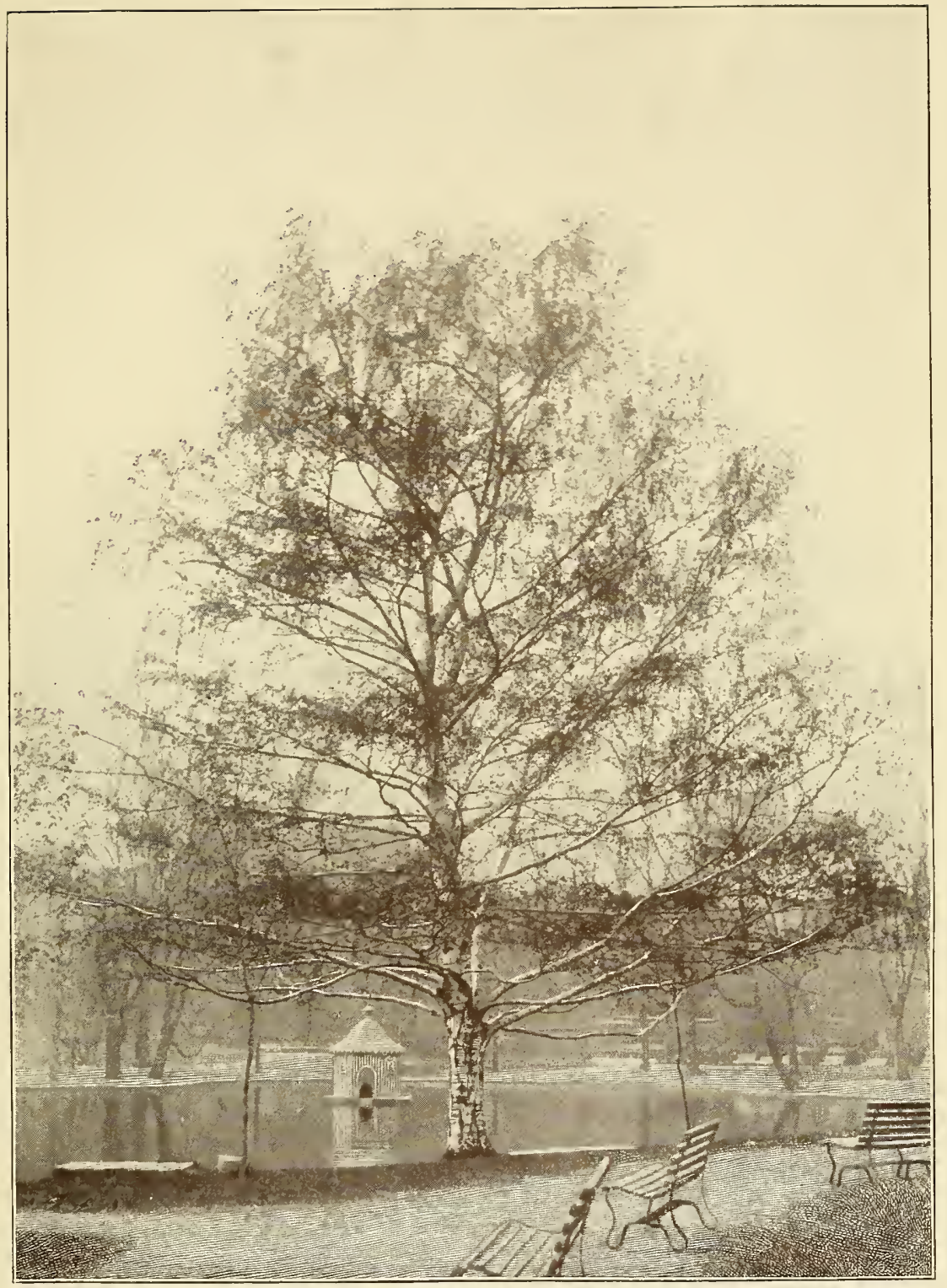

THE EUROPEAN WHITE BIRCH 



\section{Spotted Sandpiper}

Actitis macularia

In five of the nine seasons of observation the Spotted Sandpiper has been recorded; in four of these seasons a single bird only has been seen. But in 1907 there were three successive visits of the species; one of a bird on May 9, which remained a half-hour, following the curbing round the pond and taking flight to another portion only when disturbed; another of a bird on May I3; and the third visit was of two birds on May 25, which made a more prolonged stay and showed little disposition to leave.

On other occasions the departure of the visitant has followed so closely upon its entrance that there has been opportunity to view it only two or three times in its flights over the water and clearly identify it before it was gone.

The records show the period of migration of the Spotted Sandpiper through the Garden to be from May 9 to 25 . 


\section{8. Вов-WHITE \\ Colinus virginianus}

Dr. Charles W. Townsend furnishes this interesting record: "I saw a female of this species in the Public Garden near the Everett statue on June I6th, I906. The bird was wild and flew to the protection of some bushes when approached."

As the Garden is separated from the parks of the Back Bay district and beyond by at least a mile of Commonwealth Avenue, it is surprising that this bird found its way to the heart of the city.

\section{SharP-SHINnEd HawK}

\section{Accipiter velox}

A Sharp-shinned Hawk was seen flying over the Gardèn on May I3, I907.

Doubtless similar opportunities of recording a hawk of one of the more common species have occurred from time to time and have been missed, because the observer's attention has been concentrated within the Garden. 
In furtherance of this idea I may state what Mr. Francis H. Allen communicates to me. He writes that when he saw the barred owl on the Common, November 5, I888, there was a small hawk in the next tree to it, which he thought was a Sharpshinned Hawk, but that he did not identify it positively. He further states: "I have also seen a probable goshawk, one or two small falcons, and some buteos, none of which were positively identified as to species."

\section{IO. BROAD-WINGED HAwK}

\section{Buteo platypterus}

On the morning of April 24, I905, the grackles were noisily scolding in a group of trees beside the pond, and upon investigation the cause was found to be the presence of a Broad-winged Hawk, perched in an elm about fifty feet from the ground and entirely indifferent to their cries and my near presence. At length, after a satisfying scrutiny of the bird, I dislodged it by persistent hand-clapping; but it flew only a 


\section{BIRDS OF THE PUBLIC GARDEN}

short distance to another perch. The same thing was repeated, and still the bird did not fly from the Garden. The characteristic traits of this species of hawk were well brought out, therefore, by its manifestation of sluggishness and an absence of suspicious fear, also by its short flights. It prolonged its stay beyond my own.

\section{American Sparrow Hawk}

\section{Falco sparverius}

On one occasion only, in the early morning of May 9, I908, has a Sparrow Hawk been seen within the Garden. It was found perching high in the tall gingko tree which stands near the Ether Monument, and it did not take wing for perhaps ten minutes, when it flew off over the line of Commonwealth Avenue.in the direction of the Fens, where it has been found to be a usual bird during the winter season. 


\section{I2. BARRED OWL}

Strix varia

Mr. Francis H. Allen furnishes a record of a Barred Owl. The bird, he states, was seen on the Tremont Street mall of the Common, November 5, 1888 .

Mr. Bradford Torrey's interesting account of an owl on the Common in his essay "On Boston Common" records the presence of another owl on a cloudy November afternoon, probably in one of the years just preceding I883, whether a Barred Owl or not is not stated.

\section{I3. SAW-Whet OWL}

Glaux acadicus

Mr. John H. Hardy, Jr., writes me that in the fall of 1892 , probably in the month of November, he saw an Acadian, or Sawwhet, Owl in one of the elms on Beacon Street near the corner of Charles Street. Mr. Hardy says: "A crowd was watching a boy climb the tree to get the bird, and really the fellow almost succeeded, but the owl gave him a cold stare and flew away." 


\section{BIRDS OF THE PUBLIC GARDEN}

\section{I4. SCREech OWL \\ Otus asio}

About three o'clock in the afternoon of December 30, I908, Mr. Eugene E. Caduc sent me word that there was a small owl on the Common near to Joy Street, and very kindly kept the bird in view until I could reach the spot and designate its name. It proved to be a Screech Owl of the gray phase. It occupied a horizontal bough of a linden tree which stands by the footpath from Spruce Street to Winter Street. The afternoon was evenly clouded, and against the gray sky the form of the little owl with ears erect was clearly silhouetted. It did not move in the space of an hour's time, except once or twice to turn the head a little sidewise. One could see the chilly breezes blow its feathers, and it stood apparently contented and happy, giving no attention to a little group of persons who stood wondering beneath it or to passers-by who looked upon it with an interest which the rarity of the occurrence awakened. 
After I had departed Mr. Caduc and his friend Mr. Potter remained and saw it take two short flights in the direction of the Union Clubhouse and then a longer flight down towards the Frog Pond. The darkness of evening had then fallen upon the Common.

Mr. William Brewster in his "Birds of the Cambridge Region" says: "Even that densely populated part of Boston known as the Back Bay district is now occasionally invaded by these daring and adaptive little owls; Dr. Arthur P. Chadbourne tells me that he heard one wailing in the trees on Marlborough Street during the evening of January 3I, 1902, and late in December, I903, my assistant, Mr. R. A. Gilbert, saw another which had just been caught on the doorstep of a house on Commonwealth Avenue."

\section{Yellow-Billed Cuckoo}

Coccyzus americanus

The song of this species of cuckoo came several times distinctly to the ear in the 
forenoon of May I9, I907, a day which surpassed all other days but one in the series of years in respect to the number of migrant birds within the Garden inclosure. The temperature was $80^{\circ}$, following a warm night, and the migration movement had been very large. With sixteen species of warblers, numbering seventy-four recorded individuals, had come many catbirds, some late purple finches, and even a blue jay. The Cuckoo appears to have been drawn irresistibly into this mixed company. It must be regarded as a rare bird in the Garden. This is the only record which has been obtained.

\section{I6. Black-Billed Cuckoo} Coccyzus erythrophthalmus

One record, and one record only, of this species of cuckoo has been obtained by me. On May 30, I908, a Black-billed Cuckoo was seen sitting quietly on a bough of the large white willow which stands at the northwest corner of the pond. At first the bird sat crosswise of the bough, later hori- 


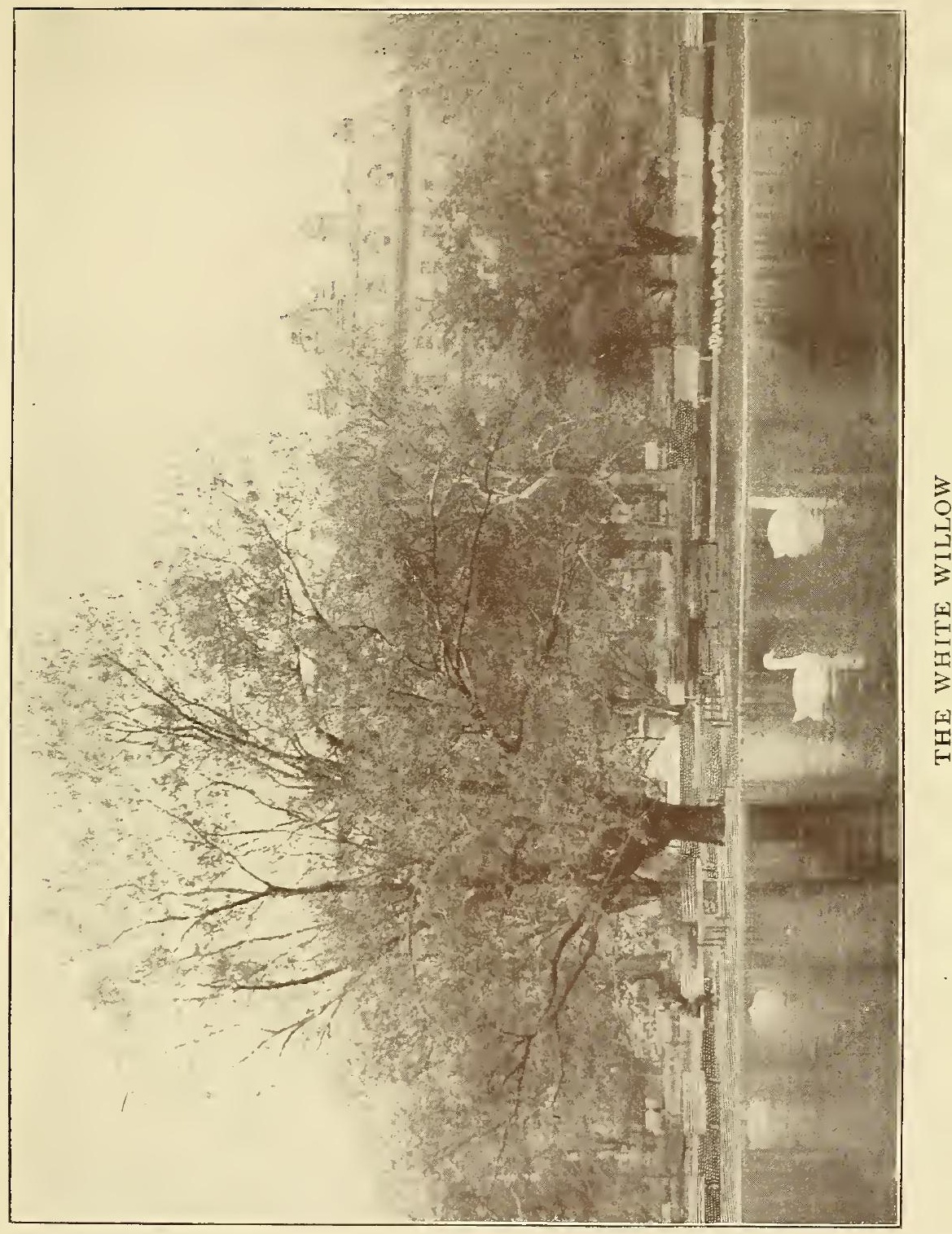



zontally along it. I saw it eat a near caterpillar, but otherwise it was inactive. It was also silent. But the close approach which I was able to make revealed it to be a black-billed bird.

Mr. E. E. Caduc informs me that he saw a Black-billed Cuckoo daily in the Garden between June 8 and I7 of the same year, that it was always seen in one of two or three maples near the northeast corner of the pond, that he searched carefully for a possible mate, thinking that a nesting of the species might be going forward, but that he found none, and that the bird was not seen after June I7, although he continued his daily visits up to July 3. The bird, he says, not infrequently gave its call.

\section{I7. Belted Kingfisher}

Ceryle alcyon

Mr. Francis H. Allen states that he saw a Kingfisher flying over the Granary Burying-Ground, and probably also visible from the Common, on September 21, I896.

Mr. Bradford Torrey records that twice 


\section{BIRDS OF THE PUBLIC GARDEN}

in the fall he found a Kingfisher about the Frog Pond. "Once the fellow sprung his watchman's rattle." These occurrences were previous to the year I883.

Dr. Charles W. Townsend writes me that he has in his collection the skin of a female Kingfisher which was found dead on Marlborough Street near Clarendon Street on October 5, I907, the bird apparently having been killed by striking the house.

\section{I8. HAIRY WOODPECKER}

\section{Dryobates villosus}

In two spring seasons a Hairy Woodpecker, a male bird each time, has made a lengthened stay in the Garden, occasionally passing over to the Common and being noted there when not seen in the Garden. The first visit was of a bird which appeared March 27, I904, and remained until April I 8 ; the second visit was of a bird which remained from March I9 to 28, I905. Both birds at times gave their long rattle calls.

Two autumn and winter records have also been obtained, one of a bird in the 
middle of November, 1903, which remained about a week, and one in late December, I904, on the Common. This was probably the bird which Mr. F. H. Allen informs me he saw on January 3, I905. In both of these instances also the birds were males.

\section{I9. Downy WoODPECKER}

Dryobates pubescens medianus

One visit of a Downy Woodpecker to the Garden covered three days, April 4 to 6, I903; another visit five days, April 3 to 7 , I906; a third visit was of a female bird on April 2I, I906. In I908, a Downy Woodpecker appeared in the Garden on March I4 and another on March 20. The rattle call was often heard in these several instances, which constitute all the spring appearances of the species.

In October the visits of the Downy have been more prolonged and somewhat more frequent, and the stay of one bird extended to November I7, in 1907 , when it was seen on the Common. The species is not a regular visitant to the Garden. 


\section{Yellow-Bellied Sapsucker}

Sphyrapicus varius

There have been four spring visits of the Sapsucker in the Garden. The arrival of the species on the first three occasions was each time on April 24 or 25; namely, two birds were noted in 1903 for a single day; two male birds were seen in 1905, one remaining to the third day; and a female bird was seen on April 25 and 26 in I906. In I908 a male bird appeared on April I7 and was not seen the next day.

In October, I908, two Sapsuckers were seen in the Garden on the eighth day, one remaining to the next day; and another, a male bird, appeared on the nineteenth and was seen again the day following.

The Sapsucker, therefore, proves to be as frequent a visitor to the Garden in the spring as the downy woodpecker, but visitants remain a shorter time. The only autumn records are those of 1908. 


\section{I. NORTHERN F́LICKER}

\section{Colaptes auratus luteus}

The Flicker, or Yellow-Hammer, is a regular visitor to the Garden, and usually several birds come each season. There have been comparatively few March records of the species. Many of the occurrences are of a single bird. Once, however, in 1906, on April I4, three birds were seen and again seen the day following. Several times a visit has been prolonged ten or twelve days, especially in the case of visitors in April. Not infrequently the strong, lusty song has been heard, and the sharp call also. In the case of a bird which remained to May 23, in 1906 , the song came one morning from the roof of the Sears residence on Arlington Street. The visitors often pass over to the Common and back again. Occasionally they drop to the ground and feed, but are generally upon the larger trees and often fly to the willows on the island.

In evidence of the nesting of Flickers on the Common, Dr. Manning K. Rand 


\section{BIRDS OF THE PUBLIC GARDEN}

writes me that in the spring of 1907 he saw two or three young birds going through a sort of dance together on a grass-plot at the left of the Joy Street path from Beacon Street. Dr. Rand says: "I do not know where they nested. They were young birds because they were not fully feathered and still had some of the down on their heads sticking through the feathers." Mr. Chester S. Day, I am informed, in the same season observed an old bird coming out of a nesthole in the same section of the Common. Mr. E. E. Caduc informs me that he saw a Flicker on the grass in the Garden on July 2, 1908, and that two Flickers were seen on the Common at intervals during the summer of that year.

Quite regularly in October and November Flickers are again present. The stay of the autumn birds is often quite extended. One was seen occasionally on the - Common in 1907 into late December. This bird was seen in the Garden on December I6 by Mr. Glover M. Allen. In I908, Mr. Caduc informs me that he saw four Flickers 
together on the Common in the vicinity of the burying-ground on December 4 to 6 . I saw one on Monument Hill in the morning of December 30 of that year, and the bird was seen by Mr. Caduc on January 4 and 5 , I909.

\section{NIGHTHAWK \\ Chordeiles virginianus}

One or two Nighthawks are heard regularly each season calling from the sky over Beacon Hill or the Back Bay. The call has sometimes been heard and the bird seen overhead in the early morning, while attention was being given to the songsters within the Garden. The middle of May is the usual time for the appearance of the species.

In 1908 a Nighthawk was heard over Beacon Hill in the evening of May 24, and the next morning between three and three forty-five o'clock was constantly calling. The following morning, May 26, one was heard up to four-thirty o'clock, and in the early afternoon of that day, two o'clock, 
76 BIRDS OF THE PUBLIC GARDEN

was in the sky over the houses, elevated not very high above them, and calling at regular intervals. This was a very warm day of $84^{\circ}$ temperature in the shade at the time, and the sun shone hot in a clear sky. The calls were given also in the quiet of the evening. Two birds were heard in the evening of May 30.

Nighthawks are known to have regularly nested on the flat graveled roofs of buildings in the Back Bay district in recent years.

\section{Chimney Swift \\ Chcetura pelagica}

By the middle of May from one or two to ten or twelve Chimney Swifts may be seen scurrying overhead in their rapid flights, appearing and disappearing and reappearing, uttering their hurried twittering notes in greeting of the day.

The earliest record is of a bird on May I, I907; in 1902 one was seen on May 6. But usually the appearance of the species dates from May I3 or I4, when com- 
monly half a dozen Swifts may be seen and heard.

In the morning of May 26, I908, thirty Swifts were counted in the air over the Garden, and on June I a half-dozen were still about.

\section{Ruby-throated Hummingbird}

Trochilus colubris

I have found the Hummingbird a very infrequent visitant to the Garden. Indeed, in two seasons only have I records of the species, namely, I905 and 1908. In the former year on May I3 and again on May I 8 a single bird was observed in flight, and on May 2 I a female bird was seen perching. In I908, on May 24, a Hummingbird visited the Garden.

Friends have two or three times mentioned seeing a Hummingbird in other years, but later in the season than my observations had extended. 


\section{KInGBIRD \\ Tyrannus tyrannus}

The Kingbird has been recorded in seven of the nine seasons. The species has usually first appeared between May I5 and I8, represented by a single bird, and commonly this bird has remained but one day, sometimes two days. Then a second migration has occurred five or six days later, on May 20 to 25 , usually a single bird appearing and for one day only. But on May 20, I907, the unusual occurrence of five Kingbirds present together, and in one tree, was recorded. None remained to the next day. The earliest appearance of the species was on May 9, 1906, one bird. Mr. Caduc informs me that he saw two Kingbirds on the Common, May 3I, I908. They did not remain. The song has been heard.

\section{PhсEbe}

Sayornis phobe

The Phœbe is an infrequent visitor to the Garden. The species has been recorded 
in the spring in four seasons only; namely, one bird on April I7, r902; three birds on April 5 and 6, I903; one bird on March 29, I905; and three successive visitants in I908, one on March 29 and 30, one on April 6, and one on April 2 I to 23. On the occasion of the three birds in the Garden, in I903, there were two others on the Common. The migration period of the Phœbe has extended, therefore, from March 29 (twice) to April 23. The birds have invariably been silent.

Twice in the autumn the species has been recorded: in the Garden one bird on October 20, rgor ; on the Common one bird on October I3, r907.

\section{Wood Pewee}

Myiochanes virens

One or two Wood Pewees have usually been recorded in the Garden each season. The earliest appearance of the species was on May 16, in 1905. The latest date of arrival was of a bird on May 26, I906. The visitant has always been in song and, ex- 
80 BIRDS OF THE PUBLIC GARDEN

cept on one occasion, has remained but one day. The exception was a Pewee in I900, which remained five days, and sang each day, from May 18 to 22, and then disappeared. In I908 two Wood Pewees visited the Garden on May 24, one in song and the other not. They were not subsequently seen or heard.

\section{Yellow-Bellied Flycatcher}

Empidonax flaviventris

In two seasons only has a Yellow-bellied Flycatcher been recorded, namely, in 1905 and I908. In the former season two birds appeared on May $\mathrm{I} 8$, and while one disappeared at once, the other, presumably the same bird, remained five days. Again, on May 27 of the same year a bird of this species was seen.

In 1908 one visited the Garden on May 24 , for that day only. In these several instances the birds were silent. 


\section{Least Flycatcher}

Empidonax minimus

Every year of observation the Least Flycatcher, or Chebec, has been present in the Garden. There have been nineteen occurrences of the species in the nine years. In I906 there was but one visitant. In 1907 there were three records. The earliest appearance of the species was on April 29, I908, one bird. The usual time of arrival is between May I2 and I5. A second wave of migration has brought others each season between May I7 and 20.

In several instances the stay of a visitant has covered nearly or quite a week. In I902 a bird was present from May I7 to 23, seven days. In 1907 one was present from May I9 to 24, six days. In 1908 two birds were singing high up in the tops of the tall trees on May 24. None in any season has remained later than the lastmentioned date. The species is usually in song. 


\section{Blue Jay}

Cyanocitta cristata

The Blue Jay on comparatively late migration dates has quite regularly made its appearance in the Garden, giving its loud " jay" cries. It has appeared in the larger migration movements, and generally in the middle of May and later rather than in April. I have records of but two April appearances, namely, in the middle of the month; while a Jay has come with the warblers, flycatchers, and later sparrows several seasons on the date May 14, and at other times between May I 8 and 26, a single bird in every instance. Mr. E. E. Caduc informs me that occasionally in the month of June, I908, the cry of a Jay came to his ear while he was in the Garden.

There have been three October records of a Jay present, in 1905, I906, and 1908.

I know of the presence of the Blue Jay in the Garden only at these migration seasons, and then only transitorily, a bird . seldom being noted a second day. 


\section{I. American Crow}

Corvus brachyrhynchos

The presence and call of the Crow at intervals in all of the three months of the spring migration have regularly been noted. Some seasons a single bird has appeared for one day only. In other seasons a Crow or a pair has been noted intermittently for a considerable period. In April, I907, two were repeatedly seen during the first half of the month, and one during the second half; but there was no May record of either.

In May, I900, as noted by Mr. William Brewster in his "Birds of the Cambridge Region," a pair of Crows nested in the rear of a house on Beacon Street, near the Somerset Club. Mr. H. A. Purdie furnishes the following account of the nesting: "The nest was built in an old, tall weeping willow which stands in the stableyard, and was placed high on one of the larger limbs. Here three young were reared. Two of them were taken from the nest and given to a person in a suburb, who kept 
84 BIRDS OF THE PUBLIC GARDEN

them as pets a while and then gave them their liberty. The third nestling fell to the ground and was cared for at the Puritan Club on Spruce Street. The nest, or a portion of it, remained in position for a long time, showing it was well constructed. The old birds were occasionally heard cawing and seen flying over the Common, Louisburg Square, and its vicinity. Presumably they obtained some of their food at low tide on the flats back of Brimmer and Charles streets." During the month of May one or the other of this pair was often seen or heard by me about the Garden. In I904, and again in I905, one and sometimes two Crows were seen quite up to the end of May, but the nesting-site was not determined.

In the autumn, also, one or sometimes two Crows have been seen, usually flying in from the westward, and sometimes passing over and at other times alighting and perching within the Garden. In the latter part of October, I905, the repetitions of a Crow's coming day by day soon after sun- 
rise indicated that they might be the excursions of the same bird, probably from the Fens or Brookline. Again, in October, I908, there were similarly repeated visits, often of two Crows which came from the same direction and continued their excursions to the Garden in this way up to November 7 , often alighting and calling.

Mr. E. E. Caduc on December 26 of that year saw one Crow silently perching in the Garden and another on the Common.

The Crow, therefore, appears as a migrant in or over the Garden, as an excursionist from the larger parks and suburban towns, and once has been present as a breeding species in the immediate neighborhood of the Common.

\section{BoBOLINK}

\section{Dolichonyx oryzivorus}

It was not until the year 1907 that a Bobolink was seen within the Garden. Then in the early morning of May I4, soon after my entrance, the joyous song of this species came to my ear, and the songster 
was seen in flight over the brilliant tulipbeds of the centre path, - seen none too soon, for he was quickly gone.

But again, on the morning of May 20, the experience was repeated, except that the singer remained to take several flights and move about upon the grass. Both visits, however, were fleeting, and both occurred upon days of migration-flights, when large numbers of migrant birds had arrived.

Mr. Bradford Torrey states in his essay "On Boston Common": "I once heard a Bobolink sing in our Garden (the only one I ever saw there)." Of this bird he writes me, "The Bobolink was not far from the Washington monument, and I remember still how surprised and delighted I was to see him."

\section{COWBIRD}

Molothrus ater

No Cowbird had been noted within the area of the Garden or the Common until the season of I908. On March 29 of that 
year Mr. Glover M. Allen writes me that he saw a Cowbird in the Garden near the pond.

In the early morning of April 7 of the same year I heard the characteristic cowbird whistle from a tree on the Common. It was the day which brought the first vesper sparrow, the first swamp sparrow, and the first hermit thrush of the season to the grounds and contributed to the number of song and fox sparrows which were present. The whistles were heard but a few times, when the bird took wing and flew away.

In the winter of I904-05 a male Cowbird roosted nightly with the house sparrows in the King's Chapel Burying-Ground, where, as all Bostonians know, the sparrows congregate in vast numbers to spend the night in the few trees standing therein, measurably protected by the walls which rise around it. Mr. F. P. Spalding in the engineering department at the City Hall discovered the bird on November I6, a date which would indicate that it was a "leftover." I saw it upon November 25 and De- 
cember 2, I904, and January Io, February I, March I and 24, and April 3, I905. The bird daily went forth with the sparrows, as they scattered in the morning to their feedinggrounds, some no doubt going quite a distance from City Hall, but it was never seen again until at the sunset hour with the reassembling of the host he again reappeared and took a perch for the night. Mr. Spalding states that its arrival among the sparrows was frequently made known by the very loud chirping of the sparrows that had previously arrived, and one was safe in saying, "The bird has come," and upon looking out of the window it would be seen among the largest bunch of sparrows. His final disappearance, which probably was on April 4, occurred at the time in the spring when migrants of his own species were arriving in the country fields and pastures, and doubtless he found companions of his own kind to join and reëntered into the joys of life with them. 


\section{Red-Winged BlackBiRd}

Agelaius phoniceus

Upon no day has more than a single Redwinged Blackbird been recorded within the Garden; but usually there have been several successive visits of a bird during each season. The earliest appearances of the species have been on March 26, 1907, and on March 30, I908. There have been but five April records. Most of the visits have been in May, and all, excepting in one instance, have been made by a male bird which has flown in, it may be, from the Fens, and, after taking a lofty perch upon one of the trees standing by the pond, has sung freely for a brief time and then retired again. I have not found a bird remaining during any considerable portion of a day or even while I completed my morning round. It may be, therefore, that these May appearances of a Red-wing are commonly morning excursions from a chosen neighboring haunt; for sometimes upon four or five mornings in succession such brief visits 


\section{BIRDS OF THE PUBLIC GARDEN}

have been paid, presumably by the same bird. The visitors in almost every instance sing and thus appeal rather to the ear than to the eye of the observer; for they do not fly through or about the Garden, but, coming through the upper air, alight in a treetop and there attract attention by their singing. They go in the same manner, rising well into the air and flying off over the house-roofs in the direction of the Fens.

I have but one record of a female Redwing in the Garden, namely, on May 2, I902.

\section{Baltimore Oriole}

Icterus galbula

The Baltimore Oriole, or Hangbird, is one of the very few summer residents of the Garden, never failing to nest upon some of the slender, hanging boughs of the elms. The earliest arrival of the species in the Garden was on May 5, I905, when two male birds were singing in the early morning. The latest arrival was in 1907, namely, on May I4. The usual time of the Oriole's 
appearance has been between May 8 and I2, in four of the nine seasons the arrival having been on May 9. The males precede the females, although sometimes they are but a single day in advance.

Two or three pairs have proved to be the quota each season for the Garden. But in I908 four nests were constructed. Other pairs nest on the Common. On one occasion, May I I, I905, seven males and three females were present together. The extra males, however, retired, as but three nests were built. Usually no more are present upon any day than have come to remain. The nest-building follows quickly after the arrival of the females.

In 1908 a fema!e Oriole started her nest upon a slender bough of an elm on the Beacon Street mall, but she was rudely frustrated in her home-making by a pair of house sparrows, which so assiduously built upon the half-made nest of the Oriole as a foundation that she could not proceed with her more delicate and painstaking weaving and was forced to select another site. 


\section{BIRDS OF THE PUBLIC GARDEN}

One of the nests of I908 was hung from the bough of a willow which stands by the boat-landing. The bough selected was in the top of the tree. Evidences do not remain in the autumn that the several pairs have built a second nest; for, when, the trees become bare of leaves, only the nests which had been observed in the process of construction in May are to be seen.

The species has disappeared in the autumn before the time when my observations have been resumed. But Mr. Maurice C. Blake furnishes the record of a female Oriole present in the Garden on September 8 , 1905 .

\section{Rusty Blackbird}

Euphagus carolinus

Usually one Rusty, and that commonly a male, appears in the Garden each season, but sometimes two successively. The visit is very transitory. I have no record of the continuance of one to the second day. The birds usually follow round the margin of the pond, either upon the curbing or 
below it upon the shore in case of low water. Occasionally in all instances the characteristic, explosive whistle of the species has been heard.

The earliest recorded bird was a male on March 23, I907; the latest a male bird on May I3, I902, and on the same day in 1908. There have been five visitants in early April. The only instance of the presence of two birds together was on April 3, I908, both males. A female bird came on May 7 , I90I, and one was on the Common April $23,1902$.

\section{Bronzed Grackle}

Quiscalus quiscula aneus

The Bronzed Grackle, or Crow Blackbird, .was about beginning its occupancy of the Garden as a summer resident, it would be surmised, when observations were begun there in 1900 ; for the presence of two pairs only is recorded that year and the year following. But Mr. Torrey in his essay, published in the "Atlantic Monthly" of February, I883, speaks of a few having taken 


\section{BIRDS OF THE PUBLIC GARDEN}

to building their nests in one corner of the domain at that time. So it would seem as if the species made no gain in numbers within the Garden for a period of twenty years. In 1902 the number had doubled that of I90I, but there were then only four pairs. In 1903 the number had more than doubled again, and the record shows ten pairs nesting. In 1904 there were fourteen nests; in I905 eighteen nests; in I906 thirtytwo nests. The year 1907 marked a diminution of pairs, as the number of nests observed was but twenty-five, and in 1908 about the same number was recorded. This diminution may have been due in part to a severe pruning of the English hawthorns, which left them no longer the thick trees coveted for nesting which they had been. The consequence was that some pairs resorted to the tops of the tallest deciduous trees for nesting-sites, and doubtless there were not favorable places enough for as many as the numbers of I906. Some of the surplus passed over to the Common, for there was an increase in the number of pairs which nested there. 


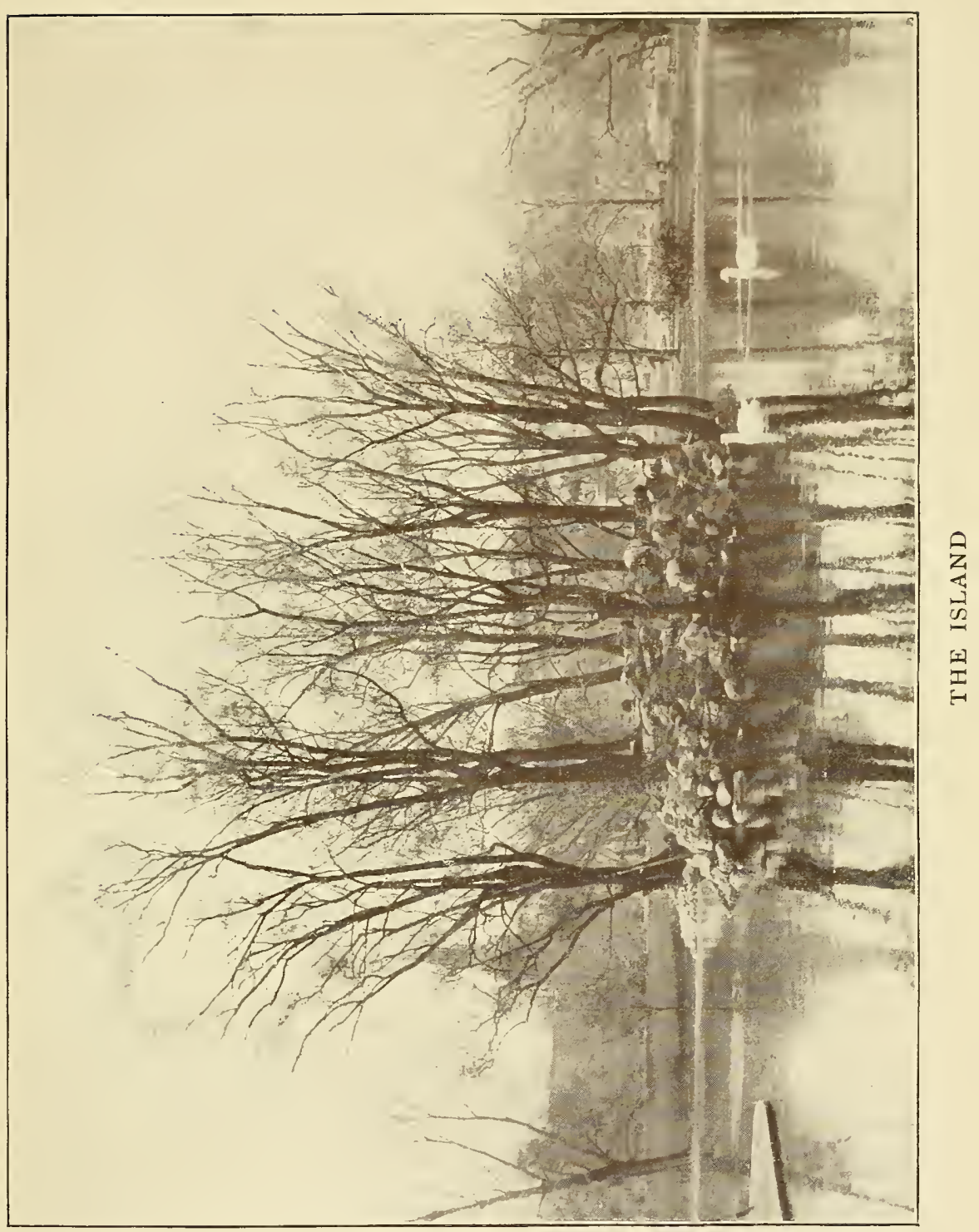



In five years, therefore, from 1902 to I906, there was a rapid increase of grackles breeding within the Garden, and such a check as occurred in 1907 was doubtless desirable.

The earliest arrival of the species was on March I I, I906, when two birds appeared; but this earliness of date was offset by their disappearance after six days, owing to a week of wintry weather, in which the mercury dropped to $\mathrm{II}^{\circ}$ and two snowfalls occurred, depositing fifteen inches of snow. There was a reappearance of these two birds, or other two, on March 25, followed by successive additions until the number of nesting birds reached sixty-four. The next earliest arrival was in 1908 , when three birds appeared on March I2. The latest date of arrival of the species within the Garden was March 24, in I904. The usual time of coming has been between March I6 and $I 8 .{ }^{1}$

1 A male Bronzed Grackle, which had returned to the Garden for the season of I 909, was seen by me on February 26 in a purple beech which retained on one of its 


\section{BIRDS OF THE PUBLIC GARDEN}

By the first of May many nests have been begun or already contain eggs, and by the end of the month the young grackles have left the earliest-built nests. These birds of beautiful iridescent plumage add much to the charm and happy life of the Garden, and their notes, though unmusical, fall not unpleasantly on the ear of bird-loving visitors. Their value, also, in destroying insect life must be beyond easy calculation.

Among all the grackles which year by year live in the Garden I have been unable to identify any individual as a Purple Grackle, and yet the opportunities have been ample on account of the tameness of the birds, which affords an observer the full-

boughs the remains of a grackle's nest of the previous year. It is interesting to record that Mrs. Charles W. Townsend, who kindly permits me to chronicle her observation, saw this grackle on February 23. A few bluebirds had appeared here and there in the vicinity of Boston on this date, and a single red-winged blackbird had also been seen by me on Arlington Heights upon that day. This first grackle, having come so early, remained alone for nineteen days. A second came on March I4, and two days later two others arrived. 
est chances to scan them and assure himself of their coloration.

Some grackles are present when observations have been resumed in October, but so few, and intermittently, that it is quite likely that they are birds which did not nest and were not reared within the Garden, but migrant birds on their way southward. In October, I908, when observation was resumed on the eighth day, no grackle was present, and none was noted until the fifteenth day. This seems confirmatory of the assumption that the summer residents had all gone and that the few records of the species made after the middle of the month were of migrant birds. Only once has a considerable flock been seen in the autumn, namely, twenty-five birds on October 24, I906; one grackle only had been present on the previous day. Dr. Charles W. Townsend furnishes an additional record of a flock in the autumn, that of six Bronzed Grackles present and singing on October I5, I905. The departure of the last birds has occurred definitely between October 
22 and 24 , except in 1906, when the date was October 26.

\section{Pine Grosbeak}

Pinicola enucleator leucura

On March 23, I907, a female or young male Pine Grosbeak visited the Garden for a few minutes in the early morning. It was seen perching on a temporary windbreak of small spruces which the gardener had placed for the winter season around a group of rhododendrons. The whistles of the bird first attracted my attention. The species had been common in the suburbs of Boston throughout the winter. This was the last Pine Grosbeak which was seen by me that season. Doubtless it was a migrant north from some more southern point, accompanying an incoming of grackles and robins.

One other brief visit of a Pine Grosbeak was on November I, I903, which time marked the beginning of a previous visitation of this species to the environs of Boston.

Mr. Francis H. Allen has furnished to 
Mr. William Brewster's "Birds of the Cambridge Region" an additional record, which is especially interesting on account of its late date, namely, that of a Pine Grosbeak in the Granary Burying-Ground on April 24, I896. The closeness of this area to the Common suggests the appropriateness of including this visitant among those of the Garden and the Common.

\section{Purple Finch \\ .Carpodacus purpureus}

There are usually several appearances of the Purple Finch within the Garden each season, but at no time has a flock been observed. Nearly all of the records are of a single bird; and sometimes the species has not appeared until May 7 or later. The earliest record is that of a bird in song on April 3, 1906. In four of the seasons one has been present as late as between May I9 and 23. These later birds have been singing freely, but they have moved on without delay to more congenial nesting-haunts.

The Purple Finch has also been an au- 
IO० BIRDS OF THE PUBLIC GARDEN

tumn visitant in October in six of the years, and in 1904 one was recorded on November 5. Although the species is to some extent a winter resident about Boston, no earlier spring or later fall records have been obtained.

\section{White-Winged Crossbill}

\section{Loxia leucoptera}

At the time of the coming from the north of this erratic species in the autumn of 1908 a single bird was heard as it passed over the Garden calling in the morning of October 21. And on November 5 two birds similarly passed over. In each instance they were flying westward toward the suburbs possessing cone-bearing trees. The trees this season were heavily laden with cones, upon the seeds of which both species of Crossbills feed.

\section{I. REDPOLL \\ Acanthis linaria}

Three times the Redpoll has entered the Public Garden record. Mr. Glover M. 
Allen furnishes the earliest record of the three, having noted a Redpoll within the grounds on February I2, I907. On the second occasion a lone bird was seen passing over northward on April 2I, 1907, at the end of a season in which the species had been abundant in the suburbs in winter flocks. On the third occasion three birds were flying over westward in the morning of November 22, I908. In both the later instances the birds gave their characteristic calls.

\section{AMERICAN GoldFinch}

Astragalinus tristis

The Goldfinch, or Thistle-bird, never has failed to make several appearances in the Garden each spring and again in October and November. The earliest appearances of the species were on April I0, I908, when seven birds were present, some singing, and on April I I, I902, when a single bird singing was noted. There have been but three other April records, namely, April 22 and 23, in I902 and I903 respectively, and April 30, 
I908, in each instance a single bird. In May the visits have occurred between May 7 and 30.

A little flock numbering from six to eight birds has been seen but four times. The occurrences of a single bird far outnumber those of two or more birds. Not uncommonly the lone Goldfinch has been in song.

Fewer individuals have been recorded in the autumn, but the species regularly reappears then and has furnished many November as well as October records, the latest birds being a little flock of four present on November 22, I903.

\section{Pine Siskin Spinus pinus}

In 1907 and 1908 only has the Pine Siskin, or Pine Finch, been recorded in the spring in the Garden. On May 20 of the former year a single bird was heard calling in flight, and on May 25 one was seen perching and singing. In I908 a Siskin appeared on May I2, when a very large general migration-flight manifested itself in the Garden. 
In four of the years of my observation Siskins have been recorded in October. In I90I two little flocks of three and five birds respectively paid a fleeting visit on October 26 and 27. In 1906 a single bird was recorded on October I7 and 22. In I907 a flock of ten birds lit in a tree-top on October I9, and again on October $2 \mathrm{I}$ a flock of six birds was noted. On October 25 one bird made its presence known by giving its characteristic call. And in 1908 the migration movements of the species were manifest up to November I2, two birds appearing on October Io, twenty on October I4, a flock which numbered quite a hundred passing over on October I8, and scattered birds thereafter, one occasionally coming into a tree, feeding and calling.

\section{Vesper Sparrow}

\section{Poccetes gramineus}

The Vesper Sparrow, or Grass Finch, has visited the Garden only four times during the period of my records, in three of the instances a single bird. The dates are 
April 23, I903; April 19, I904; and April I0, I905. The fourth occasion was the presence of two birds on April 26, I907.

On April 22, I907, four birds were seen on the Common on the west slope of Monument Hill. This slope has proved to be a favorite feeding-place of all of the more common species of sparrows, and I surmise that a scanning of this ground in the earlier years of my observation, 1900-1905, would have revealed more instances of the presence of this species there. It is rather to be sought there or on the level of the parade ground below the hill, than in the Garden. The other records of the Common are a bird in song on April 8, I906, and a bird on April 7, 23, and 26 successively in 1908.

I have no record showing that a bird of this species has remained over the next day.

45. Savanna Sparrow

Passerculus sandwichensis savanna

The Savanna Sparrow is a frequent visitor to the Garden and the Common 
throughout the period of its spring migration. It has been seen more often and more numerously on the Common than in the Garden; yet there are many records of its presence in the Garden. It is almost always found feeding upon the grass land; but occasionally has been heard singing from a tree. It usually appears in the second half of April, and the migration continues intermittently sometimes up to the middle of May. The earliest arrival was of three birds on March 3I, in I908. No other arrival-date has been earlier than April I I, in I904.

Seven Savanna Sparrows were observed in the Garden on April I7 and I8, I904, four of the same, presumably, remaining to April 24, thus completing an eight days' stay. The little flock was seen each morning. Nine birds were seen feeding together on the slope of the hill on the Common upon April 22, I907, and five days later seven were present. Unlike the Vesper Sparrow, the birds of this species appear, therefore, to linger several days. 
I06 BIRDS OF THE PUBLIC GARDEN

The late records of the species in the spring are of a bird on May I3 and I4, I904, none having been observed in the intervening time from April 24; of one on May I2, I905, none having been seen since May 4; of two birds on May Io, I907, while seven were seen on the Common the same day, three of them singing; of two on May I3 and one on May I4 of this same year; and of one bird on May Io, I908. The dates indicate how late some individuals of a species arrive, most of the individuals of which have come and passed on much earlier.

The records of 1904 show the migration of this species through the Garden to have covered thirty-four days, namely, from April I I to May I4; those of I908 show that the period covered was forty-one days, namely, from March 3I to May Io.

The only autumn records of the Savanna Sparrow are of a bird in the Garden on October 28, and another on October 3I, in I908. 
46. White-crowned Sparrow Zonotrichia leucophrys

The White-crowned Sparrow has appeared in five of the nine years: on May I I, I900; on May 8, I902; on May I2 to 2I, I905; on May 20 to 23, I907; and on May I 2 to $\mathrm{I} 8, \mathrm{I} 908$. In $\mathrm{I} 900$ and $\mathrm{I} 902$ one bird only came each year. Three were recorded on May 12, I905, and two of these, which were frequently heard in song, remained to May 2I, - unless it be that there was a succession of birds of this species passing through, but as just two were recorded each day of this period, it seems likely that the same two birds remained ten days, while the third bird of May 12 passed on. The year I905 was exceptional, therefore, in comparison with the foregoing years, in the continued presence of this species and in its being in song.

But in 1908, and again upon the same date, May 12, as many as nine birds were seen in the Garden and five others were observed on the Common. Several were 
singing. It is likely that more were present than were seen and counted. The numbers recorded mark the visitation of Whitecrowned Sparrows on that day as most unusual. It is possible that conditions tended to concentrate them within this city park area, for a walk with careful observation through Wellesley Hills and Farms the same day with a companion whose eyes and ears were searching everywhere like my own revealed not an individual. Several of these birds of the I2th remained, while most of them at once-passed on. The remnant gradually diminished until on the $I 7$ th and I8th there was present one bird only. The singing of the first day was continued and in generous measure upon the following days.

Three autumn records of the Whitecrowned Sparrow have been obtained, all being of a single bird in the plumage of the female or immature male, namely, on November I, I904; on October 28, I908; and on November 2, 1908.

An incident which came under observa- 
tion relating to the last-mentioned bird was this. The White-crown was upon the ground under a dogwood tree and in moving about had found a small chunk of bread, at which it was picking, when a House Sparrow, spying it, darted in from a distance. The White-crown stood erect, and with dignity received the sparrow with a spirited rendering of its song, like a cock crowing in defiance of his adversary. But the House Sparrow, with more heed to his appetite than care for the defiance, and with a cunning and quickness of motion of which the dignified White-crown would be quite incapable, seized the piece of bread and was gone. The White-crown for an instant seemed nonplussed at the loss of its meal, but calmly proceeded in its search for food, doubtless feeling that the little rascal was indecently greedy and a contemptibly sly fellow. Why should it not feel so? 


\section{White-throated Sparrow}

\section{Zonotrichia albicollis}

The White-throated Sparrow, or Peabody-bird, appears in the Garden in late April. Its arrival has ranged between April $2 \mathrm{I}$ and 30 . The season of its migration has extended to May I6 to 26, usually near to the last-named date. In I905 the migration covered the full period between the earliest and the latest dates, namely, thirty-six days; in 1903 and 1904 , thirty days; in I906, twenty-seven days; in 1907, twentynine days; and in 1908, twenty-five days. The largest number of birds recorded upon any one day was about fifty on May 3, I905, and again on May I2, I908. On the lastnamed date there were almost as many more on the Common. Usually the largest number of birds present at any one time has been from eight to fifteen, and it has been attained either in late April or between May 7 and I4. The maximum number for 1907 was as late as May I9 and 20.

Many of the White-throats linger a num- 
ber of days. But, as a new migration movement generally overlaps a remnant from a previous movement, it is not easy to determine definitely the length of stay of individuals. An interval sometimes occurs after the first birds arriving in April have passed on before the more continuous movement of coming and passing takes place, but after this has set in in early May there have been few days when Whitethroats have been entirely absent. The season of 1903 was an exception, for there were only four appearances of the species, each time for a single day only, and but eight birds in all were recorded, and yet the time of migration covered was thirty days. The movements of the seasons of I905, I906, I907, and I908 were notably larger than those in the previous five years. The White-throats often sing in the early morning their peculiarly peaceful song.

In October the southward migration is always manifested in the Garden. It continued in the years 1904, I906, and 1907 to November 4 and 5. In 1903 the autumn 
II 2 BIRDS OF THE PUBLIC GARDEN

records extended intermittently to November $9, \mathrm{I}_{5}$, and 29 ; in I908, to November I2. Upon some days in the latter half of October from half a dozen to a dozen birds are usually present, few full-plumaged males at this time, but occasionally a handsome fellow. Mr. Maurice C. Blake furnishes two early autumn records, namely, one of four birds present in the Garden on September 24, and the other of two birds on October 5, in I904. The White-throats scratch among the fallen leaves under the trees, about the roots of the shrubs, and in the flower-beds among the plants.

White-throated Sparrows, unless disturbed, are usually seeking food upon the ground, and are often under the protection of the beeches with low-hanging boughs. Sometimes they are scattered about upon the lawns. They are quite likely to be in little groups. When frightened by a too near approach, they fly up among the branches of a near tree, where they may be traced by their sibilant calls. Here they await a safe opportunity to drop to the 
ground again. From the trees the song when given also comes. Some days in the spring there is much singing.

Very few White-throats as a rule choose the Common in preference to the Garden.

Invariably they are masters of the house sparrows, driving the latter off when they intrude.

The last birds seen in the spring are usually females.

\section{Tree Sparrow}

Spizella monticola

Three times only in the spring has the Tree Sparrow visited the Garden, and on each occasion a single bird for one day only. The dates are March 29, I905, March 25, I907, and March 27, I908. On the first occasion two other birds of the species were seen on the Common. The bird of I908 enjoyed a bath in the waters of the pond as they touch the shore of the small island. At the time the water was low on account of being drawn off, and it sufficiently receded from the shore to offer advantages. 
II4 BIRDS OF THE PUBLIC GARDEN

The species has never been seen by me in the Garden as a winter visitant. But Dr. Charles W. Townsend, in his "Birds of Essex County," states, - and he has kindly given me permission to quote him, - "On January I5, I904, I was attracted by the chirping of this bird [Tree Sparrow] at II.3O P. M. on the Public Garden, in Boston, and saw one hopping about on the snow near an electric light. It was soon joined by another, and both flew away chirping."

\section{Chipping Sparrow Spizella passerina}

Only one year has the Chipping Sparrow been absent from the spring record of the Garden, namely, in 1904. In 1906, 1907, and 1908 the species was more often noted than in the previous six years. The earliest appearance of a Chippy was on March 29, I905, when one singing attracted especial notice, as he was twelve to fourteen days ahead of the usual time of arrival in this section. The next earliest appearance of 
the species in the Garden was on April I4, I906. In 1907 and 1908 the day of arrival was April I8. The migration period is extended, for in 1908 it reached to May $2 \mathrm{I}$, when a bird in song was in the Garden and another was singing on the Common; twice it has reached to May 22, namely, in $\mathbf{I} 902$ and in I906, on both occasions a bird in song being noted; and in 1907 a bird was present and singing on May 28, not having then reached its nesting-haunt. In I905 the migration covered thirty-three days; in I906, thirty-nine days; in 1907, forty-one days; and in 1908, thirty-four days.

Two birds, presumably a pair, as one was much heard in song while the other was not, remained four days in I906, namely, from April I9 to 22, suggesting a possible nesting, but they then disappeared. Commonly one bird only has been noted in a day, but there is one record of a small company, namely, four birds, on April 27, I902. Usually the Chipping Sparrow remains but one day, as intervals of several days have occurred between records of its presence. 
It was found in 1907 that the species had a preference for the Common, since ten Chippies were seen together on the slope of the hill on May I ; six on May 9 and Io; and seven on May I3 after only one had been noted on May 12. In 1908 most of the visitants were on the Common, five being present on May Io. On the Common, also, there has been a somewhat stronger disposition to remain for several days.

There are records in four of the years of the species in the Garden in October, I90I, I902, I907, and I908, the visits ranging between October I9 and 30, a single bird in most instances. Two Chippies were seen on the Common on October 30, I907, and five on October 2I, 1908.

\section{Field Sparrow \\ Spizella pusilla}

The Field Sparrow, as was the case with the Chipping Sparrow, was absent from the Garden in 1904, but has been recorded as present in all of the other years. In three of the seasons one bird only was noted, 
namely, in I901, I903, and 1906. In 1902, 1905, I907, and 1908 there were several successive visits of a single bird at intervals of a few days. The earliest appearance was of a bird in song on the Common, March 3I, I902; the next earliest time of arrival was on April 9, r903, in the Garden. The latest records have been of a bird on May 16, I905; of one on May I3, I906; and of two on May I3 and I4, I907. The period of migration covered thirty-two days in 1902 and I905. Several of the visitants have sung.

The Field Sparrow also was found in 1907 to have a preference for the Common. The first two records of the season were there obtained, namely, on April 21 and 26, on the latter date there being three birds present which remained to the following day. In 1902 one bird continued there in song during four days, March 3I to April 3, singing each morning in the vicinity of the burying-ground.

No autumn records of the species have been obtained. 
II8 BIRDS OF THE PUBLIC GARDEN

\section{I. Slate-Colored Junco}

\section{Junco hyemalis}

As surely as the spring comes, the Junco, or Snowbird, makes its appearance in the Garden, generally being present in small flocks, but not seldom one bird alone. March I3, I902, has been the earliest date of arrival, when four birds were seen. The first one came on March I5 in I908; on March I7 in 1907; and on March 19 in I903. The time of arrival has been as late as March 29, when in I906 a single bird was recorded. The latest records for the species have been May 5, 1905, when one bird was present; May 3, I908, a female bird; and May 5, I908, when one was on the Common. In the other years the migration has ceased upon a date between April 22 and 27, except in 1906, when no Junco appeared after April I4.

In 1907 there was a very notable migration of Juncos into the Garden on April IO, when the number was estimated to have been fifty or more. They came in company 
with fox sparrows. A previous movement had brought on April 2 nearly as many, but most of these alighted on the Common. Also on March 29, I905, a flock of quite forty alighted on the Common, almost to the exclusion of the Garden.

The period of migration covered fortytwo days in 1902, thirty-seven days in I903, forty days in 1905, forty-two days in 1907, and fifty-two days in 1908. The silvery, trilling song has sometimes been heard, but usually only the several calls which belong to the species.

On the southward migration in the autumn the Junco is quite as much in evidence in the Garden as in the spring. The species never fails to appear successively in small flocks, at times, however, numbering twenty birds, through the month of October and sometimes to the middle of November, one bird being seen on the Common in 1907 on November I7, and one in the Garden in I908 on November I9. When a single bird is present, it is not infrequently shyly up in a tree-top, and makes its presence known 


\section{I20 BIRDS OF THE PUBLIC GARDEN}

by a twittering which is characteristic of the species. Especially does it give this when it passes from one tree to another.

Mr. Maurice C. Blake furnishes two early autumn records, namely, one of three birds present in the Garden on September 24 , and the other of one bird on October 5 , in 1904 .

\section{SONG Sparrow}

\section{Melospiza melodia}

The Song Sparrow, or Ground Sparrow, always comes in good numbers at the opening of spring. Usually a little flock is present, but there are many occurrences of one or two birds only in a day; and intervals occur between successive migration movements when none are present. The species is one of the earliest to arrive, some birds coming each year at the same time that the earliest grackles and robins come. The ice is scarcely gone from the pond, and patches of snow still linger, when the cheery song is first heard upon a mild morning in early or middle March, which has been 
ushered in by southerly breezes on the preceding day. And unlike the grackles and the robins, which come in small numbers at first, a single bird or two, the Song Sparrows arrive in goodly numbers when first they appear. So the places which have been birdless become occupied with happy songsters all in a night, and the evidences of their presence in the morning come to the ear in song on every side. The Public Garden receives a touch of such awakening from every winter's sleep. Most of these earliest visitants move quickly on, but they are followed by others in succession, in larger or smaller numbers, for several weeks.

The earliest arrival of the Song Sparrow in the Garden was on March 6, I903. In I908 they came on March 12, ten of them to the Garden and five to the Common; in I902, on March I3, twenty or more arrived; on March 19, I905, forty came. The latest date of arrival was March 28, in I906. Song Sparrows usually continue to arrive up to about the end of April; although after the middle of this month the num- 


\section{I22 BIRDS OF THE PUBLIC GARDEN}

bers present are diminishing gradually to one or two birds only. Some stragglers come along in May, having their nestingplaces still beyond them; for the species does not nest in the Garden Thus, in I904, one was recorded on May 20; in I905, one was present from April 26 to May 2, and another appeared on May 12; in 1907, one was present on May 9, three on May ıo, and two on May I3. These late migrants extended the season of migration in 1904 to a period of fifty-eight days; in 1905 the migration covered fifty-six days; in 1907, fifty-eight days; in 1908, forty-five days; and in 1902 and 1903 , also forty-five days. In 1906 the migration was small and of short duration, lasting only twenty days.

Song Sparrows show a preference for the Garden over the Common, although the latter usually receives some of the visitants in the successive movements of migration.

Regularly in October a few Song Sparrows are seen in the Garden, and four of the years furnish November records. Two were present on November 8, I903; one on 
November I5, I905; one from November I to 4 in 1907 ; and one on November 5 and 6, also 13 and 16 , in 1908.

\section{LinCOLn's Sparrow Melospiza lincolnii}

In no season has Lincoln's Sparrow failed to appear in the Garden, either one bird or two or three individuals successively. On one occasion only were two birds present on the same day, namely, May 22, I903. There have been two seasons when but one bird was recorded, namely, I90I and I907. The earliest appearance of the species was a bird on May 9, I900. In four of the years the first bird has arrived on May I2 or I3. Usually two birds have appeared successively in a season. Commonly the first has come between May I 2 and I 8 ; the second from three or four days to.a week after the first. The records show that one bird remained four days in I907; one remained seven days in 1905 ; and one remained eight days in I900. These lingerings have been within the period of 
May 15 to 23. The disappearance of the species is commonly between May 20 and 23. The presence of a Lincoln's Sparrow later than this occurred only in the years I905 and I906, when a late migrant appeared on May 27 and 26 respectively.

On but one occasion has a bird sung, when a sweet, rippling song bearing some resemblance to the music of the purple finch was heard. Not even has the call-note of this sparrow been often heard, the birds generally remaining silent. Sometimes the shyness which belongs to this species has been quite lacking in an individual, and it has been easy to make a near approach and become familiar with this trig, spirited little sparrow, whose finer streakings and buff-tinged breast well differentiate it from the song sparrow.

\section{Swamp Sparrow Melospiza georgiana}

The Swamp Sparrow in I905, I907, and I908 made such successive appearances during the season that the species might be 
regarded as not uncommon in the Garden. But these seasons have been offset by others, namely, I900, I90I, I903, and I906, when only one or two records were obtained. Seldom does the Swamp Sparrow remain over to a second day. There is no damp ground, and there are no swampy conditions within the area of the Garden. So it is natural for the individuals which drop in to seek quickly other more congenial places. The most marked exception to this statement was made by a bird in I900, which remained six days, May I9 to 24 .

The time of arrival of the species is very various. It, has appeared in March, on March 27, I905; it has sometimes first been seen in April, early or late; but most of its appearances have been in May, extending in several seasons to May 22. In 1905 the period of migration covered fifty-seven days. It is more likely to be seen in the Garden in its later than in its earlier migrations to this section. On a few occasions two, three, or four birds have been present 
on the same day, but commonly one bird only has been recorded. On April 23, 1908, six Swamp Sparrows were seen in the Garden. There is but one record for the Common, that of a single bird on April 23, 1902.

Only once has a Swamp Sparrow been heard singing, namely on April 5, 1903.

There are two autumn records, one of a bird on October 16, I904, and one of a bird on October 21, I907.

\section{Fox Sparrow \\ Passerella iliaca}

The Fox Sparrow is a common visitant to the Garden, arriving with the earliest migrants. In 1903 the first bird appeared on March 13; in 1908 two birds were seen on the Common on March 14. According to the season the forerunners of the larger flights of the species have arrived between March 13 and 30. The last bird in two of the seasons, I904 and I907, has not passed until April 22, and in 1908 one was present on April 23. There have been many records of a single bird, or two birds only, present 
in a day. And many times small flocks of four to ten birds have been enumerated.

In 1907 there was a most remarkable incoming of Fox Sparrows to the Garden upon two several occasions, April 2 and Io. At this time the water of the pond had been drawn off, leaving a somewhat muddy bottom covered with litter which had collected, and which later would be scraped together and removed. Upon this drainedoff surface in the early morning of April 2 there was seen to be a host of birds feeding, and a vigorous scratching movement everywhere about indicated that Fox Sparrows were industriously at work securing their food. A careful reckoning showed that quite a hundred were present. There were also some juncos and song sparrows with them. On April Io it was estimated that there were no less than two hundred Fox Sparrows present, nearly all of them within the limits of the stone curbing circumscribing the pond. Many juncos and a few song sparrows on this occasion also were scattered about with them. On both of 


\section{I28 BIRDS OF THE PUBLIC GARDEN}

these occasions snow had fallen the previous day, leaving some deposit of slush on the ground, but less had remained on the bottom of the pond, and it was less chilled with frost. Consequently in the generally unfavorable conditions of weather for the sparrows to obtain their food they had chosen an area presenting fewer difficulties and doubtless holding many seeds which had been blown in by the winds. On the day after each of these large visitations only about ten Fox Sparrows remained. Some individuals often remain several days. A flock of two hundred and fifty robins, as they were estimated, on the second occasion was round about in many bunches, cackling and singing. The minimum temperature of the morning in both instances was $30^{\circ}$. The sky remained clouded each time from the storm of the previous day. Therefore these great flights of the earlier migrant species took place under cold and stormy conditions, when it is not expected that such migration movements will occur. The extensive migration of the 
Fox Sparrows was observable also in the suburban places which were visited.

This handsome sparrow is shy, and when only two or three are present they may escape observation, since they are quite prone when frightened to fly up from the ground into the trees and there give only their soft, sibilant calls which may not arrest the attention.

While commonly Fox Sparrows are not in song in the Garden, I have many times heard one sing in rich, full tones the beautiful song of the species. When a bird has entered upon singing, it has often seemed as if he were constrained to sing, for he has given himself entirely over to it for a considerable time, if undisturbed. Such a songster one morning occupied the top of the old wistaria-covered arbor, which has since been removed. Another on another occasion was hidden among the spruce trees which had been introduced as a windbreak to rhododendrons.

The period covered by the migration of this species in the spring is not as ex- 


\section{I30 BIRDS OF THE PUBLIC GARDEN}

tended usually as in the case of those sparrows which are also summer residents of Massachusetts. But in 1907 it reached thirty-six days, from March I8 to April 22, and in 1908 it reached forty-one days, from March I4 to April 23. The species is little seen on the Common in the spring.

The Fox Sparrow quite regularly makes some visits to the Garden in the southward flight in October and November, and at this season not infrequently has been found on the Common also. When a dozen were present in the Garden and on the Common in the morning of November II, I908, one was seen on my way thither in a tall elm of Louisburg Square. The first autumn bird has twice appeared on October I7, namely, in 1906 and in I908. In I907 the first appearance was on October 20, a single bird. In the years 1903 and I905 it was upon October 27 and 26 respectively. The migration has extended to the middle of November for a single bird several times. One was in the Garden on November I5, in I905; one on November I2, in 1906; one on 
November 13, in 1907, and a bird on the Common on November I7; and one on November I8, I908. In the last-named year one was present on December 3 which had not been seen earlier. In both spring and autumn frequently a small flock has remained several days.

\section{TOwHEE}

\section{Pipilo erythrophthalmus}

Regularly every season there have been visits of Towhees, or Chewinks, to the Garden, from three to a dozen birds successively each year, either singly or in small companies. The earliest visitant, a female, came on April 25, I905. A Towhee also appeared in late April in 1902, a female, and in 1906, a male. Usually the arrival is in the earliest days of May, having been on May I and 2 in 1907 and I908, respectively, in both cases a male bird. The latest lingering birds have remained to May 22, in 1902 and I903, in each instance a female bird. In four other years May I9 (twice), 20, and 2I have terminated the migration; 


\section{I32 BIRDS OF THE PUBLIC GARDEN}

in all of these instances the birds were females, two in number twice.

The records show that nearly twice as many female Towhees as males have visited the Garden during the nine years of observation. But in 1907 six of each sex came. Some of these remained several days. The period of migration covered twenty-five days in 1902 and in 1905. No Towhee has been seen on the Common. The song has seldom been heard, but in 1907 on three occasions it was given. The Towhees are usually seen about the groups of shrubs, preferring to be on the ground, unless disturbed. The brown and chestnut costume of the female bird is especially harmonious and pleasing.

\section{Rose-breasted Grosbeak}

\section{Zamelodia ludoviciana}

In one year only, 1904, has the Rosebreasted Grosbeak failed to appear. In six of the years one bird only has been noted. In 1907 two male birds were present on May 9, not remaining to a second day, and 
one was present in song on May 20. On four occasions the visitant has been singing. The earliest appearance of the species was on May 9, in 1907; the next earliest on May I0, I900, and on May I2, I908. The later arrivals were on May I9 in 1903 and I906. The latest remaining bird was one which stayed from May I5 to 22, in 1905.

On one occasion in the morning a beautiful male bird sat singing on an elm bough which extended well out over Beacon Street, pouring out his song in the stillness of an early hour while the residents still slept.

The visiting Grosbeak has been usually a male bird.

\section{Scarlet Tanager}

\section{Piranga erythromelas}

In every season, except I903, the Scarlet Tanager has been seen in the Garden. On May 23, I900, there was an exceptional display of scarlet plumage, when four male birds during the hours of that day flew back and forth among the branches of the 


\section{I34 BIRDS OF THE PUBLIC GARDEN}

trees which stand around the pond and on the island. One female bird was also present at the time. Only one of the males was seen the following day. There had already been a visit from two male birds and one female on May I8. On one other occasion, May 19, I906, two male birds were present together. In other cases one bird alone has been present.

On May 23, I904, a Tanager in song proved to be in orange plumage of oriole color, and might in respect of coloring easily have been mistaken for a Baltimore oriole. The song, however, had already identified him. It was an interesting instance of the variation in plumage from the normal color of the males of this species, which one may occasionally note.

The earliest appearance of the Tanager was on May I6, I905; the latest records of one being present have been of a male bird in song on May 26, I906, and on May 27, I908. Therefore the period of migration through the Garden during the nine years of observation has been within a period of 
ten days, namely, May I6 to 27. Usually the visitant has not remained over to a second day. But in 1905 the records indicate that a female bird may have remained from May 16 to 24, nine days, as one was continuously present during that period. The male birds usually sing.

\section{Cliff Swallow \\ Petrochelidon lunifrons}

The Cliff, or Eave, Swallow seldom comes within the Garden. Twice the species has been recorded. Four birds with a flock of barn swallows were seen on May I6, I905; and two birds were present likewise with barn swallows on May 30, I907.

The visits of the swallows usually occur upon clouded and misty days. On such days they may be seen skimming over the pond in rapid flight. Thick weather seems to attract them thither, while often in clear weather no movement of a swallow within the Garden will be seen. 


\section{BARN Swallow}

Hirundo erythrogaster

In three of the seasons the Barn Swallow has not been observed, namely, I90 I, I903, and 1906. But in 1905 and again in 1907 during several days in succession in May a single bird or two, or a flock numbering sometimes a dozen or fifteen birds, was seen. On May I6, I905, as many as fifteen Barn Swallows were skimming the air in ceaseless flight; and on May 29, I907, about a dozen birds were seen, and the following day also nearly as many.

No visit of the species has been noted earlier than May 9, in I900, and most of the visits have been in the latter half of May. In 1908 one bird was recorded on June 2.

\section{I. Tree Swallow}

\section{Iridoprocne bicolor}

There are but four records of the presence of the Tree Swallow or White-bellied Swallow in the Garden. These appearances have not occurred in the earlier period of migra- 
tion of the species, for they have all been in the second half of May, between May I 8 and 30. On one occasion two birds were present; on the other occasions a single bird, either alone or with barn swallows. They may be seen in their beautiful flight passing back and forth in the air from one end of the pond to the other, or again rising higher in the air and measuring a larger area of the Garden.

\section{Bank Swallow \\ Riparia riparia}

Twice the presence of the Bank Swallow has been recorded. On May I8, I900, two birds were noted, and on May 16, I905, one bird. On the first occasion they were in company with barn and tree swallows. On the second occurrence the single bird was with barn and cliff swallows, one of a composite flock of twenty birds moving ceaselessly through the air and skimming the waters of the pond. 


\section{I38 BIRDS OF THE PUBLIC GARDEN}

\section{Cedar Waxwing Bombycilla cedrorum}

Cedar Waxwings, or Cedar-birds, are usually seen within the Garden each season. Some years three or four small flocks have come in succession. Other years a single bird only has appeared. In I907 no record of the species was obtained. The largest flock which has been noted was one of thirty birds on May 26, 1905. Twenty birds were seen on May 25, I904. Most of the occurrences of the species have been in May. Once, on March I4, in I902, a flock of six birds appeared. There have been but three appearances in April. Little disposition to remain in the Garden has been manifested. Indeed, in several instances a small flock has dropped in for a few minutes only. But as the Waxwing is a silent bird except for a lisping call which cannot be heard at much distance from it, and as the visits have proven fleeting, it is quite likely that more birds of this species have visited the Garden in the series of years than have attracted attention and been noted. 
There are two records of Cedar-birds in the autumn, one of a bird seen on the Common on October 13, I907; the other of a bird in the Garden on November 5, 1908. To these Mr. Maurice C. Blake adds the record of three birds present on October 5 , I904.

\section{Northern Shrike}

Lanius borealis

Mr. Francis H. Allen furnishes this record: "A Northern Shrike in the Public Garden, January I4, I9o I, singing."

This is the only record which has come to my knowledge during the years, I900-I908. But it is of interest to place here another and earlier record. Dr. Charles W. Townsend writes me: "I looked over my old journals and found under date of February 23, I876: '[My brother] saw a Butcher-bird or Great Northern Shrike on the Common. A year or two ago I saw a man shoot one here.' I remember the incident very well. The bird was on the Public Garden at the northern end of the pond, 
I40 BIRDS OF THE PUBLIC GARDEN

and a man employed by the city shot it. At that time several Butcher-birds had appeared and were feasting on the English sparrows, and the city employed a man to shoot them in order to protect the imported pets."

It would appear from this incident and testimony that in former years the Northern Shrike was a frequenter of the Garden and the Common as a winter visitant after the house sparrows had become numerous there. In the country neighboring Boston the species is now much less common than formerly, but in recent winters a Butcherbird has usually frequented the Fens.

\section{RED-EYED VIREO}

Vireosylva olivacea

The Red-eyed Vireo is not a common visitant to the Garden, yet no season has lacked at least one record. In three of the years a single bird only has appeared, I90I, 1902, and I903. In other three of the years of observation two birds successively have come, I904, 1906, and 1907. Probably 
eight different Red-eyes came in 1905, in which year five singing birds were recorded on May 27. Twice the arrival of the species has been on May I5 and twice on May I6. The arrival in other seasons has been between May I8 and 23.

There is no record of a bird remaining more than two or three days, except in 1908. In that year one, sometimes two singing birds were present from May 24 to June I, suggesting a not improbable nesting of the species. Mr. E. E. Caduc informs me that he heard almost daily a Red-eyed Vireo singing in the Garden on the Charles Street side up to July 3 of that year and another on the Common. As he left the city for the summer on that day, he was unable to carry the record further. No vireo's nest was discovered on the leafless boughs in the autumn by him or me. Four or five years earlier a beautiful, well-preserved nest of the summer was seen on the Common in the autumn and winter months following, to that extent testifying to a nesting of either the Red-eyed or the Warbling Vireo. 
I42 BIRDS OF THE PUBLIC GARDEN

\section{WARBLING VIREO \\ Vireosylva gilva}

The Warbling Vireo makes its appearance in the Garden to almost the same extent as the red-eyed vireo. In the case of this species, also, there have been three years, I901, I903, and 1904, when one bird only has been recorded. Probably four birds constitute the largest number which has been present in any one season, namely, in 1906. The earliest date of arrival has been May 9, in I900. The latest date on which a bird has been recorded was May 27, in 1905. In 1906 two birds, one of which sang much, extended their visit from May I5 to 26 , and may have nested within the Garden.

\section{Yellow-throated Vireo}

Lanivireo flavifrons

The Yellow-throated Vireo has appeared in five of the nine seasons of observation, twice in two of the seasons, a single bird on six occasions, and two birds on one occa- 
BLACK AND WHITE WARBLER I43 sion, namely, May 7, 1905, which is also the day of the earliest appearance. In the years I90I, I902, I904, and 1907 the species was not recorded. May $2 \mathrm{I}$ is the latest date on which a visitant has been seen, namely, in 1900 and 1903. One bird only has been heard to sing. No visitant has remained to a second day.

\section{Blue-headed Vireo}

Lanivireo solitarius

The Blue-headed, or Solitary, Vireo has been noted in four of the seasons only, one bird in I9OI and I903 respectively, and two birds in each of the years 1905 and 1907. Thus there have been six appearances of the species only, and these have occurred between May I3 and 2I. In neither instance has the visitant sung or remained over to the next day.

69. Black and White Warbler Mniotilta varia

The Black and White Warbler, or Black and White Creeper, may be relied upon to 


\section{I44 BIRDS OF THE PUBLIC GARDEN}

make several successive appearances in the Garden. Three or four visitants in a season constitute the rule. Twice the usual number were recorded in 1907 and again in I908. Many of the visitants remain three or four days. In 1908 a female bird was present from May I4 to I9, six days. The earliest appearance was on April 30, in I906, one bird. In 1902 the first visitant, a female bird, came on May I. In I908 the first visitant, a male bird, came on the same date. May 7 to 12 has been the usual time of appearance of the species. The migration has commonly extended to May $2 \mathrm{I}$ or 22 , sometimes, however, ending on May I7 or I8. In I908 it extended to May 25 , covering twenty-five days. On several occasions two or three birds have been present on the same day. Not infrequently the visitant has been in song. On account of the creeping habit of this warbler and its rather toneless song, it may be more easily overlooked than many other warblers, whose constant flittings among the boughs with only partially developed leafage are more likely to attract attention. 
70. Prothonotary Warbler

Protonotaria citrea

In the forenoon of May 20, I900, Miss Isabel P. George; while crossing the Garden, observed a small bird in bright orangeyellow plumage flitting in the air from the branches of willows which stand beside the pond, repeatedly sallying out over the water and returning again. It was no other bird than a Prothonotary Warbler. The observer remained to enjoy it for fifteen minutes, and its coloration and behavior were indelibly impressed upon her mind.

In the same forenoon at another hour Miss Calista S. Whitney, who was lingering in the Garden to enjoy the migrant birds, of which there was a large number on that day, also saw this bird and watched it for some time, noticing similar flittings out over the water of the pond from the willows standing on the shore.

Dr. Manning $\mathrm{K}$. Rand was a third fortunate observer of this rare warbler, and at the time similarly described its appearance 
I46 BIRDS OF THE PUBLIC GARDEN

and movements. Dr. Rand writes me that he saw the bird on May I9, the previous day.

The Prothonotary Warbler, upon the authority of Chapman's "Warblers of North America," wanders occasionally northward to Massachusetts. It has not been my privilege to see one, but the observations here recorded were made by the observers independently of each other, and as the records of careful and accurate observers are entirely reliable.

\section{Golden-Winged Warbler}

Helminthophila chrysoptera

In the largest migration movement of the year 1900, which occurred on May I9, as manifested in the Garden, a Goldenwinged Warbler came, a female bird. It did not remain to a second day.

\section{NASHVille WARBLER}

Helminthophila rubricapilla

The Nashville Warbler is an infrequent visitant to the Garden. In four of the nine 
seasons, namely, in 1902, 1904, I905, and I907, it made two successive appearances. In four other years it was not recorded. In I908 two birds were on the Common on May I2, a day of very large migration, but none was in the Garden. The earliest arrival of the species was in I902, May 5. In other seasons the first visitant has been noted on May I3 or I4. The second visitant of the season has three times come on May I9 or 20, once on May I5 and remained to the second day. The other visitants have been recorded on one day only. In three instances the bird was singing.

\section{Tennessee Warbler Helminthophila peregrina}

On May I6, I905, when the number of species within the Garden summed up forty-one and the number of migrants was nearly one hundred, a male Tennessee Warbler was seen. The bird was not singing. It moved among the branches of a large English elm.

Again, in I908, on May 24, a second re- 
cord of the species within the Garden was obtained. On that day a female bird was present. It was first seen in the European beech near the Everett statue, and upon a later round of the grounds it was observed in a small bed of rhododendrons growing near the pond and afterwards in saplings which stand close by the bed. Both times the bird was well seen at near range.

\section{Parula Warbler}

Compsothlypis americana usnece

The Parula Warbler, or Blue Yellowbacked Warbler, is seldom absent a day from the Garden during the period of its migration. The number of birds present on the same day has varied from one to a dozen. The presence of three to five birds at the same time is not unusual. On May 19, I907, thirteen birds were recorded. The earliest appearance of the species was on May 2, I906, a bird in song. The arrival season by season has usually been between May 7 and I4. The last visitants have not 
departed sometimes before May 27 or 28, although May 22 to 24 has been the time of their disappearance in six of the nine years. The last birds have sometimes been singing males and sometimes a lone female.

The species was more abundantly present in 1905 and 1907 than in other seasons, the larger number appearing after the middle of the month in each instance. This is true of other seasons also. The Parula Warbler is commonly in song. There were two singing birds on the Common on May I2, I908, while there were three in the Garden.

The first autumn records of the species were obtained in 1908, a Parula Warbler being noted in the Garden on October 9 and another on October I7:

\section{Cape May Warbler}

Dendroica tigrina

A male Cape May Warbler appeared in the Garden in the morning of May I I, I902, and remained four days, at times singing freely. He frequented one section of the 
grounds. So he could usually day by day be found there. If he wandered to another section, he did not fail to return again soon to his wonted area. He was not shy during his stay and constantly afforded fine opportunities for careful observation of his markings. His great activity of movement presented the only difficulty of remaining near him. He showed a preference for the trees which were as yet more thinly foliaged, the elms, the cottonwoods, and the willows, rather than for the maples, the horse-chestnuts, and the hawthorns, and was often in the lower branches. He was once seen on the turf at the border of a bed of yellow tulips.

On another occasion in the early morning, with desire for a bath he dropped down upon the granite curbing of a basin inclosing a small fountain and tried to reach the water, but it proved to be too far below the stone edging to permit him to make use of it. So presently, perceiving that he could not get his bath there, he flew to the heavily dew-laden grass and with shakings of the 


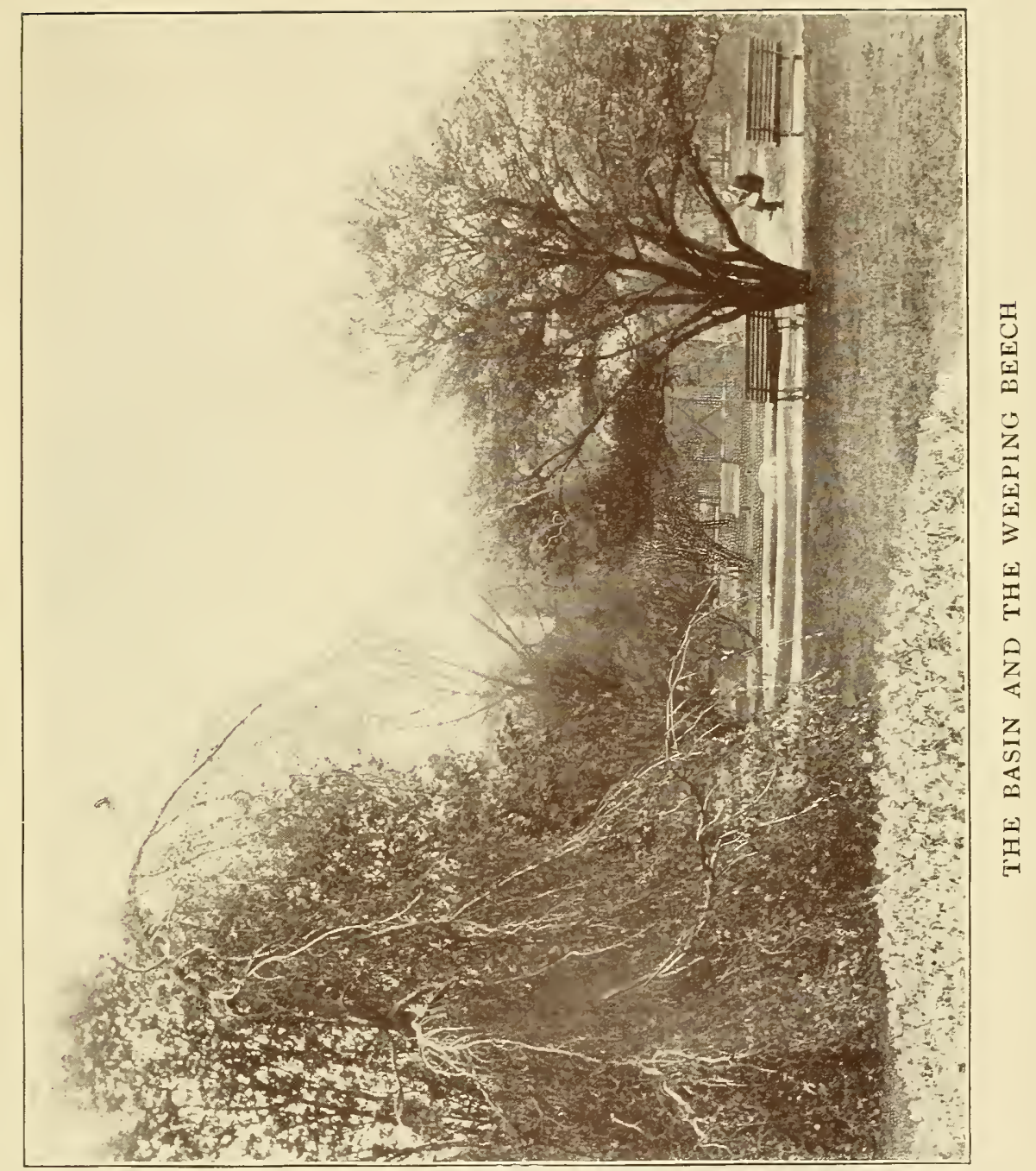



wings succeeded in throwing the dewdrops over himself and obtaining the refreshment he sought. Then well wetted, he rose into a double-flowered peach tree and in happiness finished his morning toilet. It seemed a pity that there was but one observer of this dainty proceeding, but so it was. Upon other days and at other times there were many interested observers, who availed of the rare opportunity of becoming acquainted with a full-plumaged Cape May Warbler often voicing himself in song.

A second record of the species was of a female bird seen on May 26, I905, and not remaining to a second day.

In I908 a third Cape May Warbler came to the Garden on May I6, a female bird, and was seen by a group of interested observers after I had discovered its presence. This bird moved through the Garden with exceeding restlessness and rapidity. It was first seen in trees of low growth near the Everett statue, from which it quickly moved into the large white willow at the northwest corner of the pond. Repeated momentary 


\section{I52 BIRDS OF THE PUBLIC GARDEN}

views of the little visitant were obtained, making its identification sure. It made constant sallies from the boughs into the air after the manner of flycatchers. Later it moved in the top of this and other trees in so hidden a way that it required patience and persistence to find it again. At length it passed by an extended flight over to an old willow in the vicinity of the Arlington Street Church. Quickly from there it rose into the air and apparently was leaving the Garden, as it took its flight out over Boylston Street and its buildings. But presently it was seen to turn in its course and come back into the Garden, alighting in the southeast quarter in an American elm. But hardly had it rested there, when it rose again and, passing over the centre path, lit in one of the large willows which stand beside the pond in the northeast quarter. Here it remained, restlessly moving among the boughs of this and other neighboring trees, furnishing ample opportunity for successively arriving observers to view it. The pursuit had been a lively one and had 
been carried to a successful termination, some young friends assisting much to keep track of the flights of the warbler as it passed through long distances of air from us. It was present upon this day only.

\section{Yellow WARBLER}

Dendroica cestiva

The Yellow Warbler, or Summer Yellowbird, becomes a somewhat common bird in the Garden during the month of May, but before the end of the month the last individuals have disappeared. It is not probable, therefore, that the species nests within the Garden. Yet there may have been exceptions to this statement unknown to the writer. The earliest appearances have been on May 3, in 1905 and 1906 . In other years the arrival has been between May 7 and Io, having been twice on May 8 and three times on May 9. The earlier birds disappear and are succeeded by others. This may occur two or three times. In two seasons only has the Yellow Warbler remained beyond May 24, the last bird usu- 


\section{I54 BIRDS OF THE PUBLIC GARDEN}

ally departing on May 21, 22, or 23. But in I904 three birds were present on May 26 and in 1908 two singing males were present up to May 27. There has been no extension of stay over this time.

Two, three, or four Yellow Warblers are all there are usually in the Garden in any one day, and many days one only has been present. But five birds were recorded on May 14, I907, three males and two females, and the same number on May 26, I908, four being male birds. The males sing.

\section{Black-throated Blue Warbler}

\section{Dendroica carulescens}

From two to four Black-throated Blue Warblers have been recorded in six of the nine seasons. In 1908 there were six visitants of the species. In I90I and I904 no bird was noted. The earliest appearance was on May 7, 1905, when a male bird arrived in song. The first visitants have variously come between May 7 and I9, but usually between May 9 and I3. The last one generally departs between May 2I and 
24. Many of the visitants have made stays of several days. In one instance a female bird, presumably the same bird, remained eight days, from May Io to I7, in 1902. Several times male birds have remained from five to seven days. It is usual for them to sing. One visitant was heard singing on the Common on May I2, I908.

\section{Myrtle Warbler}

\section{Dendroica coronata}

The Myrtle Warbler, or Yellow-rumped Warbler, regularly appears in the Garden. In 1903 but one visitant was recorded, a male bird in song on April 30. Usually from six to twelve birds appear successively in a season, one or two to four at a time. Seven were present together on May I9, I907. The earliest appearance of the species was on April I7, I902. The time of arrival has varied between April I7 and May I8, which late date was in 1904, when birds were present only from May i 8 to 20 . Late April and early May are the more usual times. The migration commonly extends 
I56 BIRDS OF THE PUBLIC GARDEN

to May 20 to 22. The latest record is of a male bird present on May 25, I905. Sometimes visitants have remained four or five days. The males are often singing. Occasionally a visitant has been seen or heard on the Common.

Quite as regularly the Myrtle Warbler again visits the Garden in October, and in about the same numbers as in the spring. Nearly twenty came successively in October, I908. During the last week of this month the last usually depart, but there have been two or three early November records, one being of five birds present on November 4, 1906, and another of one bird on November 9, 1903.

\section{Magnolia Warbler}

\section{Dendroica magnolia}

The Magnolia Warbler, or Black and Yellow Warbler, has been a visitant to the Garden in the spring to about the same extent as the Myrtle Warbler. The numbers of the two species have averaged very nearly alike, about sixty birds each in the 
period of nine years. In I90I but one visitant was recorded, a male on May 22. In I907 probably fifteen birds came successively. There were ten present together from May I9 to 22, eight males and two females. Most of the records are of a single bird or of two or three birds. The earliest arrival was on May 9, I902, three birds. First appearances have varied between this date and May 22. The middle of the month, May I2 to I6, is the more usual time of arrival. On either May 22, 23, or 24 the last bird usually departs. In 1907, when ten birds were present on May 22, but one remained on May 24, and this bird was not noted on the following day. In 1908 a male and a female were present on May 27, but were not noted later. It is not unusual to hear one of its forms of song.

\section{Chestnut-Sided Warbler}

Dendroica pensylvanica

The Chestnut-sided Warbler has been absent from the list of the season but once, in I904. Usually there is a fair representa- 
tion of the species, four to six birds being present in a season. In 1907 nine birds were recorded, six being present together on May I9, three males and three females. The earliest appearance of the species was on May 4, I906, a male bird. In three of the seasons the first comer has arrived on May 9, namely, in 1900, I902, and 1905. In 1903 there was but one record, two birds appearing on May 22, which is the latest date of the first appearance. Either on May 22, 23, or 24 the last visitant has departed. The presence of a female bird on May 26, 1906, forms a single exception. The records indicate that a visitant sometimes remains four days. Two birds were seen on the Common on May I2, I908. The males sing.

\section{I. BAy-BREASTEd WARBLER}

\section{Dendroica castanea}

There are two records of the Bay-breasted Warbler. On May 23, I900, a male bird was present in the Garden. It did not remain to a second day. And on May 22, 
I903, again for a day only, a female bird was seen.

The male bird was singing his slight song at the time of observation in one of the large willows about the pond. It was a day when fifteen species of warblers were present, including a Blackburnian and a Chat, and when four male scarlet tanagers were flashing their brilliancy about the pond. The female Bay-breast appeared with eleven other species of warblers, including two Blackburnians, a male and a female.

\section{Black-POLL WARBLER}

\section{Dendroica striata}

The Black-poll Warbler never has failed to appear in the Garden in the spring season, several birds at a time usually and in several successive flocks. The little flocks also remain usually several days. The largest numbers which have been recorded in any one day were nine on May 27, I905, and thirteen on May 27, 1908. The earliest appearance of the species was 
on May 7, I905, when one male bird was present. The next earliest date was May Io, in I904, a male bird in song. From May I3 to I7 is the usual time of arrival, and then commonly a single male bird has come. After the middle of May the small flocks appear, three to six birds. The last are still lingering when the season's observations have been closed, the time varying from May 27 to June 2. Some visitants probably remain five or six days or even longer. The willows about the pond are the favorite trees of this species.

The song is commonly heard throughout the migration season. On May I9, I908, a Black-poll sang an unusual song, as he flitted about through the top of the big white poplar on the Boylston Street side of the Garden. A few notes, sometimes only two, were given in the usual way, and then the song ran up like a Blackburnian warbler's, much accelerated to the end. Occasionally he gave the regular song, although somewhat abbreviated, affording a comparison of the two forms. The closing of 
the peculiar song when heard at a distance, strange to say, somewhat suggested a weak song of the downy woodpecker. Ten days later two Black-polls within the Garden sang a song resembling the chipping sparrow's trill, only shorter.

Mr. Maurice C. Blake furnishes three early autumn records of the Black-poll Warbler in the Garden in its migration south, namely, one of eighteen birds on September 24 and one of seven birds on October 5 , in 1904, and one of a single bird on September 8, 1905.

During the last five years and also in I900 I saw a few Black-poll Warblers in the Garden in October, and in 1904 and again in 1908 , the movement to almost the end of the month was continuous and abundant, ten birds being recorded on October I7 and thirteen birds on October 23, in I904, while in I908 nineteen were counted on October Io, twelve of them being among the branches of one sycamore maple, twenty-one on October I4, and seventeen on October I9; upon the intervening days in 
each instance the numbers were smaller. These figures indicate how abundant the migration of Black-polls was in the autumn of these two years, especially the latter. The latest lingering birds, two in number, were seen in 1900 on November 2.

\section{Blackburnian Warbler}

\section{Dendroica blackburnice}

The Garden has received a few visits from the Blackburnian Warbler. In six of the years of observation the Blackburnian has been present. In four of these seasons a second visitant, or two, has come a few days after the first. All of the records are of male birds except one. On May 24, I908, a female bird was present with a male. Neither remained to a second day. Usually the song has been heard. In two instances the visitant has stayed four and five days respectively; in the first instance, I900, from May I9 to 23; in the second instance, I907, from May I9 to 22. The earliest appearance of the species was on May I0, in I900. In four of the years a 
Blackburnian Warbler has been in the Garden on the nineteenth day of May, having arrived on that day. The latest date to which a visitant has remained has been May 24, in 1905 and again in 1908.

This warbler is usually in the larger trees - elms, willows, or maples - and in the higher branches. A very favorite tree of the species is a large, ill-shaped willow near Arlington Street and almost opposite the church. Here several of the visitants have been seen, together with other warblers. In 1907 the visitant frequented a large silver maple near the southeast corner of the pond, sometimes passing into other trees beside this; but during his four days' stay he was seen in this tree each morninga marked instance of chosen limitation of range while remaining.

On May 20, 1900, in cool and clouded conditions of weather a Blackburnian Warbler was seen upon one of the grassplots, finding his food on the surface. On the grass with him were also magnolia, black-poll, chestnut-sided, black-throated 
green, and Canadian warblers. There had been a thick northeasterly rainstorm the preceding day, and it may be surmised that the insect life on which these warblers feed had been washed from the atmosphere and the trees to the ground and was found there. The occasion afforded a rare opportunity to view these warblers in the open and below the level of the eye, as they moved about upon the lawns.

\section{Black-throated Green Warbler}

\section{Dendroica virens}

The Black-throated Green Warbler has not failed to come to the Garden every year ; usually several birds appear. In I905 two birds, both singing, appeared on May 7 , the earliest appearance of the species in any year. These were followed by four other birds successively at intervals, two male birds and two female birds, the last female coming on May 26, which is the latest date for the presence of the species. In this year, therefore, the migration covered twenty days. In I902 three visitants 
were present on May 9, but they did not remain. Usually the several appearances have been within the space of eight days, May I3 to 20. In a few instances the stay of the visitant has been extended to the second day, but usually the birds have remained one day only. It is not unusual to hear the song, and yet it is given but little. After a few repetitions the songster has commonly ceased singing, and it has been difficult to trace his presence longer. It has seemed sometimes as if the visitant must have left the Garden, perhaps seeking at once the white pines which this warbler loves so well. On May 12, I908, one was singing on the Common.

Three times a Black-throated Green Warbler has visited the Garden in October, once each season in 1904, I906, and I908, in all three instances on October 13 ; none remained to a second day. 


\section{Pine Warbler}

Dendroica vigorsii

The only visit in the Garden of a Pine Warbler, or Pine Creeper, which has come under observation, was on April 5, I903. It was seen upon the trees of the small island. A sharp drop of forty degrees in the temperature had occurred, and a brisk northwest wind was blowing; but the high temperature of the preceding day with fresh southwesterly winds had caused a new movement of migrants bringing with the Pine Warbler to the Garden several phœbes, two hermit thrushes, a swamp sparrow, and a further accession of robins. The visit was not prolonged to a second day.

\section{Palm WARBLer}

\section{Dendroica palmarum}

On October I7, I904, a Palm, or Redpoll, Warbler appeared in the Garden. It was unaccompanied by other redpoll warblers, either palm or yellow palm. The 
soiled whitish throat and breast and pure yellow lower belly and under tail-coverts made it certain that it was a Palm Warbler. The visitant remained mostly upon the grass during observation, wagged the tail but little, and gave its call-note repeatedly.

\section{Yellow Palm Warbler}

Dendroica palmarum hypochrysea

A little flock of Yellow Palm, or Yellow Redpoll, Warblers came in each of the years I90I, I902, and I903. The first visit was of three birds on May I to the Common; the second visit was of six birds to the Garden on April 23 and 24, one remaining to April 28; and the third visit also to the Garden was of three birds on April 29. The first company sang freely. No bird of the species was again noted in the spring until I908, when three birds appeared singly on April I5, 23, and 29 respectively, the second one on the Common.

There have been three autumn records for the Garden: one of a bird on October 
I68 BIRDS OF THE PUBLIC GARDEN

I9, I902; one of a bird on October I8, I904; and one of a bird on October I7, I906.

No explanation of the absence of the species in the spring during four years suggests itself.

\section{Prairie Warbler}

Dendroica discolor

The Prairie Warbler is a rare visitant to the Garden. Three visits have been recorded. The first was of a bird on May 23, I900; the second was of one on May I9, I905, in song; the third was of one on May I5, I907, and continued during the two days following. The last visitant sang much his song of many zees repeated rapidly. This bird frequented the group of large elms opposite the entrance from Newbury Street.

89. Oven-BIRD

Seiurus aurocapillus

Several Oven-birds, or Golden-crowned Thrushes, every year have visited the Garden, with two exceptions coming singly at first, and later often two or three birds 


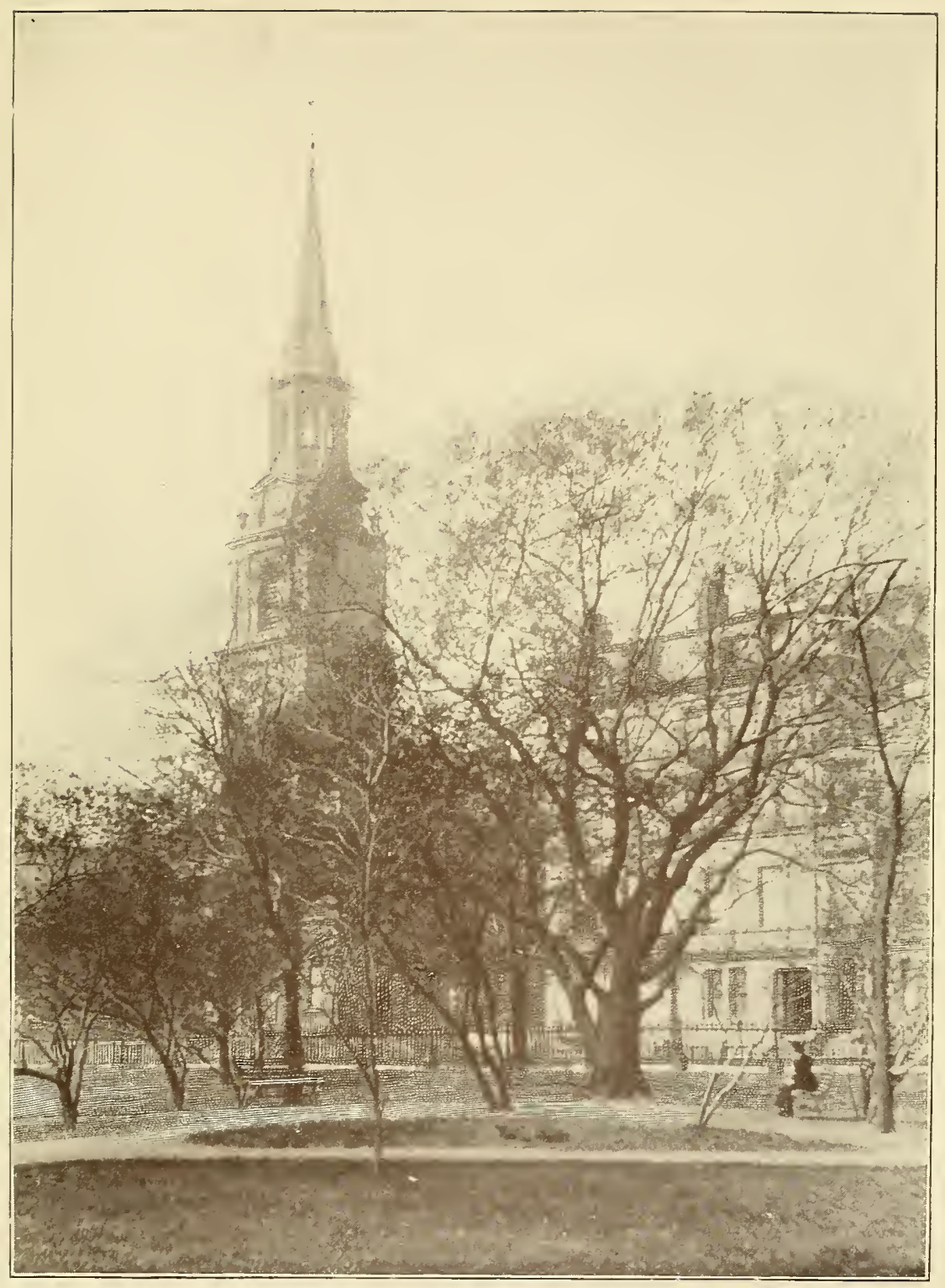

THE OLD WILLOW GROUP 

or more together. But five birds arrived on May I4, I907, and eight were seen on May I2, I908, one other being on the Common. Some of the visitants apparently make a prolonged stay. One bird in I900 was noted daily from May I4 to 2I, eight days; another in 1904 from May II to I7, seven days; another in 1905 from May I6 to 21 , six days; another in 1908 from May 13 to I9, seven days. The earliest appearance of the species was on May 7, I905, the most delayed appearance on May 2I, I903. In the seven other years between May 9 and I4 the first Oven-bird has come and been followed by others in succession to May 2 I to 26. The latest bird recorded remained to May 29, in 1907.

The song has been heard on many occasions. In one instance the songster was in shrubbery nearly opposite the Arlington Street Church, and on a quiet Sunday morning in May at an early hour earnestly gave his crescendo song again and again. Sometimes one has been seen to pursue its sedate walk on the sidewalk outside of 
I70 BIRDS OF THE PUBLIC GARDEN

the Garden, thus promenading the public street. The demure, leisurely walk of the Oven-bird, often taken at little distance from the observer, makes it an easy hird to identify as it moves under the budding lower branches of the great beeches or about the stocks of a cluster of shrubs.

Repeatedly when a bird has remained several days, it has been found morning by morning in the small section of the grounds where it was seen on the first day, seeming to roam only within a very limited area. So day after day, when it has been looked for in this area, it has been at once seen and for another day placed in the record. One such long-tarrying bird made the fence line on Arlington Street near Beacon Street its promenade and proceeded in its moderate way back and forth under the overhanging vines or about the near shrubs day by day for seven days. I have walked by this bird at only fifteen feet distance, and it paid me no heed. 
90. Northern Water-Thrush

Seiurus noveboracensis

Northern Water-thrushes visit the Garden in about equal numbers with the Ovenbird. The comparison is somewhat in favor of the Water-thrush. The species makes its appearance on about the same dates as the Oven-bird. Thus the earliest appearance was on May 7 , in I902. No first-comer has arrived later than May I7, which opened the record in 1903. In the seven other years the first Water-thrush has come between May 9 and I3. A single bird has always arrived first, and this has soon been followed by others. Five came together on May 15, 1905, and the same number again on May 12, 1908. Four or five days appear to constitute the longest time any ndividuals have remained. Such a stay has been made by visitants a few times. The latest birds have remained variously to May 20 to 27. The rather loud and clear song has often been heard.

The Water-thrush, like the Oven-bird, 
walks, but in so doing constantly wags its tail. It seeks the vicinity of the pond rather than the shaded areas under the larger trees and often walks on the stone curbing surrounding the pond in its desire to be near the water. It also seeks groups of trees or shrubs standing near the pond and their protection, and it frequently perches high in these to escape the intruder or to pour forth its song. In escape, when frightened, it often flies a considerable distance, showing a marked degree of fear. The Oven-bird, on the other hand, being less shy and seemingly unsuspicious of harm, seeks only the branches of a near tree and counts itself secure.

One Northern Water-thrush has been seen in the autumn in the Garden, namely, on October 8 and 9, in I908. Mr. Maurice C. Blake furnishes one other record, that of a bird present on September 24, I904. 


\section{I. Connecticut Warbler}

Oporornis agilis

A Connecticut Warbler visited the Garden on October I7, 1908. It was first seen in a bed of roses near Arlington Street and the centre path. From this it presently passed to a Pyrus Japonica bush and then into a near beech, giving occasionally a strong, sharp call-note. The next morning the visitant was seen on the opposite side of the Garden in a bed of hardy azaleas, from which it moved into other beds and then into a beech standing near. Its call-note, distinctive from that of the black-polls which were present, served to locate the bird when the observer was at some distance. The two following mornings it occupied the same section as upon the second day, being seen in a sycamore maple which was much frequented by the black-polls. The visit of this Connecticut Warbler, therefore, covered four days. 
92. Maryland Yellow-Throat Geothlypis trichas

The Maryland Yellow-throat is a quite common visitant to the Garden. Its earliest appearance in the nine years was on May 3, I905, when three male birds were seen. The preceding year the first bird appeared on May 4, a male bird in song. In other years the time of arrival has been between May 9 and 14. The period of migration has variously covered from ten to twenty-four days, the latter period in 1905 . In 1907 it covered seventeen days, May I3 to 29; in I908, twenty days, May io to 29. Usually the last birds of the species have passed on May 22 to 26. Five or six Yellow-throats have often been noted upon the same day, and such little flocks have sometimes remained several days. The song from time to time has been heard. Following their usual habit, the Yellow-throats are commonly in the larger individual shrubs or the shrub-groups, rather than in the trees, but sometimes they are in the larger trees 
with other warblers. They also frequent the flower-beds, moving among the blossoming tulips or bedded plants.

In 1908 seven male Yellow-throats were present in the Garden on May 12, and two others were seen on the Common. A female bird in that year remained from May 24 to 29 , being seen daily. In 1907 the latest lingering bird was a male in song, which departed also on May 29.

One autumn visitant has been recorded, a female bird, which was seen on October I7, I908, the same day which brought the Connecticut warbler and a northern parula warbler to the Garden. This bird gave no call-note and moved so quietly and hiddenly among the plants that it was almost overlooked. It did not remain to a second day.

\section{Yellow-breasted Chat}

Icteria virens

In 1900 the Yellow-breasted Chat gave promise of being a more frequent visitor to the Garden than it has since proved. In 
that year on May 9 one was present; again on May 18 one came and remained three days, and another arriving on the 2oth remained four days, presumably the same bird. So the Chat was recorded upon six days in succession in that season. On May 20 two were seen together. They were much upon the grass in the neighborhood of the Washington equestrian statue in company with other warblers, all of whom were finding their food upon or near the surface after a severe easterly storm.

It was not until the season of 1905 that another Chat was seen in the Garden. This visitor was present from May i6 to I8. It was first seen by Dr. C. W. Townsend on the first mentioned day. It frequented the northeast quarter, making use of groups of trees and shrubs near the pond.

In I908 again a Chat came to the Garden, arriving on May I2. Mr. Thomas S. Bradlee called my attention to it, while we sat upon one of the benches awaiting its appearance, for Mr. Bradlee had already discovered its presence. The bird came to the 


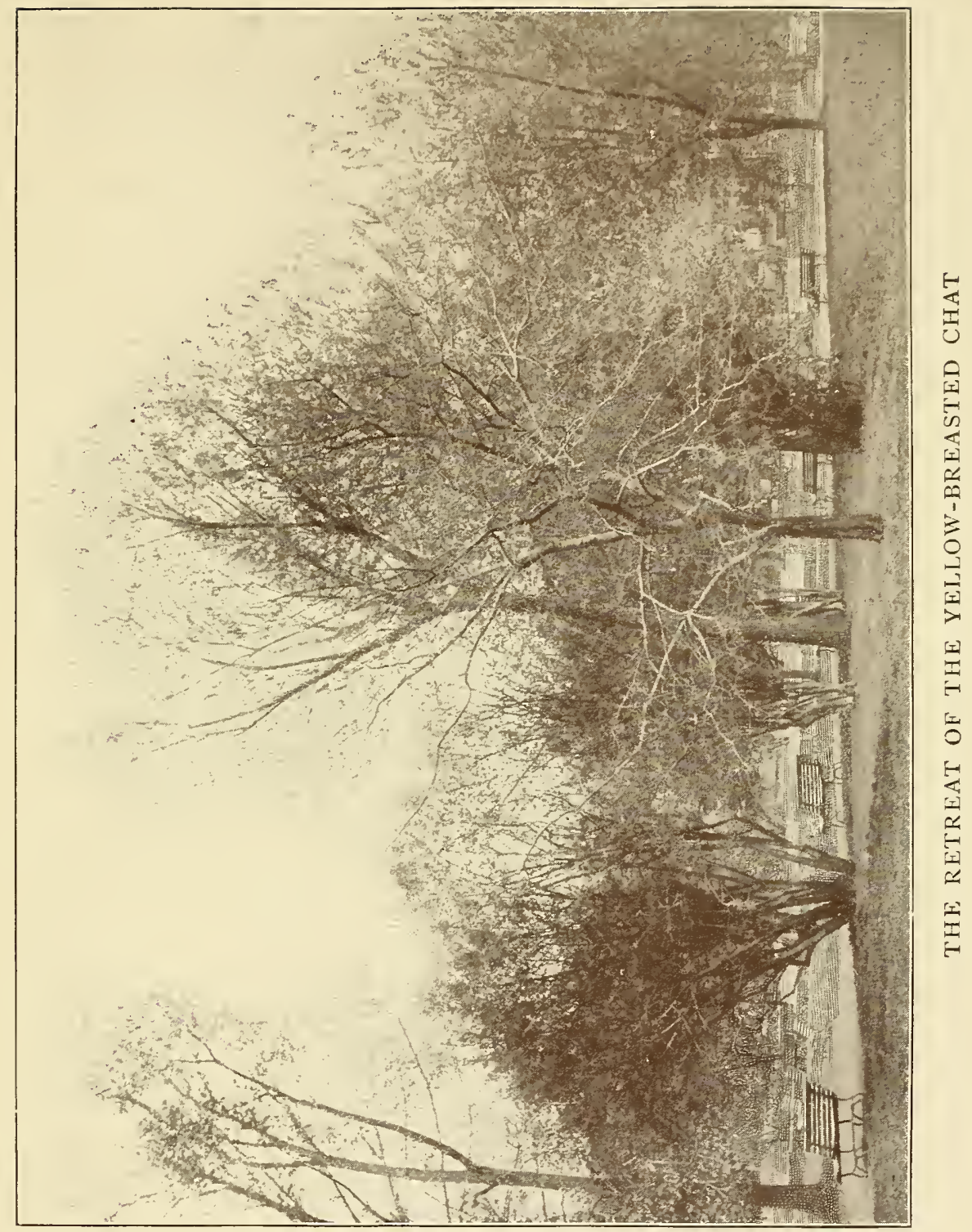



ground near us and immediately behind the garden-seat. This was in the vicinity of the Everett statue, the Chat making use of the European beech which stands near to conceal itself in when startled. It was not seen the following day.

Although Chats naturally seek the ground, shyness of persons who approach, going to and fro, usually drives the visitors much into the trees, and they show themselves very secretive and elusive. No one of the birds has been heard to sing or seen to perform any of the queer antics which conditions of wildness inspire.

\section{WiLsON'S WARBLER \\ Wilsonia pusilla}

The Wilson's Warbler, or Wilson's Blackcap, may be depended upon to make successive visits to the Garden, appearing in the middle of the month of May. May I5, 1905, marked its earliest appearance until the year I908, when a male bird came to the Garden on May io and a male and a female on May 12, while there was also 
a singing male bird on the Common. In three of the years it has first appeared on May I6. In I90 I its coming was delayed to May 22, and only two birds were noted in that season. The last visitants have usually passed on May 23 to 26, although in I907 the migration extended to the end of the month and one bird was present and in song on May 30. Commonly the male birds sing.

On May 19, I907, ten Wilson's Warblers were present, male and female, and five or six birds were recorded on the three days following. On some days of the migration period, which variously covers one to two weeks, a single bird only has been recorded, but there has been scarcely a day within the period of each season when one or several birds have not been present. This warbler frequents the larger trees about the pond, but may also be found in the groups of shrubs or in the English hawthorns. The black cap on the crown of the male bird, allowing the yellow of the forehead to show below it, is a distinguishing mark. 


\section{Canadian Warbler}

Wilsonia canadensis

The Canadian Warbler, or Canada Flycatcher, comes almost as regularly to the Garden and appears nearly as numerously there as the preceding species. It usually arrives a little later than the Wilson's and passes on with it. The earliest appearance was in I905, on May I2, when a male bird in song was seen More visitants were noted that year than in any other year of observation, five or six birds being present each day between May 17 and 24 and three remaining up to May 27. The male birds have been perhaps less in song than has been the case with the Wilson's warbler, although the song has not infrequently been heard. The visitants are likely to be in any of the tree or shrub growth about the Garden. The black necklace upon the yellow breast distinguishes the Canadian Warbler, the female birds wearing it as well as the male birds, only less conspicuously. 


\section{American Redstart}

Setophaga ruticilla

The American Redstart comes to the Garden and passes out again like all of the other warblers. It may be that occasionally a pair has nested there or on the Common. The earliest appearance of the Redstart was in 1905, when a male bird came to the Garden on May 9. In I908 three male birds came on May I2. Usually it has been quite the middle of May before the arrival has been noted, May I4 to I8. Three to five birds have often been present together. Six Redstarts were in the Garden on May 24, I908. Perhaps not more than a dozen birds have appeared in any one season; sometimes only four or five.

The male birds sing freely. The visitants frequent the larger and taller trees. Sometimes a young male in a plumage resembling that of the female has been seen singing like the adult male. In 1907, and again in I908, a Redstart was singing in the Garden up to the end of May, having 
been present eight or ten days, but he then disappeared.

One late autumn migrant has been recorded, namely, a young male or a female bird on October I2, I907.

\section{American Pipit \\ Anthus rubescens}

No spring records have been obtained. The species is a much rarer migrant through New England in the spring than in the fall.

On October 23, I904, an American Pipit, or Titlark, was heard calling as it passed over the Garden in the early morning. On October 13, 1907, a flock of eleven birds was counted, as they passed in flight, and again on October 19 of the same year another flock of twenty-one birds as they flew over. On October 27, I908, a single Pipit was seen flying over southward.

$$
\text { 98. Catbird }
$$

Dumetella carolinensis

Catbirds regularly come to the Garden and pass on during a period of two or three 
weeks. The earliest arrival of a Catbird was in I906, on April 30, one bird. Several seasons their appearance has been delayed to the middle of May, May 12 to I5; both in 1907 and 1908 it was upon May I2. In 1905, and again in 1907 and I908, the visitants were comparatively abundant. Probably twenty individuals in the first two named years and sixteen in the last year paid the Garden a visit, some remaining several days. Thirteen birds were recorded on May I9, I907, and nine were seen on May I2, I908. Usually not more than four or five are present at the same time.

Catbirds are late in getting away, May 23 to 25 usually marking their disappearance; in 1907 one bird remained to May 28, and in 1908 a bird in song to May 26. Occasionally only has the song been heard. Usually the visitors are silent, the call seldom having been heard. Following its bent for hiding-places, the Catbird seeks the screen which the shrubs growing close to the ground or the beds of rhododen- 
drons furnish, and it slyly emerges therefrom when it feels it safe to do so.

Dr. Charles W. Townsend furnishes an interesting winter record of a Catbird seen in the Garden on December 22, 25, and 27 in I904, it having been reported as present previous to the first mentioned day.

\section{Brown Thrasher}

Toxostoma rufum

Brown Thrashers visit the Garden in numbers somewhat fewer than the Catbirds, but the period of their migration, as evidenced there, is more extended. It has run over three weeks in five of the years, and in 1905 it covered thirty-three days, namely, from April 25 to May 27. The Thrasher appears earlier than the Catbird, often by a week or more, never having been later in arriving than May 7. The time of its appearance is in the first week of May, when not in the lảst week of April. Yet the last birds are quite as late in moving on to their breeding-haunts as are the Catbirds, May 22 to 27 variously marking the 
I84 BIRDS OF THE PUBLIC GARDEN

day of their disappearance. Probably not more than ten to twelve individuals in any one season visit the Garden. Not more than six birds have been noted on the same day. Sometimes a Thrasher has given itself over to song for a time in the early morning, perched high up in the top of a tree among the slender branches, where its form could be seen.

In 1907, which was the year of greatest abundance of the species, a tailless bird appeared on May I5, when four or five other Thrashers were present, and was seen for seven successive days. It could take short flights apparently as well as the other Thrashers and did not remain beyond their departure. The Thrashers conceal themselves very successfully in the thicker shrubs or hawthorns and remain silent most of the time, but they take advantage of quiet conditions to drop to the ground to feed. 
IOO. House WREN

Troglodytes aëdon

The House Wren had not been observed in the Garden until I906. On May I3 of that year one was seen, but it was very elusive among the planted beds and the shrubs. In 1907 two House Wrens were seen, one on May I4 and another on May I8. Visitants in earlier years may quite possibly have been overlooked. The birds recorded appeared in comprehensive migratory flights, when the number of species and individuals present was large.

\section{IOI. WINTER WREN \\ Nannus hiemalis}

Mr. Francis H. Allen furnishes a record of a Winter Wren in such proximity to the Common in a recent year that it seems not inappropriate to include the species in the local list. He states that the Wren was within the Granary Burying-Ground inclosure on April 25 and 26, I898. 


\section{IO2. Brown CReEper}

Certhia familiaris americana

A few Brown Creepers in the Garden are recorded each year, both in the spring and in mid-autumn. The earliest appearance of the species was in 1905, when on March 20 two birds came and remained during four days. ${ }^{1}$ In other seasons the Creeper has first appeared in April : one on April 7, I904, on the Common; one on April Io, I908; one on April I5, I905, on the Common; one on April 22, 1907, which remained six days, presumably the same bird. These firstcomers have usually been followed by others a few days later. In I905 eight birds were seen on April 26, and it may be that fifteen different individuals visited the Garden that season, the period of migration extending from March 20 to May 3, or forty-five days. The latest birds were present in 1907 , three on May I3. In 1900 two Creepers were present on May 9. This

1 In 1909 a Creeper was present on March 88 for one day only. 
was the day of my first visit ornithologically to the Garden, and the first bird seen and recorded on the occasion was one of these two Creepers. I quickly detected after my first observation the richness of the birdlife present.

Again in October the Brown Creeper regularly appears in the Garden in its southward migration, one or more birds successively, usually after the middle of the month. On October 26, I906, six birds were present. As the visitants are quite as likely to be upon the large trees which border the Garden or which stand in the streets which bound it as upon the trees within the grounds, it is probable that more Creepers have been visitants than have been seen and recorded.

In 1908 a Creeper appeared on October II ; another was present from October I4 to I6; another from October 22 to 28 ; another from November I to 8, being heard in song on the last two days of his stay; and a last one was seen on November I9. 
A few Brown Creepers have been noted on the Common.

Mr. Maurice C. Blake furnishes one early autumn record, that of a Brown Creeper present in the Garden on September 24, I904.

I03. White-Breasted Nuthatch

Sitta carolinensis

On May 19, I904, a White-breasted Nuthatch had come to the Garden and was heard singing. No other birds often in company with nuthatches were present. It was a cool, clouded day, with a maximum temperature of $52^{\circ}$ following an easterly storm.

On April 7 of the same year a female bird had been seen on the Common with a brown creeper and a hairy woodpecker as companions, working over the trees on Monument Hill.

\section{I04. RED-BREASTED NuthatCH}

Sitta canadensis

No spring record of the Red-breasted Nuthatch has been obtained. 
But in October, 1906, there was a most unusual visitation of this species to the Garden. On October I 4 and the three days next following, the first bird was seen; on October is three birds were present; on October 2I, five, all being seen together in one maple tree; on the day following, the number was reduced to two, and one remained four days longer, to October 26. Thus for thirteen successive days Red-breasted Nuthatches were present. A little company of golden-crowned kinglets, chickadees, and brown creepers, also an unusual occurrence, was present at the same time. After an interim, again on November 3 another Red-breasted Nuthatch came, accompanied by two golden-crowned kinglets.

In I9o8, on October I2, a single bird was present, but it did not remain to a second day. On December 29 of that year Mr. E. E. Caduc informs me that a Red-breasted Nuthatch was seen by his friend Mr. Potter, at the head of Commonwealth Avenue. 
I90 BIRDS OF THE PUBLIC GARDEN

\section{I05. ChickadeE \\ Penthestes atricapillus}

The Chickadee is an infrequent visitant to the Garden in the spring. One was noted on March 28, 1903. Two, remaining over from the winter, were present in March, I904, and also in March, I907, and then disappeared. In I905 two appeared on March 3I, and the song was heard. In the same year two were noted on April I9, and one came and was in song on May 13. In 1907 one was present and singing from April 25 to 29, and in 1908 a single bird was seen on April 9. These are all of the spring records.

In the autumn Chickadees are much more in evidence, as they quite regularly appear in the Garden and continue their stay into November; and, as already intimated, on two occasions two birds remained through the winter and were seen at intervals up to the end of March. Sometimes small flocks have appeared in October which numbered four, five, or six birds. 


\section{I06. Golden-Crowned Kinglet}

\section{Regulus satrapa}

Like the chickadee, the Golden-crowned Kinglet is an infrequent visitant to the Garden in the spring. In I9or one was noted on May I. This bird was on the Common. In 1902 one was seen on April 21. In I905 one came on March 29, a male bird with a beautiful orange-centred crown, and another came on April 28. In 1906 one was seen on April 20. In 1907 two appeared on the Common on April 23, and one was in the Garden on April 27 and 28. In I908 a female bird came to the Garden on April 28 and was seen in the elms of the Beacon Street mall on that day and the following day. In the last two instances only has the visitant remained more than one day.

In October more Golden-crests have been noted than in the spring, and no autumn has lacked one or more records. In most instances the visitants have remained several days, as in 1905 one was present from October I 8 to 20 ; in 1906 there were three 
192 BIRDS OF THE PUBLIC GARDEN

from October 16 to 19 ; in 1907 one from October $I_{5}$ to 22 , and two from October 27 to 30 ; in 1908 three from October 20 to 23. November 4 is the latest date on which a Golden-crowned Kinglet has been seen.

\section{I07. Ruby-CROWNED KINGLET}

\section{Regulus calendula}

The Ruby-crowned Kinglet has not failed to appear in the Garden each spring, usually two birds singly in succession. But in I901 three birds came on May 7, following one on April 30; and in 1907 four birds were present on May 7. The earliest dates of arrival have been April 23 in 1903 and I908, a single bird in each instance. The last migrants have usually passed by the end of the first week of May, but in 1904 and 1907 one was present on May I7 and I 8 respectively. A Ruby-crown has in no instance remained longer than to a second day and usually has stayed but one day. The migration has covered variously from seven to thirteen days. This very sweet little songster has often been heard singing 
his exquisite song, both in the spring and in the autumn.

On several occasions in the autumn Ruby-crowned Kinglets have come to the Garden. One visitant in song was present on October 16, I902; one in song on October 20, I903; one also in song on October 22 and 23, I906; and in 1908 one on October I4, followed by two on October 20, one on October 22 and 23, and finally one on November 5 .

\section{I08. Blue-gray Gnatcatcher}

\section{Polioptila carulea}

In the early morning of October 22, I904, upon entering the Garden on the northerly side the frequently repeated calls of a small bird not familiar to the ear attracted instant notice and led me to a beech tree from which they proceeded. Here a little bird as active as a kinglet, or even more active, was flitting among the boughs and proved upon examination to be a Blue-gray Gnatcatcher, a bird very rare within the bounds of Massachusetts. It had as companions 
I94 BIRDS OF THE PUBLIC GARDEN

black-poll warblers which were searching through the leafage for their food. The Gnatcatcher repeatedly made sallies forth for insects somewhat after the manner of the flycatchers. It at length flew from the beech to a sycamore maple, alighting near the top and gradually working down by successive flittings to the lower branches and even to the ground. It made noticeable displays of the white outer tail-feathers by spreading the tail as it flitted. The bluish gray color of the upper parts was clear and distinct in hue. It ceased not to give its call-note, by which as it moved from tree to tree it could be located. A southeast rainstorm with warm winds of almost gale force had raged the day previous, and doubtless had brought this rare visitant along from its more southern range. It was not seen or heard the following day.

\section{I09. WoOd THRUsh}

\section{Hylocichla mustelina}

The Wood Thrush was first seen in the Garden in 1906. Brief visits were then 
made by two birds successively. The first came on May 7, and the second on May I3; each bird remained but one day. The following year, 1907, two birds were present on May Io and were seen in the morning in company with hermit and Wilson's thrushes. In the late afternoon my sister, Miss Mary A. Wright, and Miss Isabel P. George heard one of these Wood Thrushes sing beautifully its evening song. Another bird appeared on May 13 and remained during four days.

These Wood Thrushes have kept rather more in the seclusion of the shrubs than the other thrushes which visit the Garden have done, and they have shown themselves less on the ground than they. No individuals were seen in the season of 1908 .

\section{IO. Wilson's Thrush}

Hylocichla fuscescens

The Veery, or Wilson's Thrush, is a regular visitant to the Garden. In 1906 only one bird was noted, which appeared as late as May 23. But usually several birds come 


\section{I96 BIRDS OF THE PUBLIC GARDEN}

in succession. In 1904 a Veery came on May 5, and the migration continued to May 20, the succession probably numbering six different birds. In I905 the first Veery came on May 3, and the migration continued to May 22, an equal number of birds coming in succession. In 1907 the same number came between May Io and 20. In 1908, strange to say, the same number again appeared, arriving between May 12 and 24. In 1903 four Veeries came on May 22 and passed on that night, the only birds of that season.

The song has been heard, especially upon a damp day, audible above the din of the city. Usually the species is silent. The Wilson's Thrush is very likely to be under the shadow of the beeches, which offer protection by their low, spreading boughs, and whose expanding leafage very closely matches the tawny backs of these thrushes.

One Veery was seen on the Common on May I0, I907, and one on May I2, I908; each occasion marked the first arrival of the species to both the Common and the Garden. 


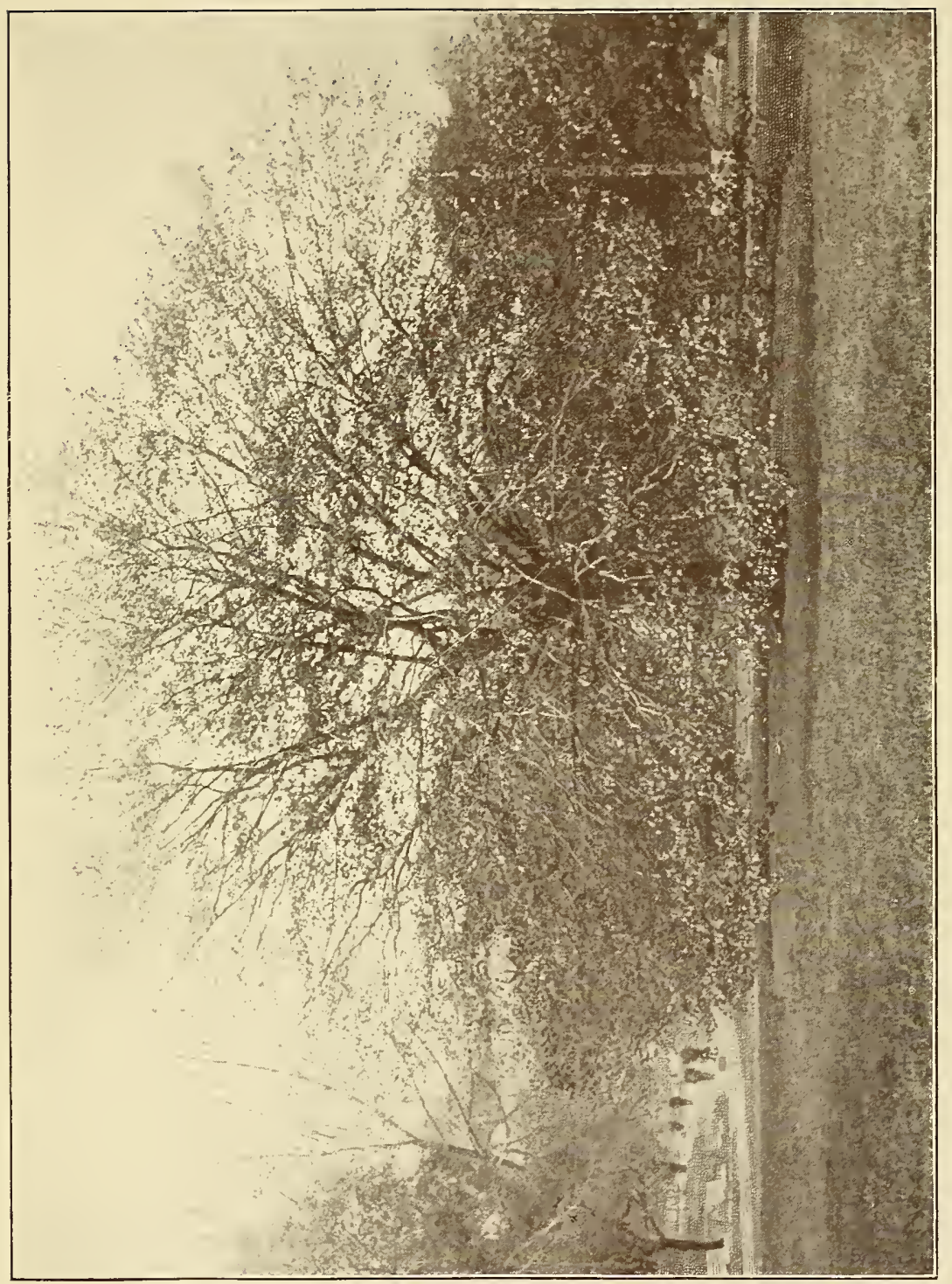

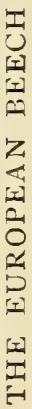





\section{Gray-CheEked Thrush}

\section{Hylocichla alicice}

Several records of Gray-cheeked Thrushes, or Alice's Thrushes, which have been well seen, have been obtained, beginning in I900, when one was present on May I 5 and two others came on May I8 and continued their stay during seven days through an easterly storm. In I90I one bird was present on May 22; in 1903 one was seen on May 20; in 1904 the visitant came on May 23; and in 1905 one on May 22, followed by another on May 25 which remained to the second day. In I908 a Gray-cheeked Thrush arrived in the Garden on May I7; two others came on May 24; and these were followed by one other on May 27 which remained over another day.

These records show that the Graycheeked Thrush arrives later than the other thrushes except Bicknell's, and has usually made but one day's stay. 
I98 BIRDS OF THE PUBLIC GARDEN

\section{I2. BICKNELL'S THRUSH}

Hylocichla alicice bicknelli

On three occasions a Bicknell's Thrush has been well seen in the Garden. In I904 one appeared on May 28 and was seen both on the ground and on boughs of the trees. The olive-backed thrushes had already passed on. In I905 one came on May 2I, when two olive-backed thrushes were also present. The smaller size, entire absence of buff tint and rather browner tinge of the back distinguished it from its near relatives. In I908 one came on May 27.

Dr. Charles W. Townsend furnishes an interesting fourth record. He writes: "On June II, I906, I noticed a male bronzed grackle picking at a dead bird in the Garden near the Ether Monument and when disturbed walking off, holding the dead bird by the neck. The bird proved to be a female Bicknell's Thrush and is now in my collection (cat. no. I257). It was perfectly fresh and apparently recently killed."

Mr. Maurice C. Blake furnishes one 
autumn record of a migrant southward, namely, a bird well seen by him in the Garden on September 24, I904, giving calls and snatches of song.

\section{I3. Olive-Backed Thrush}

Hylocichla ustulata swainsoni

Swainson's, or the Olive-backed, Thrush visits the Garden regularly, from six to a dozen birds appearing each year. In 1905 the first bird came on May 7. The usual time of arrival is May I3 or I4. In 1907 the earliest comers were seen on May I8, four birds. Six birds present upon the same day have been twice recorded, namely, May 20, I902, and May I5, I905. On the former occasion one bird sang the full song many times. On the latter occasion the number was not diminished for three days, and two birds recorded daily up to May 2 I may have been two of the little flock of six remaining seven days. The last birds linger variously to May 22 to 25 . One was present, however, on May 30, in I907, and one on May 28, in I908. The strongly buff col- 
oring on the head and throat of these birds established them surely as Olive-backs.

The song is rarely heard, and the callnotes are given infrequently. But on May I8, I908, an Olive-backed Thrush in a beech which stands near the Everett statue sang without ceasing for a half-hour or more, quite as he would have sung in a White Mountain forest such as he loves so well. When I had passed through the grounds and returned again to the vicinity of this beech tree, the bird was still singing.

\section{4. Hermit Thrush}

Hylocichla guttata pallasii

Of all the thrushes the Hermit Thrush is by far the most abundant visitant to the Garden. It comes the earliest and in considerable numbers, and the migration in some seasons has extended over a long period. For instance, in 1902 a bird appeared on March 13 and remained two days. Another came on March 24 and also remained two days. The last bird of that season passed on May II. The period of 
migration, therefore, was sixty days. In I905 the first bird appeared on March 29. This bird was reported by Dr. C. W. Townsend, and the last bird of the season passed on May 8. The period covered was fortyone days. In 1907 the first bird was seen on April 2, there being two others on the Common, and the last bird passed on May 14. The period covered was fortythree days. In 1908 the first bird appeared on April 7, and the last bird passed on May I4. The period covered was thirtyeight days.

In 1905, and again in 1907, the records indicate that probably forty Hermit Thrushes passed through the Garden. Fourteen birds were present together on April 20, I905; twelve were seen on April 26 after the former flock had gone; and ten were counted on May 3 after another interval of absence. In 1907 twelve were recorded on April 23, and twelve again on April 26, one only having been seen in the intervening days. In 1908 probably more than sixty Hermit Thrushes came to the 
Garden and the Common. On April I5 thirty were counted in the Garden, and one was seen on the Common. On April 23 twelve were in the Garden, and six were on the Common.

On May 6, I908, a Hermit came to the Garden which was very dull in color. This bird was seen each day up to May I4. It occupied the same small section of the grounds, the corner formed by Beacon and Arlington streets. Here it was seen every morning for nine days. On the r2th day four others were present for that day only, but the long-lingering bird, recognizable by its coloration, was seen by itself on that day and continued its stay two days beyond their departure.

A small flock of Hermits which came to the Common on April 16, 1908, remained about the band-stand for nine days; they were often seen close about its base as well as on the lawn around it.

Hermit Thrushes are also present in the Garden every year during the autumn migration. In I900 one remained from Oc- 
tober 25 to 28 . In I90I five were present on October 27 ; two remained another day. In 1903 five were noted on October 21 , and one was seen on November 8. In 1904 twelve passed in succession between October I6 and November 6. In 1907 five were seen on October 24, and the migration extended to November 8. In 1908 the first autumn migrant appeared on October I3, and the migration continued to November I9; nearly thirty individuals passed through in succession.

The November Hermits of that season clung very tenaciously to a group of trees and shrubs near the northeast corner of the pond. Three were here seen on the first day of the month, and three on the nineteenth day, after which no Hermit was seen within the Garden. Accretions to the number upon some days of this period indicated successive flights of the species southward even up to November 18, for five birds were present on that day. On November 7 one of the birds sang sweetly, but in suppressed tones. These Hermits were singularly 
tame, allowing one to approach as near as ten feet or to pass under them when perching, and they showed none of that shyness which belongs to the species in its nestinghaunts.

Once only in the spring has the song been heard, and then it was repeated several times clearly and came as distinctly to the ear as it is heard on the bird's breedingground in the White Mountains. This occurred in the early morning of April 2I, I902. Upon the same morning, it may be worth while to mention, a Hermit Thrush had been seen at the break of day in the back-yard of a house on Pinckney Street, and viewed with wonder at its choice of so confined and unnatural a resting-place. One of the several call-notes of the species is occasionally given, but rarely.

The Hermit Thrushes which visit the Garden are usually in plain evidence, of ten showing little timidity as they run upon the ground, pick their food, and take short flights. When startled from the ground the flight often is merely up into the branches 
of the tree above them or across an open space to some neighboring tree. As they are in the Garden before the leafage has appeared, it is easy to find them if resting upon a bough, as they at intervals quietly lift the tail. But commonly they are upon the ground.

\section{5. AMERICAN ROBIN}

Planesticus migratorius

The Robin is one of the three established summer residents in the Garden, the others being the bronzed grackle and the Baltimore oriole. Like the grackle, the Robin has become an abundant resident. The records of 1900 show that only three or four pairs of Robins were then nesting within the grounds. The number did not increase in the two years next following. But in 1903 ten pairs were nesting; in 1904 , eighteen pairs; in 1905, twenty pairs; and in I906, twenty-eight pairs. As in the case of the grackles in 1907 , so also the Robins were fewer in number in that year; twenty pairs, so far as could be ascertained, nested. 
In 1908 the number of nests located in May was twenty-five.

The Robin is one of the earliest birds to appear in the spring. A single male bird commonly arrives first, and the same morning it is usual to see several song and fox sparrows and a grackle or two. The earliest date of arrival of the Robin was in I908, in which year one came to the Common on March 12. In 1902 and 1903 the arrival was on March I3, on which day in each of those years two male birds came to the Garden. ${ }^{1}$ In I90I and in I904 the arrival was on March 24; in 1905, on March 18 ; in I906, on March 28; in I907, on March 2I ; a single bird came in every instance. If the arrival of the first bird be unusually early, commonly it is a week or ten days before it is joined by a few companions. Then successive additions are made to the flock of nesting birds even up to the early days of May.

${ }^{1}$ In 1909 two robins arrived on March I 5. A song sparrow preceded them by one day. They were joineci by a third robin on March 2I, and by four others two days later. 
Occasionally a migrating flock flies in and alights, it may be perching and cackling noisily in the larger trees, or spreading out upon the ground and running and chasing actively. One such flock in the Garden, it was estimated, numbered two hundred and fifty birds. It came on April Io, 1907. One of about twenty birds appeared on one piece of lawn on April 8, 1905. And another flock of similar size passed over in flight on April 7, 1908. Other flocks at other times have been seen. These appearances have been an hour or two after sunrise, and, as such flocks do not remain but rise again on wing and depart, the occurrences are confirmative of the idea that the Robin is a day-migrating bird.

Toward the end of March or in early April some female birds arrive, but it is well on in the month of April before many females have joined the males and nest-building begins. Many nests have been built or are building when May opens, but some pairs prove to be even later in their homemaking. 
The males which come first seem not to give themselves over to song, but they are heard occasionally singing. Bleak winds continue for many days after the first mild spell of weather which inspired the early comers, and the temperature falls on many mornings considerably below the freezing point. So these earlier birds much of the time lack incentive to sing until the warmer mornings come. Then they will be heard in chorus in response to higher ranges of temperature and the arrival and presence of the females. This chorus singing in all its combined power, however, occurs in the very early morning, indeed before sunrise. So, should you remark in early May to a patrolman whose beat is through the Garden, "I do not hear the Robins sing much," he will reply, "You should have been here about 3.30 o'clock this morning; that is the time they sing." Some birds are inspired in the later hours of the morning, but the universal song is given only at the early hour.

In October a few lingering Robins are 
found in the Garden, and some small flocks call there on their southward flight. One or two birds have remained in several of the seasons until the middle of November. In I903 and I904 the last one was seen on November I5. In I905 the last bird stayed one day later. In I908 two were present on November I8. Dr. Charles W. Townsend furnishes a record of two Robins in the Garden in the first week of December in I904. For eight months of the year, therefore, this "friend of man " and cheery, useful companion is present with us.

\section{I6. BLUEBIRD}

Sialia sialis

Bluebirds make very short visits within the Garden. One or two may be seen and heard for a brief time occasionally, as they perch on one of the trees, having alighted on their way further. On one occasion, March 26, I905, a flock of eleven birds made a short stay, and on March 28 a flock of eight birds lit, while on the same morning twelve others were noted as they 
flew over. The only instance of a pair tarrying, as if it might have intended to nest, was in 1902, when a pair remained in one section of the Common, that which lies nearest to Park Square, from April I to I4, and then disappeared. They were seen daily during those fourteen days. The earliest date of the Bluebird's arrival has been March 14, in 1902. ${ }^{1}$ Other dates of arrival have been March 15, I6, I9, 21, and April 4 and 5. Some visitants have appeared in May, apparently drawn along in the larger migratory movements. Thus in I902 one was present and in song on May 9, and another on May II. In I903 one came on May I9. In I904 two male birds were seen on May 5. In I905 a female bird appeared on May 16, and another came on May 20. In I906 a male bird was present and singing on May 20. In I908 a male bird was on the Common on May Io.

There are four late October records of

1 In 1909 Mr. E. E. Caduc informs me that he saw a male bluebird on the Common, on Monument Hill, on March 14. A blue jay was also present. 
the Bluebird. A single bird was recorded on October 20, I9OI; one on October 26, I904; one on October 26, I907; and on October 24, 1907, a flock of fourteen birds was seen flying over westward. In I908 the autumn visitants were all November birds; eight passed over on November I, and three were seen perching on the Common on November I2.

The Garden, therefore, scarcely constitutes a way-station for this species, as no Bluebird has been known to spend the night therein, or indeed pass an hour within the grounds. They make only fleeting calls and continue on their way; or in many instances alight not at all, but pass over in their migratory passage; for the Bluebird is one of the few species of small birds which migrate by day. 


\section{INTRODUCED SPECIES}

I. House Sparrow

Passer domesticus

The House, or English, Sparrow was successfully introduced into Boston by provision of the city government in the year I869 after an unsuccessful effort made in the preceding year. From that time dates its occupancy of the Common and the Public Garden and its spread throughout the city and thence to suburban cities and towns and thus more and more widely. Mr. William Brewster in his "Birds of the Cambridge Region," p. 65, says of his first observation of these sparrows: "I remember spending the greater part of a cold morning in December, I869, looking for the alien birds in Boston. On this occasion I failed to find any of them on the Common, but near the pond in the Public Garden I finally came upon six or eight huddled together in the top of a leafless bush. During 
the next three years they became numerous in Boston, and in 1873 they began to invade Cambridge, appearing first at Harvard Square and in Cambridgeport. A few were seen in the immediate neighborhood of our own place the following year, and in I875 a pair nested, for the first time, in our garden."

So now the House Sparrow we always have with us. It abides in abundance. But it seems as if the species locally had been somewhat on the decrease in the last few years. It is known that the parent grackles destroy some of the young sparrows, because this has been witnessed by a number of observers in June at the time when the grackles' young are first out of the nest and seeking food, and when also the young House Sparrows are clumsy of movement and fall easily a prey. I suspect the provocation proceeds from the parent sparrows who may in their rude way steal the young grackles' food for themselves or their young, and that the killing is done in retaliation and in the interest of the young grackles, 
2 I4 BIRDS OF THE PUBLIC GARDEN

for I do not learn that it is witnessed at other times. There is some decimation of the House Sparrows in the Garden in this way.

Noisy and pugnacious as they crowd together, yet these sparrows have appeared usually to give the small migrant birds little annoyance. Occasionally I have noted a marked exception to this statement, when, it may be, a warbler, provoking animosity by the challenge of its song, has been fiercely chased about for a time by an angry sparrow and sometimes has flown out of the Garden. Such a pursuit is more likely to happen upon a day when there are but few migrants present, or in the earlier part of the season, and it seldom occurs. Later in the season the House Sparrows seem to become wonted to the presence of the migrant birds and more willing to share the grounds with them.

In the early morning hours I have found them less noisy and less in evidence to sight than in the forenoon, when they are gathered in larger numbers from the neigh- 
boring streets to bathe at the edge of the pond or the fountains and sun themselves on the grass-plots. It has proved after some experience that they afford little embarrassment to the observer, since a power to overlook them and eliminate their voices from the notes of the visitant birds can be readily acquired.

White-throated, white-crowned, and fox sparrows treat the House Sparrows as inferiors and drive them at will, for they are at once recognized by them as masterful and superior.

A House Sparrow of albino type has sometimes been seen. One such of almost complete whiteness of plumage used to be seen within the Garden near the head of Newbury Street. And others in less degrees of albinism have been seen from time to time and have also been observed upon the Common. Such plumages are generally regarded as the result of degeneracy. 


\section{European GoldFinch}

Carduelis carduelis

On the morning of May'27, I908, a bird was perceived feeding on the grass near the edge of the pond, which by its coloration caused a moment of wondering surprise, for it was none other bird than a full-plumaged European Goldfinch. It permitted a somewhat near approach and was viewed by myself and my companions with the interest which attaches to a rare bird. It might have continued longer in view, had not a swan approached so near upon the waters that the little finch was frightened apparently at its immensity and whiteness, and, flying across to the trees of the island, was lost to view. The expectation was that it would be likely to be seen the next day and perhaps for several days, but it was not looked upon again and must have gone out of the Garden.

A natural presumption would be that this was an escaped cage-bird. Yet as European Goldfinches have occasionally been 


\section{EUROPEAN GOLDFINCH}

seen in the suburbs of Boston in recent years, some birds having been designedly liberated some years ago, it is quite possible that this bird was acquainted with life in nature rather than with life within a cage, and it is thus classified as a bird of the wild descended from parents which were once introduced and set free. 


\section{FOREIGN SPECIES}

\section{JAVA Sparrow}

Munia oryzivora

On October I9, I904, a bird of unusual coloration was seen picking on the ground of - the Common among a large flock of house sparrows, which proved upon investigation to be a Java Sparrow, or Java Finch. It was again seen with the flock on the following day and also on the next day. Wherever the English sparrows moved this bird went with them. It was viewed upon these three days of its presence on the slope of Monument Hill, on the level of the parade-ground, and on the lawn around the band-stand. It showed as little fear as the house sparrows, like them simply flying to a near tree when a too close approach was made by passers-by. Its call, given when taking short flights, bore a resemblance to the call of the purple finch. Otherwise it was silent. The strongly contrasting colors of 
its plumage - black, white, and slaty gray - and its stout bright-red bill made it conspicuous among its companions, and yet apparently they who passed to and fro saw it not. After the third day it disappeared.

There is no other explanation of the presence of this bird than that it had escaped from a cage and found its way to the Common.

\section{European Blackbird}

Planesticus merula

In the autumn of 1908 a foreign bird was discovered in the Garden when I made my usual round on the morning of October 9, a bird appearing essentially like our American robin in size and form, but glossy black in coloration throughout, with a bright yellow bill. The bird was none other than a European Blackbird, a male bird, doubtless escaped from captivity. It was first seen in a Norway maple by the pond, sitting quietly upon a bough, and it permitted a careful inspection of itself to be made from a position perhaps fifteen 
feet distant. One very apparent characteristic was its lifting the tail and then slowly lowering it after the manner of the hermit thrush. This, it was found, it constantly did, as it was viewed day after day thereafter. Whether the bird ran upon the ground, which it proved it much frequented, or sat upon a bough, at brief intervals this tail-action was manifested. And the tail was usually spread somewhat wider at the tip than at the base, thus presenting to some extent a fan-like form.

When on the ground it was seen to cast aside the fallen leaves with its bill in the search for food as a brown thrasher is wont to do, first on one side and then on the other. And on a few occasions there was a momentary scratching action of both feet together after the manner of a fox sparrow. When a flight was taken, it was at rather low range, and all perches were upon the lower boughs of trees; no disposition was shown to climb higher than perhaps ten feet.

On the second morning it was seen, 
namely, October Io, it was in the same tree in the southwest quarter of the grounds; for a time at first this was its chosen section, and occasionally afterwards it returned to it But later it was seen in all quarters of the Garden, most often, however, on the Beacon Street side, and after a time almost exclusively there and in that part of it which reaches up to Arlington Street. It sometimes had as a companion a robin or a hermit thrush, according as migrants of these species occasionally came to the Garden on their way southward. I recall that on one morning, when an early snow was fast falling, the Blackbird was moving about the rocks which surround the base of the large Japanese lantern near the curbing of the pond and with it were both a robin and a hermit thrush.

As the leaves continued to drop from the trees, leaving them more and more bare, the Blackbird was often seen in the English haw thorns, which still held their foliage and afforded it seclusion and protection; and it showed a fondness for a bed of salvia 
close beside the pond until in the progress of clearing up the Garden these plants were removed. In the early morning of November 6, which was clouded and frosty, our foreign visitor made use of a small pool of water upon the turf, where a hose-attachment allowed a little to flow, and refreshed himself with a bath.

Ten days later, in the early morning of November I7, the bird was found sitting on a bough of an English hawthorn which stands north of the Ether Monument, and singing sweetly in very soft tones, so soft that had I not been as near as only twenty feet away I could not have heard him. He had fully settled into the mood of singing, for he moved not upon the bough and paused not in his utterance of the sweet notes so long as I remained, which was at least ten minutes. Passers-by moved on the plank walk near the tree, but these disturbed not the bird, as he sat in the seclusion of the boughs. The song was so nearly formless that it lacked definiteness, but occasionally phrases were heard which re- 
sembled those of a wood thrush. I could not see that the bird opened its bill at all to produce its song, and I suppose it was meant for no ears to hear, either bird's or man's. This was the only occasion on which sounds were heard which were traceable to the Blackbird, unless on one other morning a "chuck" which was heard proceeded from it while I was near, and not from a possible hermit thrush which was not seen.

Usually when seen it was not seeking food actively. But several times I have seen the bird pull an angle-worm from the grass and eat it, running like a robin a few feet. upon the turf, and after a pause, in which he was plainly giving attention to his object, seizing the worm and preparing it for comfortable use by dividing it. If a house sparrow intruded at such a time, the Blackbird had only to strike out for it and the sparrow retired. On December 5 it was enjoying such a feast under a large purple beech which stands just within the Garden at the head of Marlborough Street. The ground was without frost. On December 9, 


\section{BIRDS OF THE PUBLIC GARDEN}

I I, I2, and I 5 it was seen in the Garden by several different observers, who mentioned the fact to me.

Later the bird appeared to spend most of the time in Commonwealth Avenue, as it was frequently seen near the head of the avenue by Mr. J. M. Whitaker of Cambridge between December 22 and January 26, I909, at about 8.30 in the morning. Miss E. D. Boardman informs me that she saw the bird on January 28 at the head of the avenue in a shrub in the Sears gardenborder and in the vine climbing upon the house. Mrs. Arthur T. Cabot, having gathered such accurate data as she was able concerning the wintering of this Blackbird, very kindly puts the information at my disposal. Mrs. Cabot writes me under date of February 2I: "The European Blackbird was last seen by a member of my family on Friday, February I9th, in the grass-plot of the house on the northeast corner of Berkeley Street and Commonwealth Avenue. The people in that house and in the house on the northwest corner put out crumbs for 
him, which he is said to eat. Suet, which was tied in shrubs in the vicinity, has apparently not been touched. Personally I have never seen him feeding on anything put out for him, but scratching or hunting about in the manure spread on the grass." Mrs. Cabot also states that she has seen him on Beacon Street near the Public Garden and has never heard of his being seen farther west than Berkeley Street.

This Blackbird was again seen by Mr. E. E. Caduc and me in the late afternoon of February 20 in one of the trees at the head of Commonwealth Avenue, having flown from the direction of the Garden. He placed himself snugly out of the wind in the main crotch of the tree but little above the level of our heads. I had seen him take a similar position in the Garden in December, in the first crotch of a purple beech, so narrow in width between the ascending trunks that he was almost concealed from view, and would not have been detected there had I not seen him fly to the position. Three later records of this bird have been 
kindly contributed to me by the respective observers. Miss Bertha Langmaid writes under date of February 28: "You may be interested to know that at four-thirty o'clock this afternoon I saw and heard the European Blackbird. He was in a tree in the centre of Commonwealth Avenue about halfway between Berkeley and Arlington streets and was giving a song suggesting our robin. It was not loud, but soft and very sweet, yet decided enough to attract the attention of others beside myself."

Dr. Charles W. Townsend writes: "As to the European Blackbird, I saw him on March Ist fly up from a grass-plot on Marlborough Street between Clarendon and Dartmouth streets and alight on the vines of a house. I hope some time to be awakened by his song, which will be a pleasing contrast to that of Passer domesticus." This record indicates that the bird was making use of a wider range of the Back Bay streets than had been supposed and that he was still ranging through that district when March opened. 
Mrs. Edmund Bridge writes me that she saw this Blackbird singing beautifully on March 8 at 9.I 5 in the morning in a maple tree in Commonwealth Avenue between Arlington and Berkeley streets, the section of the avenue which he has most frequented. Mrs. Bridge states that the bird was perching in the curve of one limb partly covered by another and that the singing might be likened to the mockingbird's song.

Ten days later, on March 18 , this Blackbird was found by me to be again within the Garden. The water of the pond had just been drawn off for the annual cleaning out of litter, leaving the bottom exposed, and here the Blackbird was busily feeding, accompanied by one of two early-arrived robins. He moved freely about over a portion of the surface, and his motions indicated that he found it good feeding-ground, for he was constantly picking up and swallowing bits of food which the draining off of the water had brought to view. What these bits were I could not discern. The following morning he was again seen and was simi- 
larly occupied, and so each succeeding morning up to March 25, when his record for this volume was necessarily closed. On three of these mornings, March 20, 24, and 25, at about seven o'clock, he sang a few phrases of song in mellow, rich tones, which were thrushlike in quality and suggested at times, now the bluebird's song and again the wood thrush's, but sang softly, not allowing his voice free scope, and each time he all too quickly dropped to the ground again to feed, and the brief singing was ended. On all of these mornings the temperature was near, or several degrees below, the freezing point and the surface was hard frozen. These conditions probably did not move him to sing freely, and so for hearing the full power and beauty of his voice we must doubtless await higher temperatures and more springlike conditions. The eight days of continuous stay, following his return to the Garden, indicates that this foreign visitor, after three months' winter residence in Commonwealth Avenue, has once more established himself in the Public Garden 


\section{EUROPEAN BLACKBIRD}

amid favorable conditions with a full, long season before him in which to enjoy himself and furnish interest and enjoyment to the Boston public。 



\section{INDEX}

Norz. - The heavy-faced type indicates the place where the species is treated at length.

Acanthis linaria, 100.

Accipiter velox, 62.

Actitis macularia, 6r.

Agelaius phœniceus, 89.

Albinism, 2I 5 .

Allen, Francis H., $\mathbf{x}, 63,65,69$, 7 I, 98, I39, I8 5 .

Allen, Glover M., $\mathrm{x}, \mathrm{xi}, 74,87$, IоO.

Anthus rubescens, $\mathrm{I} 8 \mathrm{I}$.

Arlington Street, 7, 50, 73, 163 , I6g, I70, I73, 202, 22 I, 226, 227.

Arlington Street Church, I52, I63, I69.

Astragalinus tristis, ror.

Attachment to location, 49-5I, I49, I6 3, I70, 203.

Aviary, 6, 27.

Back Bay district, 5, 62, 67, 75, 76, 226.

Bath, II 3, I5O, 2I5, 222.

Beacon Hill, 75 .

Beacon Street, 4, 7, 59, 65, 74, 83, I33, I70, I 9 I, 202, 22 I, 225.

Beech, European, I48, I77, I93, 200.

Beech, purple, 95, 223, 225 .

Beeches, 8, I 12, І70, I73, I96.

Berkeley Street, 224-227.
Birches, 8.

Blackbird, Crow, 93.

Blackbird, European, 2 I9.

Blackbird, Red-winged, 33, 34, 89,96 .

Blackbird, Rusty, 92.

Black-cap, Wilson's, I 77.

Blake, Maurice C., xi, 92, I I2, I20, I39, I6I, I72, I88, I98. Bluebird, I9, 23, 32, 96, 209, 228.

Boardman, Miss E. D., 224.

Bobolink, 33, 34, 85 .

Bob-white, 62.

Bombycilla cedrorum, I38.

Botanic Garden, 3.

Boylston Street, 7, 8, I52, I6o.

Bradlee, Thomas S., I76.

Branta canadensis, 58.

Brewster, William, $x, x i, 2 \pi-23$, $67,83,99,212$.

Bridge, Mrs. Edmund E., 227.

Brimmer Street, 84.

Butcher-bird, I39.

Buteo platypterus, 63.

Buteos, 63.

Cabot, Mrs. Arthur T., 224, 225.

Caduc, Eugene E., $x, 66,69,74$, $75,78,82,85$, I4I, I89, 225.

Cage-birds, 54, 2I6, 219. 
Carduelis carduelis, 2 I6.

Carpodacus purpureus, 99.

Catbird, I3, 23, 28-30, 32, 33, $35,38,39,63, I 8 I, 183$.

Cats, Io.

Cedar-bird, I3 $_{3} 8$.

Census, I3, I4, I7, 40.

Certhia familiaris americana, I 86.

Ceryle alcyon, 69.

Chadbourne, Dr. Arthur P., 67.

Chetura pelagica, 76.

Chapman, Frank M., I46.

Charles River, 44, 58 .

Charles River Basin, 57, 58 .

Charles Street, 4, 7, 59, 65, 84, I4I.

Chat, Yellow-breasted, $x_{3}, 28$, 29, 32, 38, I59, I75.

Chebec, 8I.

Chestnut Street, 37.

Chewink, I3I.

Chickadee, I5, I89, I90, I9I.

Chippy, II4.

Chordeiles virginianus, 75 .

City Hall, $87,88$.

Clangula clangula americana, 58.

Clarendon Street, 70, 226.

Coccyzis americanus, 67.

Coccyzus erythrophthalmus, 68.

Coffee-tree, Kentucky, 52.

Colaptes auratus luteus, 73.

Colinus virginianus, 62.

Common, Boston, 5, 7, II, 20, $23,24,36,37,44,46,53,65$, 66, 70, 7I, 73-75, 78, 79, 84, $85,87,9$ I, 93, 94, I04-IO7, IIO, II 3 , II5-II9, I II, I22,

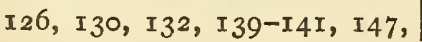

I49, I 55, I 56, I 58, I65, I67, I69, I75, I78, I80, I86, I88, I9I, I96, 20I, 202, 206, 2 I0$212,215,218,219$.

Commonwealth Avenue, 62, $64,67,189,224-228$.

Compsothlypis americana usnea, I48.

Continuance of stay, $6,19,26$, 32, 36, 49-51.

Corvus brachyrhynchos, 83 .

Cowbird, 86.

Creeper, Black and White, I43,

Creeper, Brown, I3, I86, I88, I89.

Creeper, Pine, I66.

Crossbill, White-winged, roo.

Crow, American, 83 .

Cuckoo, Black-billed, 68.

Cuckoo, Yellow-billed, 35, 67 .

Cyanocitta cristata, $\mathbf{8 2}$.

Dartmouth Street, 226.

Day, Chester S., 74.

Dendroica astiva, I53.

Dendroica blackburnia, I62.

Dendroica carulescens, I 54.

Dendroica castanea, I58.

Dendroica coronata, I55.

Dendroica discolor, I68.

Dendroica magnolia, $\mathbf{5} 6$.

Dendroica palmarum, I66.

Dendroica palmarum hypochry. sea, 167 .

Dendroica pensylvanica, I57.

Dendroica striata, $\mathbf{5} 5$.

Dendroica tigrina, I49.

Dendroica vigorsii, 166.

Dendroica virens, 164 .

Dolichonyx oryzivorus, 85 . 
Dryobates pubescens medianus, |Glaux acadicus, 65.

$7 \mathrm{I}$.

Dryobates villosus, 70.

Dumetella carolinensis, I8I.

Elm, American, 7, 8, 63, 65, $90,9 \mathrm{r}, \mathrm{I} 30, \mathrm{I} 33, \mathrm{I}_{52}, \mathrm{I}_{3}$, I 9 r.

Elm, Dutch, 8.

Elm, English, 7, 8, 147,163 , I68.

Emerson, Guy, xi.

Empidonax flaviventris, 80 .

Empidonax minimus, 8I.

Euphagus carolinus, 92.

Falco sparverius, 64.

Falcons, 63 .

Female birds, 48.

Fens, $64,85,89,90$, I40.

Finch, Grass, I03.

Finch, Java, 2 I8.

Finch, Pine, I02.

Finch, Purple, 30, 33, 35, 37,

$63,99, \mathrm{x} 24,2 \mathrm{I} 8$.

Flicker, Northern, 24, 32, 33, 47,73 .

Flycatcher, Least, 22, 24, 28, 3r,

$33,35,37,39,8$ I.

Flycatcher, Yellow-bellied, 39, 80.

Flycatchers, 82, 152, I94.

Foreign species, 54, 2I8, 219 .

Frog Pond, 7, 67, 70.

George, Miss Isabel P., $\mathrm{x}, \mathrm{I} 45$, I95.

Geothlypis trichas, I74.

Gilbert, R. A., 67 .

Gingko tree, 64 .
Gnatcatcher, Blue-gray, 193.

Golden-eye, American, 53, 58.

Goldfinch, American, 39, IoI.

Goldfinch, European, 216.

Goose, Canada, 58.

Goshawk, 63 .

Grackle, Bronzed, 24, 25, 47, $48,63,93,98$, I 20, I 21, I 98 , 205, 206, 2 I 3 .

Grackle, Purple, 96 .

Granary Burying-Ground, 53, $69,99,185$.

Gray, Horace, 3, 4.

Grosbeak, Pine, 98.

Grosbeak, Rose-breasted, 3r, $32,37, I 32$.

Gull, Herring, 57.

Hangbird, 90.

Hardy, John H., Jr., x, 65 .

Hawk, American Sparrow, 64.

Hawk, Broad-winged, 63.

Hawk, Sharp-shinned, 62.

Hawthorn, English, 94, ${ }_{7} 7$, I84, 22 I, 222.

Helminthophila chrysoptera, 146.

Helminthophila peregrina, I47.

Helminthophila rubricapilla,

I 46.

Helodromas solitarius, 60.

Heron, Black-crowned Night,

59.

Hirundo erythrogaster, I36.

Horticulture of Boston, 3 .

Hummingbird, Ruby-throated, $39,77$.

Hunt, David, Jr., 58.

Hylocichla alicia, I97. 
Hylocichla alicia bicknelli, 198 . Hylocichla fuscescens, I95. Hylocichla guttata pallasii, 200. Hylocichla mustelina, I94. Hylocichla ustulata swainsoni, I99.

Icteria virens, $\mathbf{1 7 5}$.

Icterus galbula, 90.

Introduced species, 52, 54, 212, 217.

Iridoprocne bicolor, $\mathrm{I}_{3} 6$.

Island, 73, II 3, I 34, I66, 2 I6.

Jay, Blue, 33-35, 63, 82 .

Joy Street path, 66, 74 .

Junco hyemalis, I I 8.

Junco, Slate-colored, 47, I I8, I27.

\section{King's Chapel Burying-} Ground, 87.

Kingbird, 22, 31, 35, 78.

Kingfisher, Belted, 53, 69.

Kinglet, Golden-crowned, I89, I9I, I93.

Kinglet, Ruby-crowned, I3, 192, 193 .

Lamps, city, 18, I9, II4. Langmaid, Miss Bertha, 226. Lanius borealis, I39.

Lanivireo flavifrons, 142.

Lanivireo solitarius, I43.

Larus argentatus, 57.

Lincoln, Frederic Walker, Jr., 5.

Linden, European, 8, 66.

Louisburg Square, 37, 84, I30. Loxia leucoptera, I00.
Male birds, 48, 49, 5 I.

Maple, Norway, 2I9, 22 I.

Maple, Silver, 50, I63.

Maple, Sycamore, I6I, I73, I94.

Maples, 7, 8, 69, 163 .

Marlborough Street, 67, 70, $223,226$.

Melospiza georgiana, 124 .

Melospiza lincolnii, I23.

Melospiza melodia, I 20.

Migration, 6, I2, I4-2r, 25-27, $27.29,33,35,36,38,40,42$, $43,45,48$.

Migratory flights, large, 25, $27-$ $34,36,38-40,45,46$.

Mniotilta varia, I43.

Mockingbird's song, 227. Molothrus ater, 86.

Monument Hill, 7, 37, 75, I04, 105, I16, I88, 2 10, 2 I 8.

Morning, early, I $5^{-1} 7,59$.

Mt. Vernon Street, 37 .

Munia oryzivora, 2 I8.

Myiochanes virens, 79 .

Nannus hiemalis, 185 .

Nesting, 20, 23-25, 73, 74, $76,83,91,92,94,96$, 122, I4I, I42, I53, I80, 205, 207, 210.

Newbury Street, I68, 2 I 5 .

Night Heron, Black-crowned, 59.

Nighthawk, 39, 75 .

Nuthatch, Red-breasted, I 88. Nuthatch, White-breasted, I88.

Nycticorax nycticorax nevius, 59. 
Oporornis agilis, $\mathbf{1 7 3}$.

Oriole, Baltimore, 24, 25, 90, I $34,205$.

Otus asio, 66.

Oven-bird, I3, 23, 28, 30, 35, $33,34,38,39,50$, I 68, I 7 I, I 72.

Owl, Acadian, 65.

Owl, Barred, 53, 63, 65.

Owl, Saw-whet, 53, 65 .

Owl, Screech, 66.

Parade-ground, 104, 218.

Park Square, 210.

Park Street station, 53 .

Passer domesticus, 2I2, 226.

Passerculus sandwichensis savanna, I04.

Passerella iliaca, I 26.

Peabody-bird, I Io.

Peach tree, double-flowered, I 5 I.

Penthestes atricapillus, I90.

Petrochelidon lunifrons, 135 .

Pewee, Wood, 28, 3I, 35, 39,

79.

Philohela minor, 59.

Phœbe, 22. 78, I66.

Pigeons, 52.

Pinckney Street, 204.

Pinicola enucleator leucura, 98.

Pipilo erythrophthalmus, I3I.

Pipit, American, I8I.

Piranga erythromelas, I33.

Planesticus merula. 2 I 9.

Planesticus migratorius, 205.

Polioptila carulea, I93.

Pond, 9.

Poocetes gramineus, I03.

Poplar, White, 8, I60.
Potter, F. B., 67, I89.

Protonotaria citrea, I45.

Purdie, H. A., xi, 83 .

Puritan Club, 84.

Quiscalus quiscula aneus, 93.

Rainy weather, I2, 26-28, 35 .

Rand, Dr. Manning K., x, 73,

74, I45.

Redpoll, I00.

Redstart, American, 23, 24, 28,

$29,32,33,35,38,39$, I80.

Regulus calendula, I92.

Regulus satrapa, I9I.

Rhododendrons, 98, I 29, I48, I 82.

Riparia riparia, I37.

Robin, American, I9, 24, 25, $47,48,98$, I 20, I21, I28, I66, 205, 219, 22I, 223, 226, 227.

Sandpiper, Solitary, I9, 60. Sandpiper, Spotted, I9, 6r.

Sapsucker, Yellow-bellied, 72.

Sayornis phobe, 78.

Season, opening of, 47.

Seasons, comparison of, 4I45.

Seiurus aurocapillus, 168.

Seiurus noveboracensis, I7I.

Setophaga ruticilla, $\mathbf{1} 80$.

Shrike, Northern, I39.

Shrubs, 9.

Sialia sialis, 209.

Siskin, Pine, 37, 102.

Sitta canadensis, I 88 .

Sitta carolinensis, 188.

Snow, 48, 95, II4, I20, I28, 22 I. 
Snowbird, II8.

Somerset Club, 83.

Song, I6, 45, 5I, 52 .

Spalding, F. P., xi, 87, 88.

Sparrow, Chipping, 22, 37,

I I4, I6I.

Sparrow, English, I40, 2I2, 218.

Sparrow, Field, 3I, 33, I I6. Sparrow, Fox, 87, II9, I26, 206, 2 I 5, 220.

Sparrow, Ground, I20.

Sparrow, House, Io, I6, 87, 88, 9I, IO9, II 3, I $40,2 I 2,2 I 8$, $223,226$.

Sparrow, Java, 2 I8.

Sparrow, Lincoln's, 13, 28-30, $35,37, \mathbf{2} 3$.

Sparrow, Savanna, 20, 33, I04. Sparrow, Song, 20, 30, 47, 48, 87, I 20, I 24, I 27, 206.

Sparrow, Swamp, 20, 28-3I, 33,

37,87, I 24, I66.

Sparrow, Tree, II3.

Sparrow, Vesper, 22, 87, I03, I05.

Sparrow, White-crowned, 3I, 37, I07, 2 I 5.

Sparrow, White-throated, I3, $28,30-33,35,37$, I IO, 2 I 5 .

Sparrows, 20, 2I , 34, 37, 39, 82, I04, I30.

Sphyrapicus varius, 72.

Spinus pinus, I02.

Spizella monticola, I I3.

Spizella passerina, II4.

Spizella pusilla, I I6.

Spring, awakening of, I2 I .

Spruce Street, 66, 84.

State House, 5.
Strix varia, 05.

Summer residents, 20-25, 52, $74,76,83,90,93,97$, 工 30 , I $4 \mathrm{I}, 205$.

Swallow, Bank, 3I, I37.

Swallow, Barn, 28, 3I, I35, I36, I37.

Swallow, Cliff, 3I, I 35, I 37 .

Swallow, Eave, I 35 .

Swallow, Tree, I36, I37.

Swallow, White-bellied, I36.

Swallows, I35, I37.

Swan, European, 52, 216.

Swift, Chimney, 28-33, 35, 76.

Tanager, Scarlet, 23, 28, 29,

3 I, 32, 35, 39, I 33, I 59 .

Thistle-bird, I or.

Thrasher, Brown, 13, 23, 30,

$33,35,38,50,183,220$.

Thrush, Alice's, I97.

Thrush, Bicknell's, I97, I98.

Thrush, Golden-crowned, I68.

Thrush, Gray-cheeked, 28, 29, 39, 197.

Thrush, Hermit, 2 I, 33, 34, 38, $47,50,87$, I 66, I95, 200, 220, 22 I, 223 .

Thrush, Olive-backed, I3, 28 , $3^{\mathrm{I}-33}, 35,38,39$, I98, I99. Thrush, Swainson's, I99.

Thrush, Wilson's, 28, 30-33, $35,38,39$, I 95 .

Thrush, Wood, 33, 34, I94, 223, 228.

Thrushes, I 2, 2I, I95, I97, 200, 228.

Titlark, I8I.

Torrey, Bradford, $x$-xii, II , 24, 44, 59, 60, 65, 69, 86, 93 . 
Towhee, $13,22,30,33,35,37$, I3I.

Townsend, Dr. Charles W., $\mathrm{x}, \mathrm{xi}, 60,62,70,97$, I I4, I39, I $76,183,198,201,209,226$.

Townsend, Mrs. C. W., 96.

Toxostoma rufum, $\mathbf{I} 83$.

Trees, 7,-9, 44.

Tremont Street mall, 65 .

Trochilus colubris, 77.

Troglodytes aëdon, $\mathbf{1} 85$.

Tyrannus tyrannus, 78.

Union Club, 67.

Veery, I95.

Vireo, Blue-headed, 3I, 35, I 43 .

Vireo, Red-eyed, 23, 24, 28, 3I, $35,39, \mathrm{I} 40, \mathrm{I} 4 \mathrm{I}$.

Vireo, Solitary, I43.

Vireo, Warbling, 23, 24, 28, 29, 32, I 4 , I 42 .

Vireo, Yellow-throated, 3I, I 42.

Vireosylva gilva, I42.

Vireosylva olivacea, I40.

Warbler, Bay-breasted, 29, I 58 .

Warbler, Black and White, 23 , $28,30,3 \mathrm{I}, 33,34,37, \mathbf{I} 43$.

Warbler, Black and Yellow, I 56.

Warbler, Blackburnian, 28, 29, $32,34,3^{8}, 39,50$, I 59, I 60 , I62.

Warbler, Black-poll, 28-32, 34,

39 , I 59, I6 3 , I 73, I94. Warbler, Black-throated Blue, Warbler, Yellow-rumped, I 55.
$28,29,3$ I, 32, 34, 37, 39, I54, I6 3 .

Warbler, Black-throated Green, 23, 30, 3I, 33, 34, 39, I63, I64.

Warbler, Blue Yellow-backed, I 48.

Warbler, Canadian, 28-30, 32, 33,39, I64, I79.

Warbler, Cape May, 49, 50, I49.

Warbler, Chestnut-sided, 23 , Warbler, Connecticut, I73, I 75 .

Warbler, Golden-winged, 28 , I46.

Warbler, Magnolia, 28-34, 37, 39, I 56, I6 3 .

Warbler, Myrtle, 30-34, 37, 39, I 55, I 56.

Warbler, Nashville, 23, 30, 3I, $33,34,146$.

Warbler, Palm, I 66.

Warbler, Parula, 28-34, 37, 39,

I 48, I 75.

Warbler, Pine, I 66.

Warbler, Prairie, 29, I68.

Warbler, Prothonotary, I45.

Warbler, Redpoll, I 66.

Warbler, Tennessee, 3I, 39,

I 47.

Warbler, Wilson's, 28-30, 32,

$33,35,38,39$, I 77, I79.

Warbler, Yellow, 23, 28, 29, 31-

$34,37,39, \mathbf{I} 53$.

Warbler, Yellow Palm, ı66, I 67.

Warbler, Yellow Redpoll, I67. $28,29,3$ I-34, 39, I 57, I63. 
Warblers, 10, I2, 20, 21, 28-34, |Winter visitants, $16,66,67,7 \mathrm{I}$, $36-40,44,48,63,82$, I 46 , I 59, I $63, I 64, I 75$, I 76, I 80 , $2 \mathrm{I} 4$. $74,75,98$-IOI, I I 4, I 40, I 83 , I89, 209 .

Water-thrush, Northern, I3, 28-3 I, 33, 34, 38, 39, I 7 I.

Waxwing, Cedar, 19,138 .

Weather, I 2, I3, 25-28, 32, 35, $37,39,42,48$.

Wellman, Gordon Boit, xii.

Whitaker, J. M., 224.

White Mountains, I I, 200, 204.

Whitney, Miss Calista S., I45.

Wilder, Marshall Pinckney, 3 .

Willow, old, I52, I63.

Willow, White, 68, I 5 I.

Willows, 8, 73, 92, I 45, I 52 , I 59, I60, I63.

Wilsonia canadensis, I79.

Wilsonia pusilla, I77.

Winsor, Justin, xi.

Winter residents, I 5, 57, 58, 64, 87, 100, 190, 224.

Winter Street path, 66

Woodcock, American, 53, 59.

Woodpecker, Downy, 7I, 72, I6I.

Woodpecker, Golden-winged, 73.

Woodpecker, Hairy, 70, 188. Woodpecker, Yellow-bellied, 72.

Woodpeckers, 25 .

Wren, House, 33, 34, 185 .

Wren, Winter, 53,185 .

Wright, Miss Mary A., I95.

Yellow-bird, Summer, I53.

Yellow-hammer, 73.

Yellow-throat, Maryland, 23, $28-30,32,33,35,38,39$, I 74 .

Zamelodia ludoviciana, $\mathbf{1 3 2}$.

Zonotrichia albicollis, I IO.

Zonotrichia leucophrys, 107. 

